\title{
Geology and Ground Water in the Farmington-Granby Area Connecticut
}

GEOLOGICAL SURVEY WATER-SUPPLY PAPER 1661

Prepared in cooperation with the Connecticut Water Resources Commission

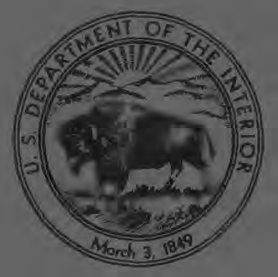




\section{Geology and Ground Water in the Farmington-Granby Area Connecticut}

By ALLAN D. RANDALL

G.E OLOGICAL SURVEY WATER-SUPPLY PAPER 1661

Prepared in cooperation with the Connecticut Water Resources Commission

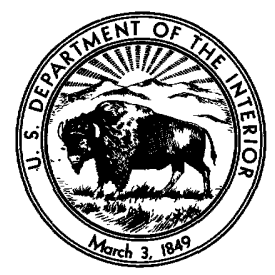




\title{
UNITED STATES DEPARTMENT OF THE INTERIOR
}

\author{
STEWART L. UDALL, Secretary
}

\section{GEOLOGICAL SURVEY}

Thomas B. Nolan, Director

The U.S. Geologica1 Survey Library catalog card for this publication appears after page 129 . 


\section{CONTENTS}

Abstract

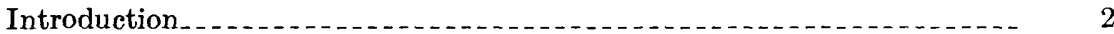

Purpose and scope of investigation........... 2

Location and areal extent. 3

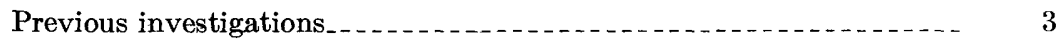

Methods of investigation .

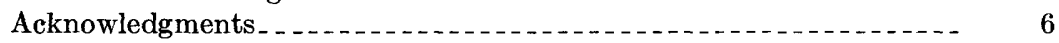

Well-numbering system $\ldots \ldots \ldots$

Map-location system 7

Geography

Physiography and drainage

Climate................ 11

Population 13

Geology

Geologic units........ 14

Geologic history

Preglacial history

Glaciation ........... 16

Deglaciation . .

Postglacial history ...

Physical characteristies and water-yielding properties of the geologic units_- $\quad 19$

Consolidated rocks

Crystalline rocks of pre-Triassic age $\ldots \ldots$

Areal distribution and thickness . . . 20

Lithology

Stratigraphic relations

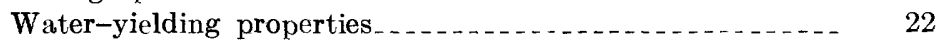

Newark group

Areal distribution and thickness

Lithology _...

Stratigraphic relations..... 31

Water-yielding properties. 31

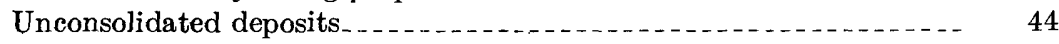

Ground-moraine and drumlin deposits.................. 44

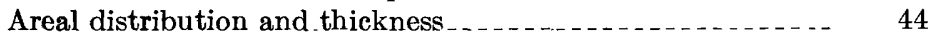

Lithology

Stratigraphic relations......

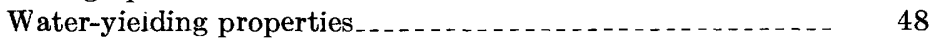

Ice-contact deposits

Areal distribution and thickness $\ldots$

Lithology _................. 51

Stratigraphic relations_._._.

Water-yielding properties._... 56

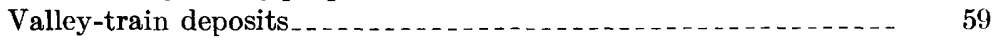

Areal distribution and thickness_..

Lithology _...

Stratigraphic relations_..._.

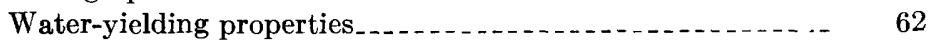


Physical characteristics and water-yielding properties, etc.--Continued

Consolidated rocks-Continued

Alluvial deposits

Areal distribution and thickness $\ldots \ldots \ldots$

Lithology

Water-yielding properties.

Ground water

Ground-water availability in the stratified drift and alluvial

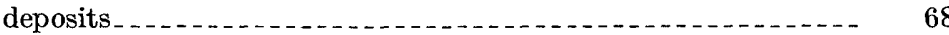

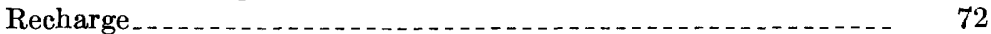

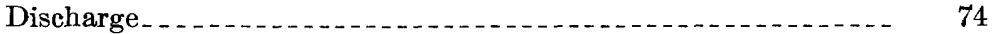

Use of ground water.

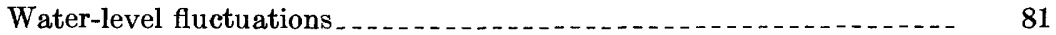

Natural fluctuations. . . .

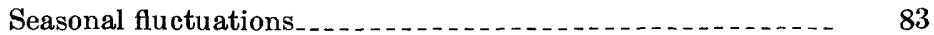

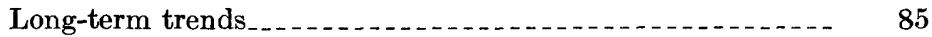

Maximum range of fluctuation

Effect of geology and topography

Fluctuations due to pumping .

Types of wells and springs... 90

Drilled wells . .

Jetted wells........... 91

Driven wells . . . .

Dug wells $\ldots$

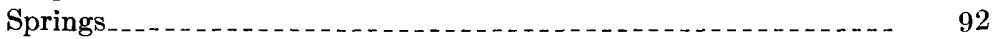

Quality of ground water.

Chemical characteristics of ground water.

Quality as related to source

Quality as it influences use ............................. 103

Bacterial contamination in ground water . . . . 104

Temperature of ground water... 108

Logs of wells and test borings

Selected references...

Index.

\section{ILLUSTRATIONS}

[Plates are in separate volume]

Plate 1. Bedrock topography and surficial geology of the FarmingtonGranby area.

2. Geologic cross sections.

3. Ground-water availability in the stratified drift and alluvial deposits of the Farmington-Granby area.

FigURE 1. Index map of Connecticut, showing area of this report, towns, and status of ground-water investigations

2. Areas in Connecticut covered by U.S. Geological Survey watersupply papers referring to ground water and published prior to 1930 
4. Physiographic divisions and drainage in and near the Farmington-Granby area

5. Outcrop of crystalline rock, showing ice formed when ground water issued from joint openings in the rock during winter months.

6. Outcrop of igneous rock of the Newark group, showing welldeveloped vertical and horizontal joints .

7. Depths of domestic and farm wells finished in the Newark

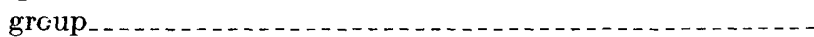

8. Rock thicknesses penetrated by domestic and farm wells

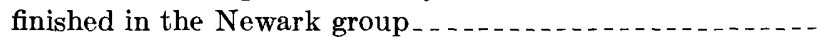

9. Glaciofluvial beds in the ice-contact deposits.........

10. Lower unit of the valley-train deposits .......................

11. Cross section through wells EG 33 and 36, showing water levels and topography in a part of East Granby .......

12. Total discharge and estimated ground-water discharge of Salmon Brook at Granbrook Park from October 1949 through September 1950_.....

13. Water-level fluctuations in four observation wells finished in unconsolidated deposits...........................

14. Water-level fluctuations in eight observation wells finished in the Newark group.

15. Diagrammatic section of a well that is being pumped, showing its drawdown, cone of depression, and area of influence...-

16. Hydrograph of water levels in well EG 33 from October 17 through October 25, 1957. Measurements were made by an automatic recorder

17. Diagrammatic representation of the chemical character of ground water in the Farmington-Granby area..........

18. Fluctuations of ground-water temperatures

\section{TABLES}

TABLE 1. Normal monthly precipitation

2. Summary of climatological data at Hartford, Conn .........

3. Evaporation at Reservoir No. 1, West Hartford, Conn .......

4. Area and population of towns in the Farmington-Granby area.-

5. Geologic units in the Farmington-Granby area

6. Records of drilled wells involved in pumping tests..........

7. Estimated use of ground water for public water-supply systems during 1957

8. Estimated use of ground water for private domestic water supplies during 1957

9. Estimated total use of ground water in 1957 in the FarmingtonGranby area, by. categories of use . . . . . . . . . . . . .

10. Estimated total ground-water use in 1957 in the FarmingtonGranby area, by towns

11. Records of selected observation wells in the FarmingtonGranby area 
12. Records of selected springs in the Farmington-Granby area...

13. Chemical analyses of water from wells and springs in the Farmington-Granby area ...........................

14. Significance, recommended limits, and concentration of various constituents in ground water in the Farmington-Granby

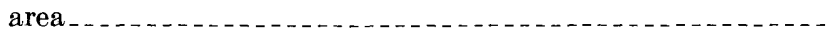

15. Detailed logs of wells and test borings in the Farmington-

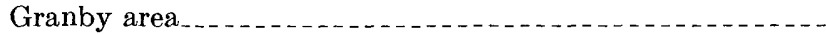

16. Brief logs of wells in the Farmington-Granby area 


\title{
GEOLOGY AND GROUND WATER IN THE FARMINGTON- GRANBY AREA, GONNECTICUT
}

\author{
By Allan D. Randall
}

\begin{abstract}
The Farmington-Granby area consists of the towns of Farmington, Avon, Simsbury, and Granby, plus the parts of East Granby and Suffield that lie west of the crest of the principal trap ridge in these towns.

The bedrock of the Farmington-Granby area includes pre-Triassic crystalline rocks, and sedimentary and igneous rocks of Triassic age. Overlying the bedrock in most places is a mantle of ground moraine and drumlin deposits, both composed largely of glacial till. Parts of the till and bedrock are overlain by stratified glacial drift consisting of ice-contact and valley-train deposits. The youngest deposit is the stream alluvium of Recent age.

Crystalline rocks include the Collinsville gneiss of Rodgers and others (1956) and the Hartland formation; they are present only near the western margin of the Farmington-Granby area. The median yield of domestic and farm wells is $9 \mathrm{gpm}$ (gallons per minute) in the Hartland formation and $5 \mathrm{gpm}$ in the Collinsville gneiss. The crystalline rocks are a little less promising source of water for domestic and farm wells than the Triassic sedimentary and igneous rocks, and they may be a substantially less promising source for commercial or industrial supplies.
\end{abstract}

Sedimentary and igneous rocks of the Newark group of Triassic age underlie most of the Farmington-Granby area. Only $71 \frac{1}{2}$ percent of the wells in the Newark group are reported to yield less than $3 \mathrm{gpm}$. On the average, yields of 25 to $35 \mathrm{gpm}$ are fairly readily obtainable from bedroek of the Newark group, and $100 \mathrm{gpm}$ can generally be obtained from wells 300 to 600 feet deep. A yield of more than $150 \mathrm{gpm}$ would be unusual, and a yield of more than $600 \mathrm{gpm}$ would be very unlikely.

Ground-moraine deposits are widespread but generally less than 30 feet thick, whereas drumlin deposits are much thicker. They are almost entirely composed of glacial till; which is relatively impermeable and yields little or no water to drilled or driven wells; however, large-diameter dug wells in till can provide small domestic or farm supplies.

Ice-contaet deposits, the most widespread type of stratified drift, consist largely of sand but contain some gravel and a little silt : many beds are at least as coarse as medium sand. :They yield the largest water supplies of any of the geologic units in the Farmington-Granby area, although variations in lithology and thickness locally limit their potential yield. The maximum reported yield was $1,200 \mathrm{gpm}$. The specific capacity of 7 public-supply, industrial, and irrigation wells ranged from 46 to $5 \mathrm{gpm}$ per foot. 
The valley-train deposits consist chiefly of fine sand, very fine sand, and silt, except for pebbly medium to coarse sand in the upper 5 to 40 feet. Wateryielding properties are generally unfavorable below this surface layer, though scattered coarse channel deposits are included at depth in Farmington, southern Avon, and Suffield.

Alluvial deposits reach significant thicknesses chiefly along the major streams. They are generally coarse and permeable along the Farmington River upstream from Farmington center, and along Salmon Brook upstream from Granbrook Park.

Nearly all the ground water in the Farmington-Granby area is derived from local precipitation. The normal annual rainfall is equivalent to 107 billion gallons of water per year over the 142-square-mile report area. It appears that about 25 percent of the precipitation in the area becomes direct runoff; about 31 percent percolates downward to the water table; and the remaining 44 percent is returned to the atmosphere by evapotranspiration. An estimated 900 million gallons of ground water was pumped in 1957 in the report area.

Water levels in wells are normally highest in March, April, or May and lowest in October or November, but unusual rainfall distribution can alter this seasonal pattern. No long-term rise or decline of the water table is evident from available records. Water levels in one observation well tapping bedrock showed daily fluctuations of no more than 2.39 feet, owing to pumping of nearby domestic wells.

Bicarbonate is the dominant anion in most ground water in the FarmingtonGranby area, and calcium the dominant cation. Water from the Newark group is harder and contains a larger concentration of most chemical constituents than water from crystalline rock or stratified drift. The pH of most water from the Newark group is 7.0 or higher, whereas the $\mathrm{pH}$ of most water from the other aquifers is 7.0 or below. The only constituents present in many wells in concentrations greater than the recommended limits for drinking and culinary uses are iron and manganese, and nitrate.

The average temperature of ground water is about $50^{\circ} \mathrm{F}$. The temperature at shallow depths fluctuates seasonally, but below 60 feet these fluctuations are very small.

\section{INTRODUCTION}

\section{PURPOSE AND SCOPE OF INVESTIGATION}

The Farmington-Granby area, like other areas near Hartford, has grown rapidly since 1945, and extensive suburban construction and some industrial development have taken place. A large proportion of the water used in 1959 was ground water, and greater ground-water development will be needed in the future to supply water requirements for the expected continued growth of the area. To obtain information on the availability of ground water within the Farmington-Granby area, a moderately detailed areal study was begun in the summer of 1953 by the U.S. Geological Survey, in cooperation with the Connecticut Water Resources Commission. This investigation, which is part of a continuing program for the collection and interpretation of basic data on the occurrence of ground water in Connecticut, was under the direct supervision of R. V. Cushman, geologist-in-charge, Middletown, 
Connecticut subdistrict office. H. E. Simpson and R. W. Schnabel of the Geological Survey, who mapped the New Britain and Avon quadrangles, respectively, suggested several improvements in the geologic map which the writer had previously made.

\section{LOCATION AND AREAL EXTENT}

The Farmington-Granby area occupies about 142 square miles in the western part of Hartford County, Conn. It comprises the towns of Farmington, Avon, Simsbury, and Granby, and the parts of the towns of East Granby and Suffield that lie west of the trap ridge known as Hatchett Hill, Peak Mountain, and West Suffield Mountain. Within each of these towns are several small but expanding community centers or developed areas; Simsbury, for example, includes Simsbury center, Weatogue, West Simsbury, and Tariffville. The location of the Farmington-Granby area, and of other areas in which ground-water investigations have been made under the Connecticut cooperative program, are shown in figure 1 .

\section{PREVIOUS INVESTIGATIONS}

The only previous studies of ground water in the FarmingtonGranby area were made many years prior to this investigation. Three water-supply papers of the U.S. Geological Survey published during the first quarter of this century contain information pertaining to parts or all of the Farmington-Granby area. The earliest of these (Gregory, 1909) describes the ground-water resources of the entire State and contains a study by E. E. Ellis on the occurrence of water in crystalline rocks. Two moderately detailed reports by H. S. Palmer $(1920,1921)$ contain general information on occurrence of ground water; they contain also brief descriptions of the geography, water-yielding formations, and water quality in each of 31 Connecticut towns, including all the towns in the Farmington-Granby area. Palmer's reports were published at a time when most rural water supplies were obtained from dug wells. His reports provide information on this type of well that is still helpful, including records of many dug wells in each town, chemical analyses of water from several of them, and a discussion of well yields. Altogether, seven water-supply papers describing specific parts of Connecticut were published prior to 1930 ; the area covered by each is shown in figure 2 .

From October 1934 through October 1939, weekly water-level measurements were made in several wells in the towns of Farmington, Avon, Simsbury, and Suffield by the Connecticut Ground Water Survey, a project of the Works Progress Administration in cooperation with the Connecticut State Water Commission and under the direc- 


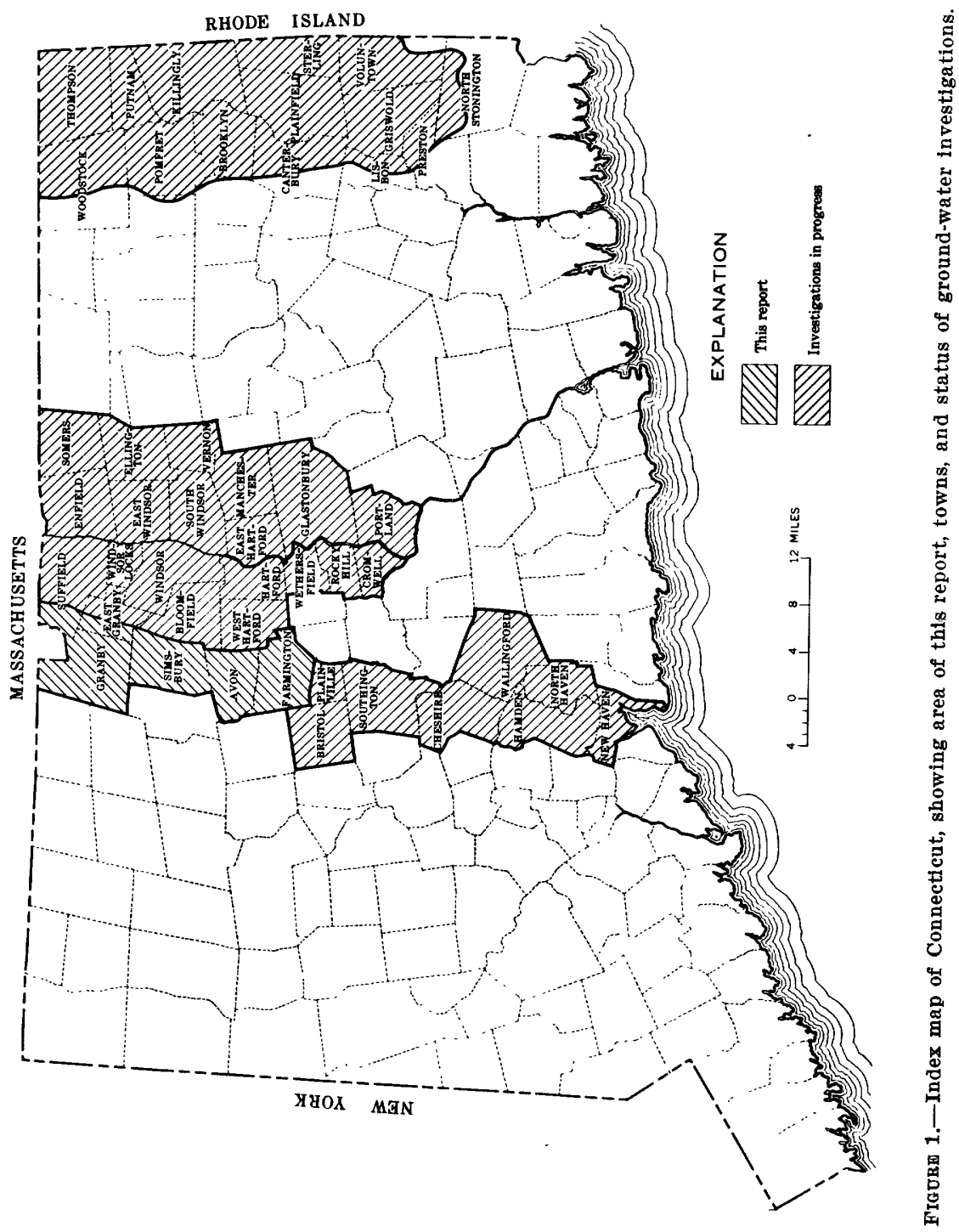




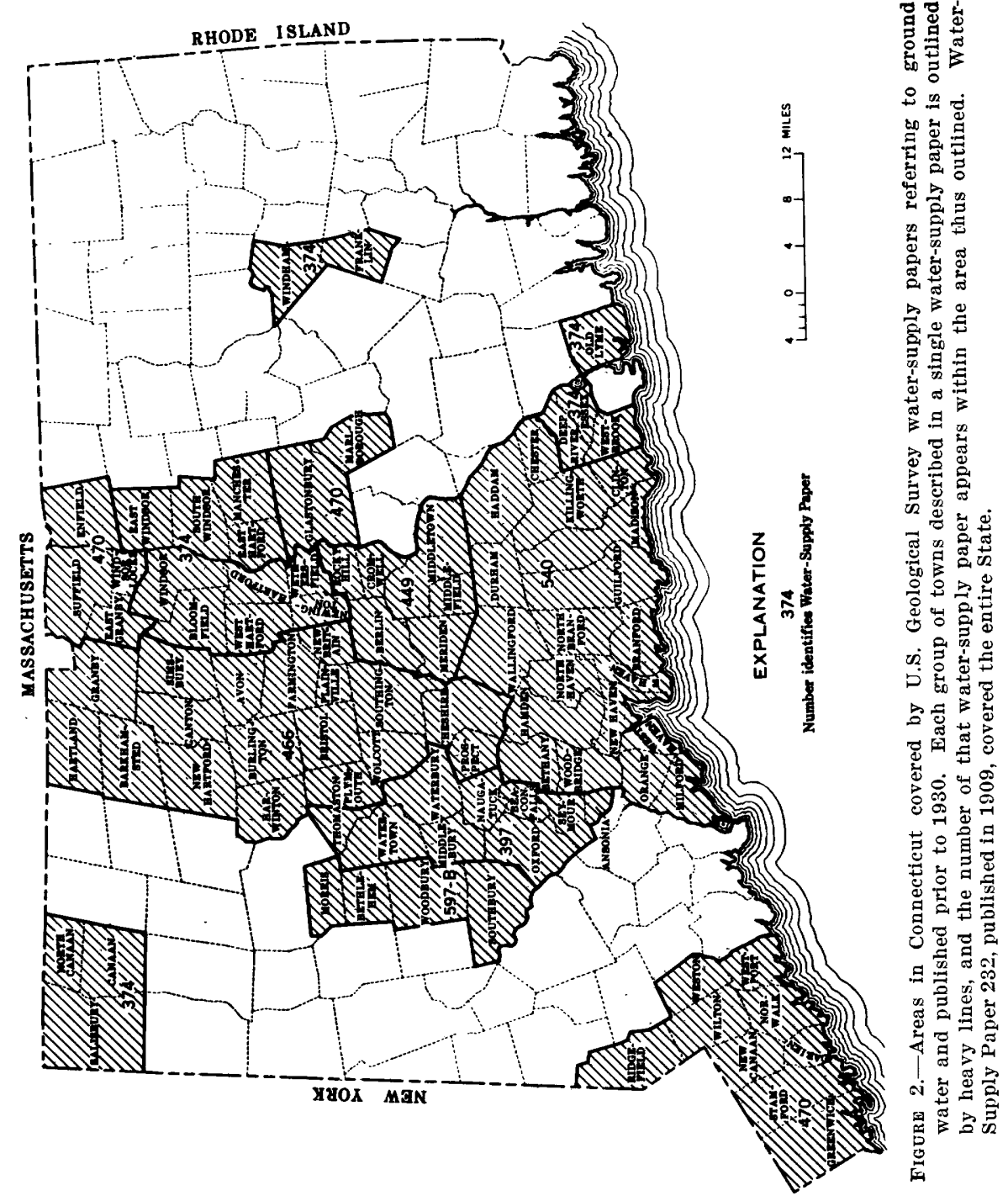


tion of the U.S. Geological Survey. Some of the data collected were published (Connecticut Ground Water Survey, 1938), and some were included in Connecticut Ground Water Survey Bulletin GW-7, of which only a few typewritten copies were prepared. In addition, about 150 well records from the towns in the Farmington-Granby area were collected but were not published.

All the publications referred to above are out of print, but copies may be examined in some libraries; in the Connecticut office of the Ground Water Branch, U.S. Geological Survey; and in the office of the Connecticut Water Resources Commission. Copies of the unpublished data mentioned above are on file in the Connecticut office of the Ground Water Branch, U.S. Geological Survey.

\section{METHODS OF INVESTIGATION}

During this investigation the surficial geology of the FarmingtonGranby area was studied and described, and a geologic map was prepared using 71/2-minute topographic quadrangle maps as a base. The contact between till and stratified drift was delineated in considerably more detail than in older maps by Palmer $(1920,1921)$ and Flint $(1930,1934)$, and some subdivision of both till and stratified drift was made. Records of more than 700 water wells, test holes, and springs were obtained from drillers and owners. A particular effort was made to obtain records of wells located where the depth to bedrock is relatively great, as an aid in preparation of the bedrock topography map (pl. 1). Detailed logs of 117 wells, including 9 wells from which some drill cuttings were examined, provided information on subsurface lithology. Water-level fluctuations were measured in 12 observation wells, mostly during the summers of 1953 and 1954, and from October 1955 through December 1958. Pumping tests were made in 2 wells. Water samples were collected from 16 wells for chemical analysis, and other analyses were gathered from various sources to provide additional information on water quality.

\section{ACKNOWLEDGMENTS}

The writer thanks all who contributed information or who aided in the collection of data for this report. Several organizations and individuals supplied valuable information from their files, among them the Bureau of Sanitary Engineering of the Connecticut State Department of Health; the Newlands Sanitary Laboratory; the Soils Section of the Connecticut State Highway Department; several water companies, water-supply associations, and municipal water departments within the report area; and water-well contractors, including Capitol Well Drilling Co., R. E. Chapman Co., The Stephen B. Church Co., Connecticut Valley Artesian Well Co., Inc., E. D. Hammond, 
Inc., Harold A. Hutteman, Layne-New York Co., Inc., Charles Pratt, Joseph J. Stack, State-Line Well Drilling, and Valley Artesian Well Co., Inc.

\section{WELL-NUMBERING SYSTEM}

In the preparation of this and other reports on ground-water resources in Connecticut, every well or test boring that was inventoried was assigned an identifying number. A separate sequence of numbers is used for each town, and prefix letters derived from the town names are added to distinguish records from different towns. Prefixes used for the towns in the Farmington-Granby area are as follows: Avon, A ; East Granby, EG; Farmington, F ; Granby, Gr; Simsbury, Si ; Suffield, Su. The prefixes are omitted from the numbers on the maps accompanying this report, but for reference the town names and boundaries appear on the maps. Springs in each town are numbered in a separate sequence, the numbers being followed by "sp."

The location of most of the wells, test borings, and springs for which reasonably complete records were collected during this investigation is shown on plate 1. 'These records are compiled as a U.S. Geological Survey open-file report, available from the Middletown, Conn., office of the Geological Survey or the Connecticut Water Resources Commission in Hartford, Conn. Logs of selected wells are included in tables 15 and 16 of this report. Wells having serial numbers greater than 200 were collected too late to be used in compiling statistical sections of the text, but they were used in preparing the bedrock-topography map.

\section{MAP-LOCATION SYSTEM}

The map-location system used in this report was adopted in 1954 by the Geological Survey, Ground Water Branch, to provide a uniform system for locating wells throughout New England. Each $7: 12^{-}$ minute quadrangle is identified by a letter and a number taken from a grid system in which letters run west to east and numbers south to north, starting with the Glenville quadrangle in extreme south western Connecticut. The names and designations of the quadrangles covering the Farmington-Granby area are as follows:

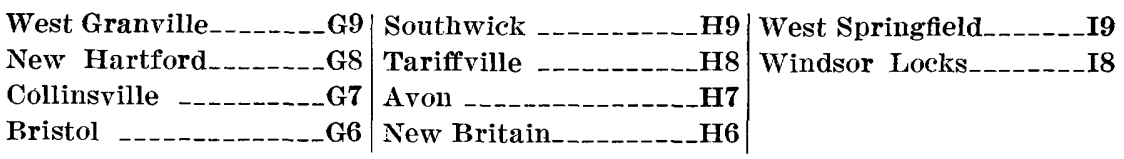

Each $71 / 2$-minute quadrangle is divided into nine $21 / 2$-minute rectangles, which are assigned numbers beginning with 1 in the upper left and ending with 9 .in the lower right, following the sequence shown in figure 3. Each of these $21 / 2$-minute rectangles is divided into nine 50 -second rectangles, which are assigned letters beginning with "a" 


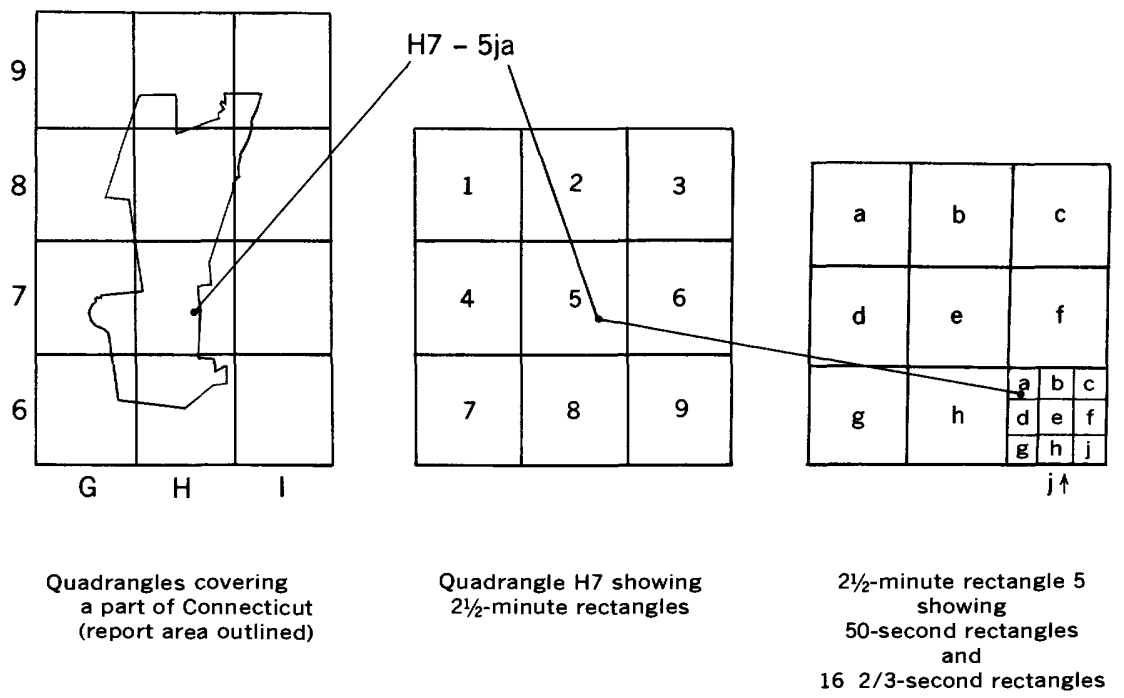

Frgure 3.-Map-location system.

in the upper left and ending with " $\mathrm{j}$ " in the lower right, omitting the letter " $i$ " for clarity. Finally, each of the 50-second rectangles is divided further into nine $162 / 3$-second rectangles, which are assigned letters following the same sequence. To indicate the location of a well by this system, the letter and number of the quadrangle in which it is located is listed first, followed in order by the number of the $21 / 2$-minute rectangle, the letter of the 50-second rectangle, and the letter of the $162 / 3$-second rectangle. Thus, the location of a well in the extreme southwest corner of the Tariffville quadrangle would be H8-7gg. This system is illustrated in figure 3 for well $\mathbf{A ~ 5 8 , ~ w h o s e ~ l o c a t i o n ~ i s ~}$ H7-5ja.

On plate 1 the letter-and-number grid for the quadrangles is shown in the margin, and grid lines outline the quadrangles and the $21 / 2^{-}$ minute rectangles. The smaller subdivisions are not outlined on the map, but the reader can estimate their positions accurately enough to find any desired well.

\section{GEOGRAPHY}

\section{PHYSIOGRAPHY AND DRAINAGE}

The Farmington-Granby area includes parts of two of the primary physiographic divisions of Connecticut, the Western Highland and the Central Lowland (Rice and Gregory, 1906, p. 2). (See fig. 4.) Fenneman (1938) considers the Western Highland of Connecticut as part of the New England Upland, and includes the Central Lowland within the Connecticut Valley Lowland. 


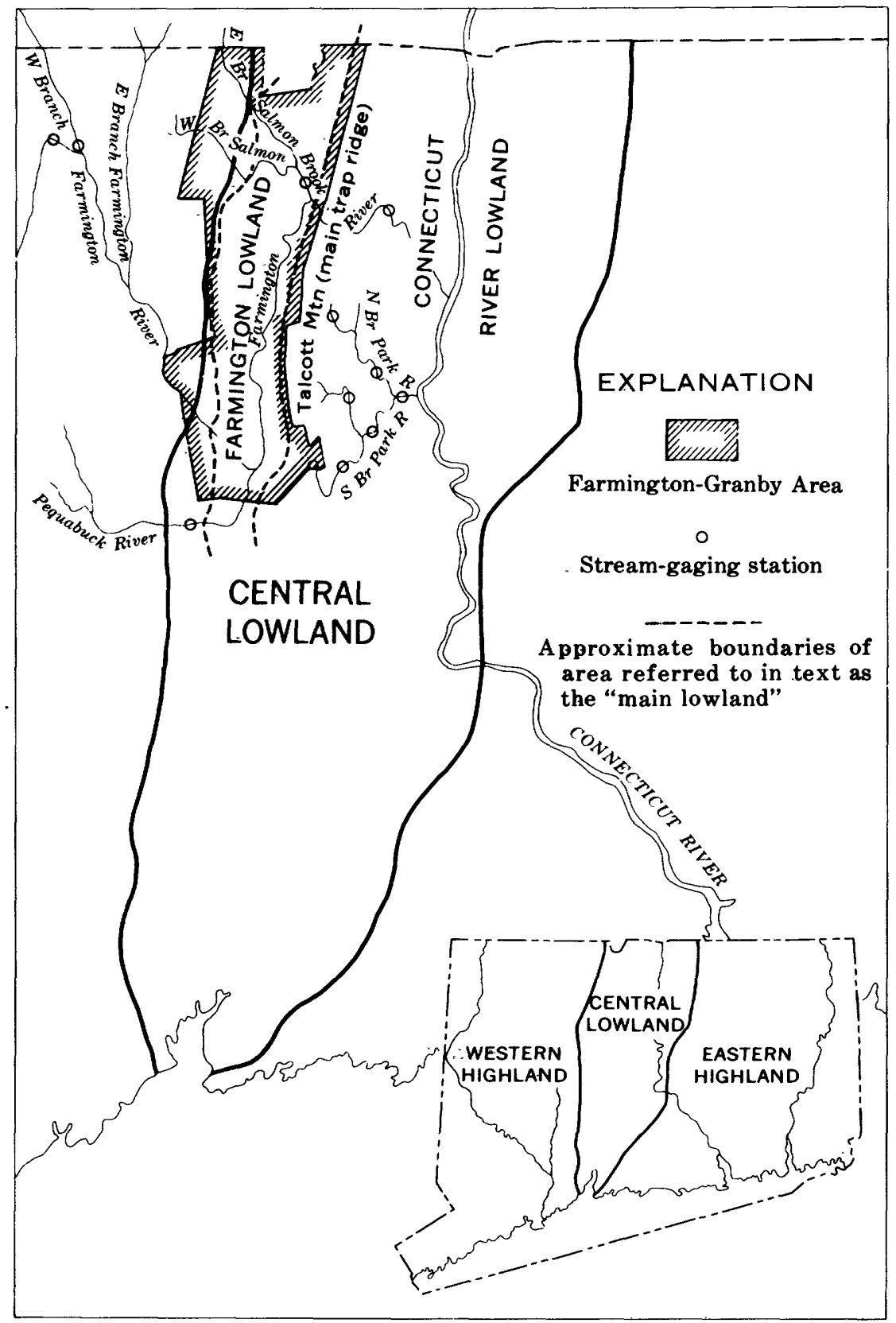

FqGure 4.-Physiographic divisions and drainage in and near the-Farmington-Granby area. 
The Western Highland is underlain by crystalline rocks, which are relatively resistant to erosion. Within the report area the land surface has moderate relief and is maturely dissected. Major streams are deeply incised in narrow valleys, and the intervening areas include many large hills that are irregular in shape but tend to be alined roughly north-south, parallel to the rock structure.

The Central Lowland is underlain by rocks of the Newark group of Triassic age, which consist chiefly of easily eroded sedimentary strata but include interbedded sheets of resistant basalt (trap rock). North of the town of Farmington, the eastern border of the Farmington-Granby area lies near the crest of a ridge formed by the principal basalt sheet in the Newark group. Between this ridge and the Western Highland, the sedimentary rocks that underlie this basalt were eroded to form the Farmington lowland. The map of the bedrock surface in the Farmington lowland (pl. 1) reveals a deep trench along the east side at the foot of the trap ridge, a line of low rounded hills down the center, and a series of small valleys along the west side. Part of the town of Farmington extends east of the main trap ridge into the Connecticut River lowland.

Pleistocene glaciation, which affected the entire FarmingtonGranby area, caused many minor modifications in the topography. In the upland, where the mantle of glacial drift is thin, the principal topographic changes involved smoothing of landforms and partial filling of valleys. In the lowland, however, thick sequences of drift were deposited, and the land surface is made up largely of terraces, many of them extensive, at altitudes ranging from 200 to 400 feet. Drumlins are found in a few places. The broad Farmington River flood plain is a postglacial feature; its very gentle northward gradient between Unionville and Tariffville is due largely to upwarping in postglacial time.

Most of the Farmington-Granby area is drained by the Farmington River. The Farmington River rises in the Western Highland of Connecticut and Massachusetts (fig. 4) and flows southeastward; it forms the west boundary of the town of Avon, and enters the Farmington lowland near Unionville. At Farmington center it turns abruptly and flows north to Tariffville, where it resumes a southeastward course and leaves the report area through a gap in the main trap ridge. The largest tributaries joining it within the area are the Pequabuck River and Salmon Brook. The part of Farmington east of the main trap ridge is drained by tributaries of the Park River, which joins the Connecticut River at Hart ford.

Stream-gaging stations are maintained on the Farmington, Pequabuck, and Park Rivers and on Salmon Brook by the Surface Water 
Branch of the Geological Survey, in cooperation with the Connecticut Water Resources Commission and other agencies. Records of daily discharge at these stations are published by the Geological Survey in a series of annual water-supply papers entitled "Surface Water Supply of the United States, Part 1-A, North Atlantic Slope Basins Maine to Connecticut."

\section{CLIMATE}

The climate of the Farmington-Granby area is humid temperate. According to the U.S. Weather Bureau, throughout the year masses of cold dry continental-polar air from Canada alternate over the area with masses of warm moist maritime air from the Gulf of Mexico, Carribean Sea, or Atlantic Ocean.

The normal annual precipitation at each of 4 Weather Bureau stations, 2 just west and 2 just east of the Farmington-Granby area, is given in table 1 . The average of these values is about 44 inches, which may be taken as the normal annual precipitation for the area. About one-quarter of this precipitation occurs as snow. The ground is usually frozen during the months of January and February, the average depth of frost penetration being less than 2 feet. Generally, the precipitation is distributed rather evenly throughout the year. (See table 1.) However, droughts or unusual storms in the area sometimes cause strong deviations from the normal monthly precipitation. Exceptionally heavy rainfall has resulted from the passage of tropical hurricanes across or near Connecticut on infrequent occasions during late summer and early fall, such as in September 1938 and August 1955. The maximum and the minimum precipitation recorded for each month at the Weather Bureau Station at Hartford, Conn., are listed in table 2. Total annual precipitation also varies considerably : the highest yearly total recorded at Hartford was 62.94 inches, in 1955; the lowest was 32.26 inches, in 1957.

\section{TABLE 1.-Normal monthly precipitation}

[Data from U.S. Weather Bureau records. Normal values are means based on the period 1921-50. Records not covering this entire period were adjusted by the U.S. Weather Bureau. The actual number of years of record listed for these four stations in the 1956 Annual Summary of Climatological Data, New England (U.S. Dept. Commerce, 1957) is as follows: Barkhamsted, 25; Collinsville, 26; Hartford Weather Bureau, 8; Hartford Brainard Field, 95]

\begin{tabular}{|c|c|c|c|c|c|c|c|c|c|c|c|c|c|}
\hline Station & Jan. & Feb. & Mar. & Apr. & May & June & July & Aug. & Sept. & Oet. & Nov. & Dec. & Year \\
\hline $\begin{array}{l}\text { Barkhamsted...... } \\
\text { Collinsville }\end{array}$ & $\begin{array}{l}3.48 \\
4.35\end{array}$ & 2. 99 & $\begin{array}{l}3.59 \\
4.38\end{array}$ & $\begin{array}{l}3.55 \\
4.40\end{array}$ & $\begin{array}{l}\text { 3. } 76 \\
3.84\end{array}$ & 4. 22 & 4. 22 & $\begin{array}{l}3.37 \\
4.39\end{array}$ & $\begin{array}{l}4.85 \\
4.80\end{array}$ & 3. 24 & 3. 80 & 3.27 & 44. 34 \\
\hline $\begin{array}{l}\text { Hartford, Weather } \\
\text { Bureau, Bradley }\end{array}$ & & & & & & & & & & & & & \\
\hline Field & 3.15 & 2. 66 & 3.81 & 3. 56 & 3.66 & 3. 62 & 3.56 & 3. 54 & 3.44 & 2. 80 & 3. 48 & 3. 29 & 40.57 \\
\hline Field & 3.74 & 3.13 & 3.53 & 3.55 & 3.77 & 3.76 & 3.93 & 3.67 & 3.41 & 2. 70 & 3. 85 & 3.49 & 42.53 \\
\hline Averag & 3. 68 & 2.93 & 3.83 & 3. 76 & 3. 76 & 3.93 & 3.90 & 3. 74 & 4. 12 & 3. 01 & 3.67 & 3.35 & 43. 68 \\
\hline
\end{tabular}

$696-293 \quad 0-64-2$ 
GEOLOGY AND GROUND WATER, FARMINGTON-GRANBY, CONN.

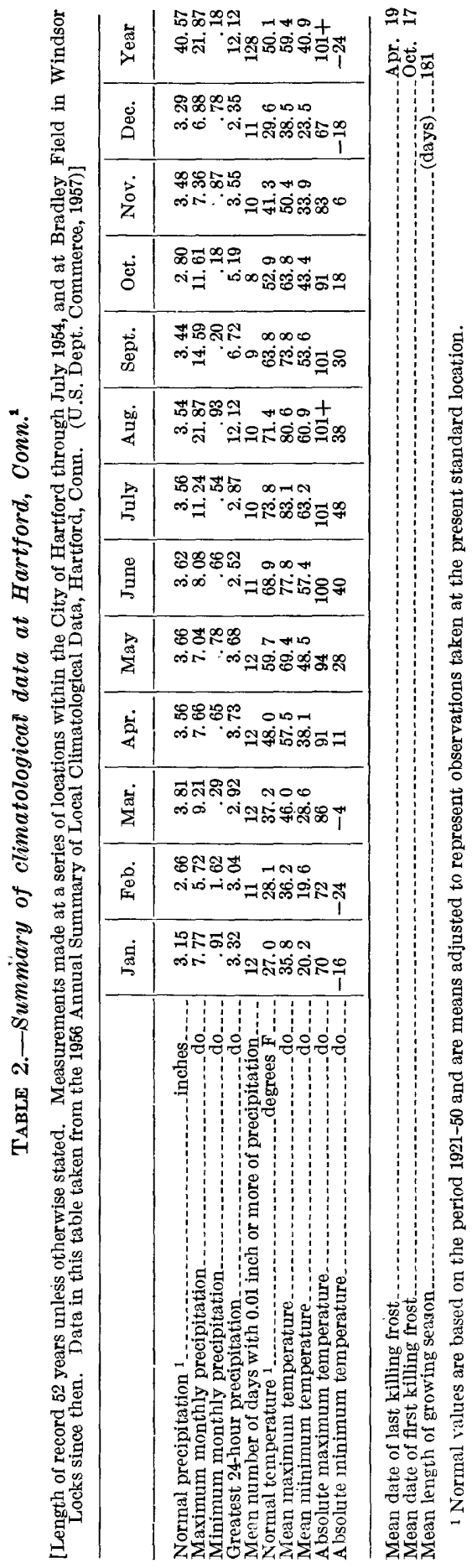


Other climatological data for the Weather Bureau Station at Hartford, Conn., are summarized in table 2. Measurements of the evaporation rate during the summer months, taken by the Water Bureau of the Hartford Metropolitan District Commission at a reservoir in West Hartford near the Farmington town line, are summarized in table 3.

TABIE 3.-Evaporation at Reservoir No. 1, West Hartford, Conn.

IData from the Hartford Metropolitan District Commission, based on daily measurements of evaporation from a standard Weather Bureau type Class A pan filled daily to a level 4 inches from the bottom and located on the surface of Metropolitan District Reservoir No. 1, in West Hartford]

\begin{tabular}{l|r|r|r}
\hline Month & $\begin{array}{c}\text { Mean } \\
\text { evaporation } \\
\text { (inches) }\end{array}$ & $\begin{array}{c}\text { Number of } \\
\text { years of record } \\
\text { (through 1956) }\end{array}$ \\
\hline May & 4.65 & 34 \\
June & 5.61 & 37 \\
July & 6.11 & 38 \\
September & 5.42 & 37 \\
October & 4.10 & 35 \\
& & 2.95 & 28 \\
\hline
\end{tabular}

\section{POPULATION}

The broad flood plains and terraces of the Farmington lowland attracted early settlers by reason of their easily tillable and relatively fertile soils, and parts of the several towns in the Farmington-Granby area were settled during the middle and late 17th century. These towns have grown considerably since then, particularly since 1900 . Recent population figures are listed in table 4.

TABLE 4.-Area and population of towns in the Farmington-Granby area

\begin{tabular}{|c|c|c|c|}
\hline & $\begin{array}{c}\text { Area } \\
\text { (square miles) }\end{array}$ & $\begin{array}{l}\text { Population, } \\
\text { from } \\
1950 \text { census }\end{array}$ & $\begin{array}{l}\text { Estimated } \\
\text { population, 1957 } \\
\text { (Connecticut } \\
\text { Dept. Health, } \\
\text { 1957, except } \\
\text { as noted) }\end{array}$ \\
\hline $\begin{array}{l}\text { Avon } \\
\text { East Granby (entire town) } \\
\text { Part within report area } \\
\text { Farmington } \\
\text { Granby } \\
\text { Simsbury } \\
\text { Suffield (entire town) } \\
\quad \text { Part within report area }\end{array}$ & $\begin{array}{l}22.6 \\
(17.8) \\
18.0 \\
38.2 \\
40.9 \\
24.5 \\
(43.1) \\
17.4\end{array}$ & $\begin{array}{c}3,171 \\
(1,327) \\
2610 \\
7,026 \\
2,693 \\
4,822 \\
(4,895) \\
-\end{array}$ & $\begin{array}{c}4,300 \\
(1,600) \\
2734 \\
8,800 \\
3,600 \\
6,500 \\
(5,900) \\
31,650\end{array}$ \\
\hline Total for report area & 141. 6 & $\mid \ldots \ldots \ldots$ & 33,084 \\
\hline
\end{tabular}

1 Area measured with planimeter on topographic maps.

2 Estimated from data supplied by the Board of Assessors on the number of dwelling houses in the report area and the number in the entire town.

3 Estimated by town clerk. 


\section{GEOLOGY}

\section{GEOLOGIC UNITS}

The bedrock of the Farmington-Granby area includes the Collinsville gneiss of Rodgers and others (1956) and the Hartland formation, both of which consist of crystalline rocks of pre-Triassic age, and the Newark group, which consists of sedimentary and igneous rocks of Triassic age. Overlying the bedrock in most places is a mantle of Pleistocene glacial till, which forms ground-moraine and drumlin deposits. The till and bedrock are overlain in places by bodies of stratified glacial drift, which include ice-contact deposits and valley-train deposits. Locally, the glacial deposits are overlain by alluvium of Recent age.

The surface distribution of the geologic units is shown on the geologic map (pl. 1), and subsurface relations are illustrated by crosssections (pl.2). The lithology and water-yielding properties of these units, which are discussed in later sections of this report, are summarized briefly in table 5 .

\section{GEOLOGIC HISTORY}

\section{PREgLaCial history}

The oldest exposed rocks in the Farmington-Granby area were deposited as a sequence of muds and sands in early Paleozoic time. During the mountain-building activity that followed, these sediments were folded and metamorphosed to the mica quartzite and mica schist of the Hartland formation. Into this formation were intruded igneous masses which were gradually metamorphosed into the Collinsville gneiss of Rodgers and others (1956) and the gneiss bodies in Granby.

By Triassic time erosion had reduced the Paleozoic topography of central Connecticut to a surface of relatively low relief (Barrell, 1915). During Late Triassic time the sediments of the Newark group were laid down on this surface, in a basin formed principally by movement along the great fault that forms the east-margin of the Central Lowland (fig. 4). Studies by Barrell (1915), Krynine (1950) and others indicate that these sediments were deposited in alluvial fans, flood plains, lakes, and swamps by streams rising in the Eastern Highland. Recurring downward movement of the basin along the fault made possible a great accumulation of sediments. At times, igneous material was injected into the body of sediment as dikes or sills or extruded at the land surface as lava flows.

Sedimentation ceased by the close of Triassic time, and probably during Jurassic time (Barrell, 1915) the newly deposited strata of the Newark group were broken into blocks and tilted by numerous faults. 


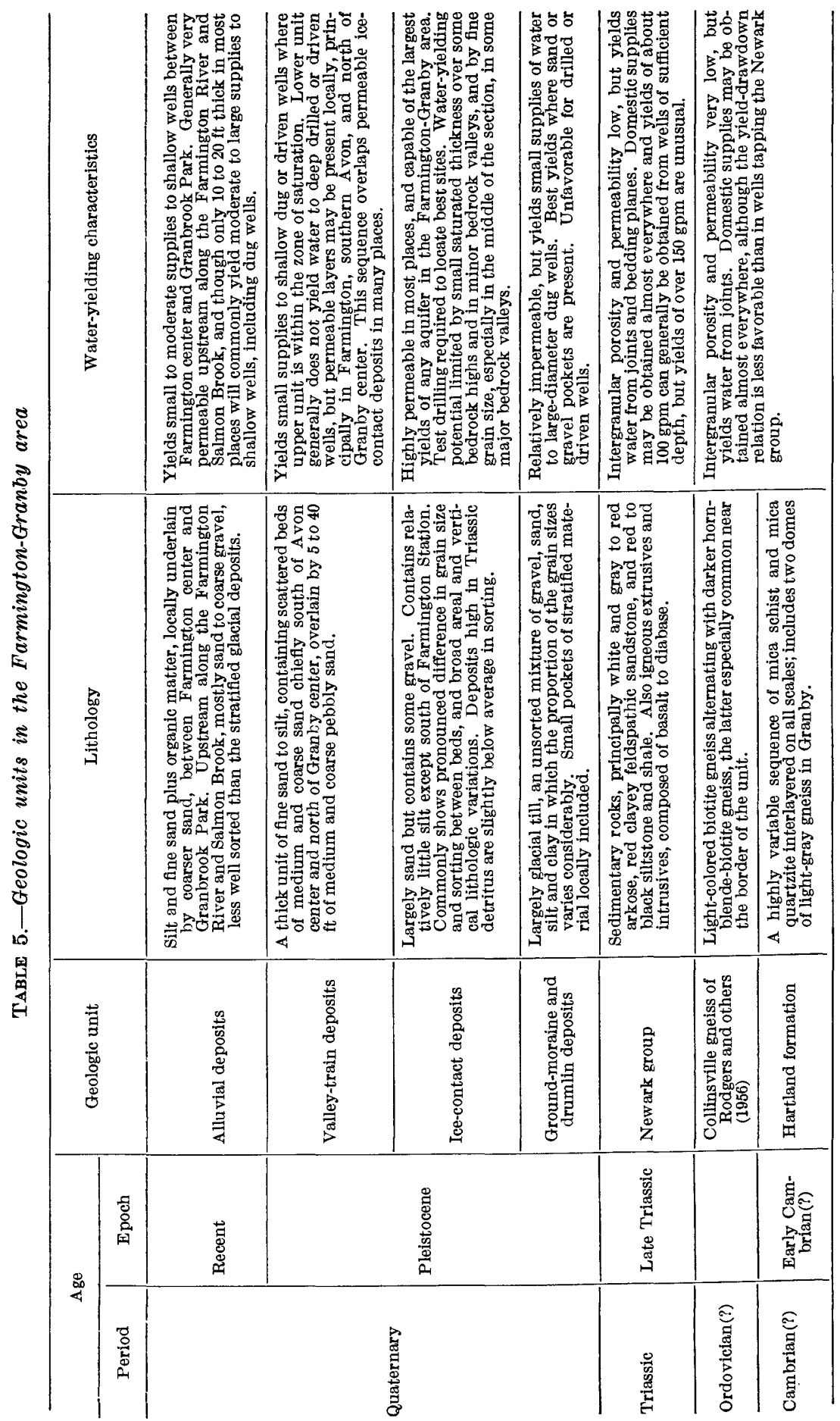


Most of the joints in both crystalline and Triassic rocks of the Farmington-Granby area may have developed during this period of faulting. Some warping of the strata occurred also.

The development of the present:bedrock topography of the Farmington-Granby area began with the uplift in early Tertiary time of a surface of low relief that is now preserved as the maximum level of local mountain summits. Most of the major streams were then flowing southeastward. In areas of crystalline rock, streams were able only to entrench themselves following the.uplift; however; more rapid erosion was possible in the relatively soft Newark sediments, and a new trunk stream eventually developed that entered the FarmingtonGranby area south of Congamond Lakes and flowed southward just west of Manitook and Talcott Mountains. Tributary streams cut valleys parallel to the trunk stream along the western side of the developing Farmington lowland.

\section{GLACIATION}

During the Pleistocene epoch, continental glaciation greatly modified the landscape of the Farmington-Granby area. In places, the main bedrock valley was cut to depths of more than 100 teet below sea level by the glacial ice. As the glaciers overrode the area they removed most of the weathered mantle rock, some fresh bedrock, and any outwash which may have been laid down ahead of the advancing ice. Much of the detritus picked up by the ice was smeared on to the underlying bedrock, particularly in valleys transverse to ice movement, and additional detritus was dropped onto the land surface as the ice melted. The unsorted glacial debris (till) thus deposited formed the ground moraine and drumlins of the area.

The glacial drift in southern New England is generally considered to be the product of the latest or Wisconsin stage of Pleistocene glaciation. Flint (1953) tentatively suggests that ice advanced south of the Farmington-Granby area twice during Wisconsin time; scant evidence for a glacial readvance was observed by the writer, however. Thin layers of till were observed resting on or within deposits of stratified drift in a few exposures, and in one exposure two layers of till were present; but these few atypical occurrences of till (p. 48) can be considered as unsorted superglacial material that slumped off the ice during melting or, in a few places, possibly as the products of local.ice movement.

Subsurface information also suggests that all the glacial deposits are products of a single ice advance. Logs of several wells in southern Farmington indicate that below the thick sequence of stratified drift that fills the main bedrock valley, a single till sheet is present immediately above the bedrock or separated from it by a thin layer 
of sand, presumably laid down in front of the advancing ice. (See logs of wells F 79,105, 116, 118, and 120, in table 15.) No other till layer was reported by drillers or indicated in samples in any of these wells, although the driller of well $\mathrm{F} 118$ reported penetrating sand with several layers of gray, gravelly, moderately soft "hardpan" from 100 to 180 feet in depth. The term "hardpan" is usually applied to till, but the description of this "hardpan" suggests a stratified deposit. Elsewhere in the deep Farmington bedrock valley, where the thickest sequences of glacial drift occur, well logs indicate no major changes in lithology at depth that cannot be interpreted to be a result of overlap of older by younger members of the latest glacial sequence. (See, for example, wells Si 51, EG 38, A 24, A 73, in tables 15 and 16.) Samples from a well at the Trumbull Electric Co. in Plainville record a sequence of sand and clay layers (containing no till) down to an altitude of -25 feet.

\section{DEGLACTATION}

As a result of changes in climatic conditions, the rate of melting of the ice eventually began to exceed the rate of accumulation, and the ice sheet began to shrink northward. Because the ice sheet melted downward from the top as well as inward from the edge, the terminal zone often became too thin to maintain flow and therefore "stagnated." Melt-water streams, flowing within and away from the decaying ice, moved rock debris from the ice and deposited it as stratified drift. Much of this stratified drift was laid down against and over masses of stagnant ice as much as several miles away from the front of the still-active ice, and the irregular depressions in the present surface of the drift reflect the former position of th ese buried ice masses. Another result of downward melting was that hilltops were exposed before valleys, hence the deposition of stratified materials proceeded from high to low altitudes, as well as from south to north. Early in deglaciation, relatively coarse materials were laid down in tunnels beneath the ice or spread out on the ice surface and let down as melting took place. They are now present at the bas e of the stratified drift in some localities. As the ice melted further, lakes and valleys developed which filled with sediments that were generally fine at first but became coarser as accumulation continued.

The oldest stratified deposits in the Farmington-Granby area are ice-contact deposits at altitudes of 570 to 300 feet in t'ie western upland of Avon and Farmington, and at altitudes of $\varepsilon 00$ to 310 feet along the Roaring Brook and Lake Garda valleys. Later, as the ice melted back from the west side of the main lowland south of River Glen, sediments filled the intervening space. The oldest of these deposits were derived from the local Triassic sedimentary rocks and 
are red. The upward gradation to gray sediment marks the time when the Farmington River, with its load of crystalline rock debris, was able to abandon its earlier outlet through the Lake Garda valley and enter the west side of the main lowland. The surface of these deposits of crystalline-rock origin slopes southeastward from 270 feet altitude in Unionville to 220 feet just north of U.S. Highway 6.

Later, melting of the ice between River Glen and Farmington center permitted drainage from the Farmington River and from the melting ice in the main lowland to abandon its course south ward down the west side of the ice mass in favor of lower paths via the middle and east parts of the lowland. Glacial drift present in the lowland in Southington (about 5 miles south of the report area) at least partly blocked the southward flow of melt-water drainage through this area, forming a lake whose level would have reached at least 165 feet (present altitude) at Farmington center. Thin reddish clay-silt layers, containing one mass of pebbles and cobbles that presumably was dropped from floating ice, are exposed at an altitude of about 180 feet in Round Hill (fig. 10), and many elay-silt layers were penetrated by the Trumbull Electric well in Plainville (p. 61). These materials indicate that some ponding did oceur. The valley-train deposits in Farmington, however, contain much fine to coarse sand, which implies that most deposition took place in active currents. Finally, a uniform stream gradient was established between Unionville and the Quinnipiac water gap at South Meriden (about 12 miles south of the report area), and a continuous coarse fluvial sand.mantle was laid down. This sand layer is believed to overlap the older ice-contact deposits along a line near Hyde Road in Farmington. Its upper surface reaches 200 to 210 feet in altitude and is correlated with erosional terraces found at about 220 feet in Unionville.

The altitude of the ice-contact deposits increases northward from Farmington, although there are local breaks in the northward rise, which presumably reflect shifts of drainage to lower courses. For example, Salmon Brook drained southward for some time through gaps in the Barndoor Hills, forming terraces at altitudes of about 330 feet; subsequently, however, the ice in the valley around Granby center melted sufficiently to allow Salmon Brook to shift to its present course around the north end of these hills and form terraces that reach only 250 feet in altitude. The seattered delta deposits exposed along the bluff west of the present Farmington River between the Farmington-Avon line and Tariffville suggests that a lake or lakes were present along this valley during construction of these deposits.

From the above diseussion it may be noted that most of the stratified drift in the Farmington-Granby area was laid down by waters draining southward to the Quinnipiac water gap at South Meriden. 
However, when melting of the ice permitted meltwater to flow out through an existing water gap at Tariffville into the Connecticut River lowland, the Farmington and Pequabuck Rivers abandoned their southward course to flow to this new, lower outlet. The upper part of the valley-train deposits north of the Avon-Farmington line were formed by these streams and were graded to the Tariff ville gap. Some of the ice-contact deposits north of the Barndoor Hills also were graded to this gap.

The streams later began to entrench themselves below the original surface of the valley-train deposits, probably owing to lowering of base level in the Connecticut River lowland (Lougee, 1938, p. 59) and stream terraces were cut in many places along the Farmington River.

\section{POSTGLACIAL history}

The postglacial history of the Farmington-Granby area consisted mainly or erosion by the various streams and redeposition of thin mantles of alluvium on their flood plains. Swamp deposits accumulated in many of the undrained ice-block depressions left throughout the areas of ice-contact deposits, and in poorly drained till areas. Rebound of the earth's crust tilted all surfaces slightly southward and decreased the northward gradient of the Farmington River.

\section{PHYSICAL CHARACTERISTICS AND WATER-YIELDING PROPERTIES OF THE GEOLOGIC UNITS}

\section{CONSOLIDATED ROCKS}

\section{CRYSTALIINE ROCKS OF PRE-TRIASSIC AGE}

[Collinsville gneiss of Rodgers and others (1956) and Hartland formation]

The term "crystalline rocks" has been used in many publications dealing with the geology of Connecticut to refer to the metasedimentary and metaigneous rocks that underlie the eastern and western highlands of the State; for example, Rice and Gregory (1906), Palmer (1921), and Rodgers and others (1956). These rocks have been divided into a number of formations, two of which (the Collinsville gneiss and the Hartland formation) occur within the Farmington-Granby area. The Collinsville gneiss, which is especially well exposed at the village of Collinsville in the town of Canton, was originally named the Collinsille granite gneiss by Gregory (Rice and Gregory, 1906, p. 105-7); the term "granite" was subsequently dropped from the Preliminary Geological Map of Connecticut (Rodgers and others, 1956). The Hartland formation was first described by Gregory as the Hartland schist (Rice and Gregory, 1906, p. 96-100) and correlated with the Hoosac schist (Emerson, 1892) of Massachusetts; however, Gates $(1951,1954)$ used the term Hart- 
land formation and mentioned that this unit.is correlated with the Hoosac and Rowe formations of Massachusetts, the Rowe having been described as overlying the Hoosac (Emerson, 1892). Rodgers and others (1956) also used the term Hartland formation on their preliminary geological map of Connecticut.

These two formations are discussed separately here, where appropriate; but as their water-yielding properties are very similar, they are considered together in this report under the general heading of "crystalline rocks."

\section{AREAL DISTRIBUTION AND THICKNESS}

Crystalline rocks occur only near the western margin of the Farmington-Granby area; the boundary between them and the Newark group to the east is shown on plate 1 . No accurate estimates of the thickness of these rocks are available, but they undoubtedly are of great thickness. The Collinsville gneiss of Rodgers and others (1956) is present only in western Avon, chiefly west of Roaring Brook, and in the extreme northwest corner of Farmington. The Hartland formation is the bedrock in western Granby and northwest Simsbury, and also in a tiny part of northwestern Farmington.

\section{LITHOLOGY}

The "Preliminary Geological Map of Connecticut" (Rodgers and others, 1956) gives the following description of the Collinsville gneiss :

Light-colored gneiss composed of feldspar (oligoclase and/or K-feldspar), quartz, and biotite, with minor hornblende, garnet, chlorite, and muscovite, alternating with darker gneiss partly high in biotite alone but more commonly dominantly hornblende, with biotite and plagioclase, and minor quartz, 'garnet, epidote, chlorite, and perhaps augite. Hornblendic rocks especially common near border. Gneiss cut by dikes of pegmatite and fine-grained granite.

The Hartland formation consists of a highly variable sequence of mica quartzite and-mica schist interlayered on all scales. The ratios of the minerals muscovite, biotite, and quartz range widely; feldspar is widespread but generally quite subordinate. Kyanite, staurolite, and especially garnet schists are relatively.common but local in extent. Pegmatite sills and dikes are abundant locally.

Intruded in the Hartland formation are two masses of light-gray gneiss in western Granby, referred to on the "Preliminary Geological Map of Connecticut" as "gneiss domes." The southern dome underlies a circular area about 1 mile in diameter centered just south of the intersection of Barkhamsted Road and Case Street, Granby; the northern dome, in extreme -northwest Granby, includes all the area north of Belden Brook plus a small section to the south. The gneiss probably consists mostly of feldspar, quartz, and biotite, but hornblende gneiss is reported in the northern area. 
The southern gneiss dome forms high ground; the northern gneiss dome, however, is apparently much less resistant to erosion than the schist around it, and forms a marked topographic basin bounded on at least three sides by higher areas underlain by schist. The Collinsville gneiss of Rodgers and others (1956) forms hills, but they are lower than nearby hills of schist.

Gneiss bedrock so deeply weathered that it can be easily dug with a shovel was observed at several places within the area of the northern gneiss dome. In some exposures the weathered gneiss is overlain by fresh glacial till, which establishes that the weathering occurred before the last glaciation. Exposures of this sort, which are relatively rare in glaciated New England, are present on both sides of State Route 189 about 1 mile north of the Silver Street intersection, and west of Silver Street along the north bank of the stream, 0.25 mile south of well Gr 98. Preglacially weathered bedrock may also be preserved locally within the area of the Collinsville gneiss of Rodgers and others (1956), as indicated by the $\log$ of well A 109, which is reported to penetrate 103 feet of "decayed rock" (table 15).

\section{STRATIGRAPHIC RELATIONS}

The Triassic strata overlie crystalline rocks, although a fault forms the line of contact at the surface in many places. Wheeler (1937) mentions evidence demonstrating these relations from localities along the western border of the Triassic lowland in Connecticut and Massachusetts. Within the Farmington-Granby area, well A 90 (table 16) is reported to pass through Newark beds into crystalline rocks.

Relations between schist and gneiss bodies within the crystalline rocks are not as clear but appear to be fairly consistent within the Farmington-Granby area. Gregory (Rice and Gregory, 1906, p. 107) reports that the contact between the Collinsville gneiss and the Hartland formation has not been observed, but that

exposures in the Farmington River at Unionville show schist wrapping closely around gneissoid granite, *** and in general the schist is seen to have adjusted itself to the granite and to dip away from it; also, the axes of the larger folds [in the gneiss] dip under the schist.

Similar structural relations apparently prevail in Granby, as the "Preliminary Geological Map of Connecticut" refers to the gneiss bodies as domes, and Wheeler $(1937$, p. 36 ) considers the northerly gneiss area to be an anticlinal basin. Both Wheeler and Gregory state that gneiss bodies probably intruded the Hartland formation, and were later metamorphosed. 
The relations discussed above indicate that the crystalline rocks are pre-Triassic in age, and suggest that the schist is at least slightly older than the gneiss. Prindle and Knopf (1932, p. 291-3) consider the Hoosac schist of Massachusetts, to which the Hartland formation is apparently equivalent in part, as Lower Cambrian(?). The Collinsville gneiss is considered by Gregory to be Ordovician(?) in age. Radioactive age determinations of 350 to 360 million years for pegmatites associated with rocks intrusive in the Hartland formation near Branchville in southeastern Connecticut are mentioned by Rodgers (1952) as suggesting a Late Ordovician date for these intrusions, in agreement with the earlier studies.

\section{WATER-YIELDING PROPERTIES}

The amount of intergranular pore space in crystalline rocks is quite small; two authors quoted by Meinzer (1923, p. 10) report average (mean) porosity of 0.16 percent and 1.2 percent for granite, schist, and gneiss. With such low porosity, the intergranular pore spaces are small and poorly connected, permitting little and execedingly slow transmission of water. Accordingly, where secondary openings such as joints or fractures are present they contain most of the water found in these rocks. (See fig. 5.) Such water-bearing openings yield the bulk of the water drawn from wells drilled in the crystalline rocks.

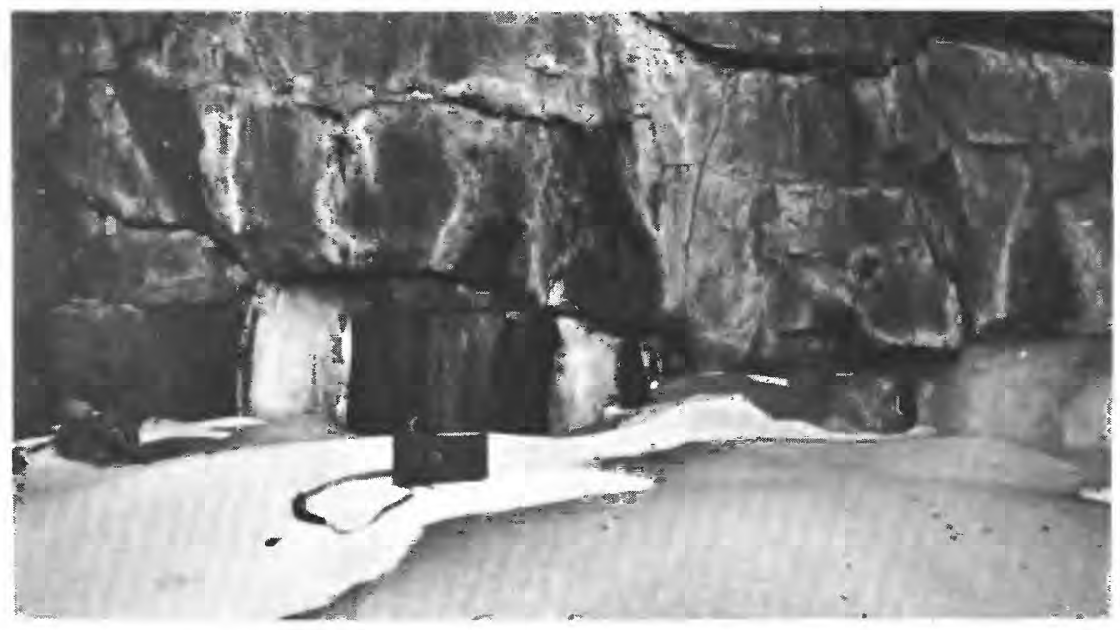

Figure 5.-Outcrop of crystalline rock, showing ice formed when ground water issued from joint openings in the rock during winter months. The ice accumulation is typical of many outcrops throughout Commecticut, and illustrates the occurrence of water in fractures in the bedrock. 
Jointing in the crystalline rocks of Connecticut was discussed thoroughly by Ellis (1909), and the following general remarks have been summarized chiefly from this work. Steeply dipping or "vertical" joints are the most common type of joints. On the basis of 75 exposures, the mean inclination of vertical joints is $74^{\circ}$, and more than half the joints have inclinations of between $80^{\circ}$ and $90^{\circ}$. At least one system of extensive parallel joints is present in most localities, plus numerous shorter cross-joints connecting the systematic joints. The vertical joints in the more massive gneisses are generally more open and continuous than those in the schistose rocks, but are ordinarily less regular in arrangement and more widely spaced.

The spacing of vertical joints is characteristically irregular. In every quarry observed by Ellis in Connecticut where jointing was developed over a considerable area the joints were found to be much more closely spaced at certain points than at others, constituting a series of zones of close jointing separated by intervals in which the distances between joints were much greater. Ellis estimates that, in those areas of crystalline rocks where jointing is well developed, the average spacing is between 3 and 7 feet; but in other areas a spacing of at least 100 feet prevails. The overall average spacing between vertical joints of the same series above a depth of 50 feet probably exceeds 10 feet.

So-called horizontal joints, which are inclined at $20^{\circ}$ or less, are also present in the crystalline rocks, although they are not as common as the vertical joints. They are best developed in the more massive gneisses, where they tend to follow approximately the bedrock surface or the foliation; they are usually lacking in schists. They diminish in number rapidly with depth; Ellis estimated that they average 1 foot apart for the first 20 feet, 4 to 7 feet for the next 30 feet, and 6 to 30 feet for the next 50 feet.

Minor fractures are present parallel to the foliation of both schists and gneisses; these fractures are not as extensive nor as regular as joints and probably are of small importance below the weathered surface zone.

Ellis concludes from his observations that the size of openings along joints decreases with depth, owing to increased pressure, decreased opportunity for lateral expansion below the level of minor topographic relief, and reduced effect of weathering. This means that bedrock is more likely to yield water near the land surface than at depth.

A total of 41 wells finished wholly or partly in crystalline rock were studied during the preparation of this report. Sixteen of these are finished in the Collinsville gneiss of Rodgers and others (1956), 
13 in the gneiss domes within the Hartland formation, and 12 else- where in the Hartland formation. All but two were drilled to provide domestic or farm supplies. Well A 90 is reported to penetrate strata of the Newark group in addition to crystalline rock (well Gr 27 may also), and well A 106 is a test well that was screened in glacial till and drilled into rock; these three wells are not included in the compilations of yield and specific capacity data referred to below.

\section{DEPTH OF WELLS}

The domestic and farm wells finished in the Hartland formation range in depth from 60 to 412 feet. Wells in the gneiss domes and wells in the schist each have a median depth of 155 feet. Domestic and farm wells in the Collinsville gneiss of Rodgers and others (1956) range in depth from 58 to 420 feet and have a median depth of 101 feet. The relative water-yielding capacity of these rock types can be appraised more precisely if the casing length is subtracted from the total depth.of each well. By this means, differences in depth to solid bedrock are eliminated, and the rock thicknesses from which well yields were obtained can be compared. The median rock thickness penetrated is 50 feet for wells in the Collinsville gneiss of Rodgers and others (1956) and 61 feet for wells in the gneiss domes in Granby, whereas 114 feet is the median rock thickness penetrated for wells in the schist. Although some domestic and farm wells in crystalline rocks penetrate as much as 400 feet of bedrock, 85 percent penetrate rock thicknesses of 9 to 130 feet.

Two factors suggest that there should be a practical limit to the depth of wells finished in crystalline bedrock. As the spacing of vertical joints is known to differ typically from a few feet at some points to many feet or tens of feet at others, it follows that a well drilled at one site may not intersect water-yielding fractures in the upper part of the bedrock, even though such fractures may be present nearby. Further, as joint openings are believed to decrease in size with depth, it follows that there is less chance of obtaining an adequate yield by drilling an unsuccessful well deeper than by penetrating the upper part of the bedrock at a new site. After study of the data available to him, Ellis $(1909$, p. 94$)$ concludes that "if a well has penetrated 250 feet of [crystalline] rock without success the best policy is to abandon it and sink in another location."

Evidence from well records collected for this report tends to support Ellis' estimate of 250 feet as the maximum advisable penetration of crystalline rock. Only 4 of 41 wells tapping crystalline bedrock penetrated more than 250 feet of rock. Well A 78 was originally 100 feet deep, penetrating 62 feet of rock, and was reported to yield $3 \mathrm{gpm}$ 
at a drawdown of nearly 73 feet during a bailer test. The specific capacity was therefore $0.04 \mathrm{gpm}$ per foot. Because the supply was inadequate, the well was deepened an additional 320 feet, after which the yield was $5 \mathrm{gpm}$ at a drawdown of 390 feet, and thus the well had a specific capacity of $0.01 \mathrm{gpm}$ per $\mathrm{ft}$. As this was still inadequate, another well, A 78a, was drilled nearby to a depth of 135 feet and penetrated 95 feet of rock; this well yielded $4 \mathrm{gpm}$ at a drawdown of 117 feet and thus had a specific capacity of $0.03 \mathrm{gpm}$ per $\mathrm{ft}$. The superior results of the second attempt are obvious. Another deep well in crystalline bedrock, $\operatorname{Gr} 125$, is 412 feet deep and penetrates 404 feet of bedrock below the casing. Although this well flows a very slight amount and the entire production was obtained below 405 feet, the yield was only $11 / 2 \mathrm{gpm}$ when the water level was bailed virtually to the bottom, indicating a specific capacity of $0.004 \mathrm{gpm}$ per foot. A third well, Gr 27 , penetrates 271 feet of rock; it yields only $4 \mathrm{gpm}$. The fourth well, Si 59a, penetrates 291 feet of crystalline rock and yields $40 \mathrm{gpm}$ at a 250 -foot drawdown; no information is available, however, on how much of this yield was obtained in the lower 41 feet of rock.

\section{YIELDS OF WELLS}

The reported yields of 22 domestic and farm wells finished in the Hartland formation ranged from $11 / 2$ to $50 \mathrm{gpm}$, and the median yield was close to $9 \mathrm{gpm}$ for wells in both the gneiss domes and the schist. In the Collinsville gneiss of Rodgers and others (1956), 14 domestic and farm wells ranged in yield from 0.75 to $50 \mathrm{gpm}$, and the median yield was $5 \mathrm{gpm}$.

Reported yield is not an entirely adequate measure of well success, because in many wells it is not the maximum yield possible; in addition, the drawdown which is required to obtain the yield is not taken into account. A more significant measure is specific capacity, or gallons per minute per foot of drawdown. The specific capacity of 14 domestic and farm wells in the Hartland formation ranged from 0.004 to about $1.4 \mathrm{gpm}$ per $\mathrm{ft}$; the median was $0.13 \mathrm{gpm}$ per foot, and the wells in gneiss averaged slightly better than the wells in schist, which are somewhat deeper. The median specific capacity of 6 domestic and farm wells in the Collinsville gneiss of Rodgers and others (1956) was $0.035 \mathrm{gpm}$ per $\mathrm{ft}$, however, and the range was from 0.03 to 0.45 gpm per ft.

These data on yield and specific capacity suggest that both the gneiss domes and the schist within the Hartland formation are considerably more favorable than the Collinsville gneiss as a source of water. However, the number of wells studied is small, and additional information is needed for a more accurate analysis. 
Several authors have reasoned that gneiss should be a better source of ground water than schist. R. V. Cushman (written ${ }^{*}$ communication) points out, that gneiss is a coarser grained more brittle rock, and hence should be more fractured. Ellis $(1909$, p. 98) reports that there are more horizontal joints in granite gneiss than in schist, especially near the surface, and reasons that this would result in better interconnection of joints and more ready circulation of ground water. $\mathrm{He}$ suggests also (p. 63, 70) that the fractures in granite gneiss are larger, although perhaps less numerous than those in schist. Well records, however, do not consistently show higher yields from either rock type. The data presented by Ellis are summarized as follows:

Yields from all types of wells

\begin{tabular}{|c|c|c|c|c|}
\hline Rock type & $\begin{array}{l}\text { A verage } \\
\text { (mean) } \\
\text { depth } \\
\text { (feet) }\end{array}$ & $\begin{array}{l}\text { Number } \\
\text { of wells }\end{array}$ & $\begin{array}{c}\text { A verage } \\
\text { (mean) re- } \\
\text { ported yield } \\
\text { (gallons per } \\
\text { minute) }\end{array}$ & $\begin{array}{l}\text { Number } \\
\text { of wells }\end{array}$ \\
\hline $\begin{array}{l}\text { Granite gneiss } \\
\text { Gneiss } \\
\text { Schist }\end{array}$ & $\begin{array}{l}\text { 122. } 5 \\
\text { 131. } 4 \\
109.7\end{array}$ & $\begin{array}{l}54 \\
73 \\
23\end{array}$ & $\begin{array}{l}\text { 13. } 0 \\
\text { 12. } 3 \\
\text { 13. } 9\end{array}$ & $\begin{array}{l}35 \\
50 \\
16\end{array}$ \\
\hline
\end{tabular}

These figures indicate that the three rock type are about equal as aquifers, although the ratio of yield to depth is most favorable in schist. Cushman, Allen, and Pree (1953), however, present data from southern New England which suggest that granite gneiss is by a slight margin the most favorable aquifer. The authors note, though, that the differences among the rocks are not great, as shown in the table below:

Yields from all types of wells

\begin{tabular}{l|r|r|r}
\hline Rock type & $\begin{array}{r}\text { Average } \\
\text { (mean) depth } \\
\text { (feet) }\end{array}$ & $\begin{array}{r}\text { Average (mean) } \\
\text { reported yield } \\
\text { (gallons per } \\
\text { minute) }\end{array}$ & $\begin{array}{r}\text { Number of } \\
\text { wells }\end{array}$ \\
\hline Granite gneiss & 175 & 11.7 & 156 \\
Gneiss & $\begin{array}{r}9.0 \\
10.3\end{array}$ & 211 \\
Schist. & 125 & 37 \\
\hline
\end{tabular}

Cushman (written communication) also concludes from a study of 104 wells in parts of the eastern highland of Connecticut that "drilled wells in granite gneiss may have slightly higher yields than wells in schist."

For purposes of comparison, the data collected by the writer are summarized below in the same form as that from the reports of Ellis (1909) and Cushman, Allen, and Pree (1953). 
Yields from all types of wells

\begin{tabular}{|c|c|c|c|c|}
\hline Rock type & $\begin{array}{l}\text { A verage } \\
\text { (mean) } \\
\text { depth } \\
\text { (feet) }\end{array}$ & $\begin{array}{l}\text { Number } \\
\text { of wells }\end{array}$ & $\begin{array}{c}\text { A verage } \\
\text { (mean) re- } \\
\text { ported yield } \\
\text { (gallons per } \\
\text { minute) }\end{array}$ & $\begin{array}{l}\text { Number } \\
\text { of wells }\end{array}$ \\
\hline $\begin{array}{l}\text { Gneiss (mostly granite gneiss) } \\
\text { Schist }\end{array}$ & $\begin{array}{l}133 \\
198\end{array}$ & $\begin{array}{l}29 \\
12\end{array}$ & $\begin{array}{l}10 \\
17\end{array}$ & $\begin{array}{l}26 \\
10\end{array}$ \\
\hline
\end{tabular}

The above comparisons show that the water-yielding capacities of gneiss and schist are variable but on the average very nearly equal. The Collinsville gneiss of Rodgers and others (1956) may be less favorable than the schist and gneiss in the Hartland formation, but the difference is probably slight.

Data collected for this report suggest that, in general, the preTriassic crystalline rocks are a little less favorable than rocks of the Newark group as sources of water for domestic and farm wells. They may be substantially less favorable as sources for commercial or industrial supplies of 25 to $100 \mathrm{gpm}$. The Pleistocene ice-contact deposits are clearly superior to both types of bedrock as sources of large supplies.

\section{NEWARK GROUP}

The Newark group, as defined by W. C. Redfield (1856), includes the Triassic rocks that underlie the Central Lowland of Connecticut and Massachusetts as well as similar rocks in several other sedimentary basins in Eastern United States. A detailed study of the lithology of the Newark group of Connecticut was made by Krynine (1950), and though he did not work north of southern Plainville and Bristol, much of the information in this report on the lithology and thickness of these rocks was summarized from his paper. Information was also obtained from the "Preliminary Geological Map of Connecticut" (Rodgers and others, 1956), and some observations were made by the writer.

\section{AREAL DISTRIBUTION AND THICKNESS}

The rocks of the Newark group underlie all the Farmington-Granby area east of the western upland. The boundary between these rocks and the crystalline rocks of the western upland is shown on plate 1 . According to Wheeler (1937), the boundary is a fault line through most of Granby and also south of Unionville. Stream valleys were carved along most parts of the boundary zone, but the contact is concealed almost everywhere by glacial drift and its position must be inferred from well logs and geomorphology.

The rocks of the Newark group dip eastward at an average angle of $15^{\circ}$ (Krynine, 1950, p. 117), although steeper and gentler dips may 696-293 O-64-3 
each be measured at many sites. Accordingly, the Newark thickens eastward, from a featheredge along unfaulted parts of its contact with crystalline bedrock to an estimated 6,700 to 8,400 feet (totaled from generalized stratigraphic section by Krynine, 1950, p. 32) in eastern Farmington.

The Newark group consists largely of sedimentary rocks, but it also includes some igneous rocks which, because of their resistance to erosion, form prominent hills or ridges. These igneous rocks, commonly known as trap rocks, include three lava sheets and an extensive intrusive unit.

The lower of the three lava sheets may be found along the lower slopes of the ridge on the east side of the Farmington lowland. Krynine estimates it to be 100 to 250 feet thick in central Connecticut, but it thins northward and may pinch out entirely at about the East Granby-Suffield line. The middle lava sheet is estimated by Krynine to be 300 to 500 feet thick in central Connecticut. It is the most resistant unit within the Newark group and caps the high ridge that forms the east side of the Farmington lowland, thus marking the eastern boundary of the Farmington-Granby area everywhere north of Farmington. The upper lava sheet is estimated by Krynine to be 50 to 150 feet thick. Within the Farmington-Granby area, the upper sheet is found only in extreme eastern Farmington where, repeated by faulting, it forms two ridges.

The outcrop areas of these lava sheets are shown on the "Preliminary Geological Map of Connecticut." As each dips eastward concordantly with the sedimentary sequence, wells drilled just east of the outcrop area of any particular lava sheet would likely penetrate that sheet beneath the sedimentary rocks.

The intrusive igneous rocks form what amounts to a single ridge, locally interrupted by narrow stream gaps or broader drift-filled valleys. The south end of this ridge, except for an isolated hill east of Unionville, is west of State Route 167 about 0.5 mile north of the AvonFarmington line; from there the ridge extends almost due north, very close to or locally at the west border of the Newark group (Wheeler, 1937). At Firetown Road in Granby, the ridge, known here as the Barndoor Hills, swings northeastward toward Granby center. There it turns northward again, forming Manitook Mountain. North of Manitook Mountain, the ridge of intrusive rock swings northeastward, as indicated by two small knobs southeast of Congamond Lakes, and continues northward as Huckleberry Mountain in Suffield. The trap rock intrusive is not shown north of Manitook Mountain on the "Preliminary Geological Map of Connecticut." The hills it forms, however, appear as areas of ground moraine amid an expanse of stratified 
drift on the surficial geologic map accompanying the present report. According to Rice (Rice and Gregory, 1906, p. 186), following Davis (1898), this trap rock intrusive occurs as a sheetlike body, or sill, extending nearly parallel with the associated strata. Wheeler (1937, p. 31) refers to it as a sheet of variable thickness which changes from a dike in some places to a sill in others and which at the surface is inclined eastward or southeastward $10^{\circ}$ to $60^{\circ}$. Exposures observed by the writer on the north and west sides of Manitook Mountain reveal that here the trap rock is a tabular or lenticular body at least 150 feet thick, which dips southeastward at an inclination similar to that of the sedimentary rocks. Wells drilled just east or southeast of the outcrop area of this unit would probably penetrate it beneath the sedimentary sequence.

LITHOLOGY

SEDIMENTARY ROCKS

Several types of sedimentary rocks are found within the Newark group: conglomerate, white and gray to red arkose, "redstone" (red clayey feldspathic sandstone), red, dark- to light-gray, bluish-gray, greenish-gray, and black siltstone and shale, and very small amounts of limestone. Krynine (1950, p. 73-6) shows that these sedimentary rocks are made up of three petrographic (and textural) end members, mixed in various proportions:

1. A coarse-grained (sandy or pebbly) arkosic *** detritus that has essentially the following average mineral composition:

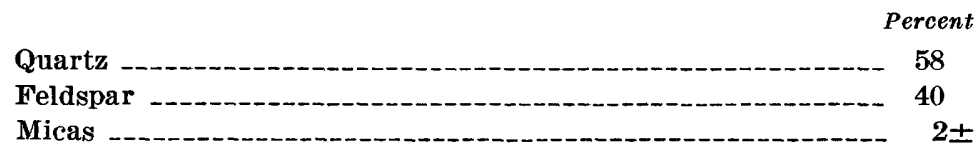

2. A fine-grained detrital clayey matrix consisting of "clay," either colorless or in most cases stained a very dark red color by hematite or in some cases, black by organic matter. This clayey matrix has the following average mineral composition :

\begin{tabular}{lr} 
Kaolin & $\begin{array}{r}\text { Percent } \\
\text { Gibbsite }\end{array}$ \\
Sericite-illite-paste & $60-$ \\
Hematite $-\ldots+$ & $12 \pm$ \\
\hline
\end{tabular}

And in addition up to 20 or 30 percent of fine-grained quartz and feldspar.

3. A chemical carbonate cement, generally calcite.

Aecording to Krynine (1950, p. 79), the sorting of the Newark sediments is on the whole fair to poor, the best sorting being shown by the pale arkoses. A study by Heald (1956) of 72 thin sections of 
Triassic arkoses from Connecticut and Massachusetts confirmed Krynine's determination of the makeup of the detrital end member, but concluded that secondary feldspar, principally albite, was more important than calcite as an authigenic mineral within the arkoses.

Krynine (1950) divides the Newark group into three formations: the New Haven arkose, including all rocks below the three lava sheets; the Meriden formation, including the three lava sheets and the two sequences of sedimentary strata between them; and the Portland arkose, including the entire sequence above the lava sheets. Only the first two of these units occur within the Farmington-Granby area. The New Haven arkose consists primarily of two rock types: a coarse, locally pebbly, gray or white to red arkose, and a fine-grained clayey feldspathic red sandstone. Although these two rock types are interbedded, the arkose predominates in the lower part of the formation, whereas the fine-grained sandstone makes up most of the upper part. Red siltstone and shale also occur, increasing in abundance upward. Krynine estimates the New Haven arkose to be 5,200 to 6,300 feet thick in central Connecticut. In the Farmington-Granby area, this formation occurs west of the base of the Talcott Mountain ridge and underlies the Farmington lowland.

The lower sedimentary unit of the Meriden formation of Krynine (1950), which occurs between the lower and middle lava sheets, consists of finely laminated shale and siltstone, dominantly red or maroon in color but containing a dark-gray zone midway in the lower half. Krynine estimates the thickness of these beds to be about 300 feet in central Connecticut. In the Farmington-Granby area, they occur only along the lower slopes of the Talcott Mountain ridge.

The upper sedimentary unit of the Meriden formation of Krynine (1950) is similar in composition but somewhat coarser; it consists of finely laminated shale, sandy siliceous shale, and siltstone, all of which are dominantly red, but it includes in the upper part a complex sequence 50 to 150 feet thick of black, blue, and gray shale containing arkose, rare dark limestone, and red shale. The upper sedimentary unit is estimated by Krynine to be 750 to 900 feet thick. Within the Farmington-Granby area, this unit is present only in eastern Farmington.

\section{IGNEOUS ROCKS}

The igneous rocks within the Newark group include lava sheets and intrusive bodies. According to the "Preliminary Geological Map of Connecticut" (Rodgers and others, 1956), the igneous rocks are black to bluish black; they grade from basalt near contacts to dolerite (diabase) in the interiors of lava sheets and intrusive bodies; they are composed of augite, labradorite, accessory magnetite, and, locally, 
olivine; and they commonly have diabasic texture. The intrusive rocks are normally massive with very well developed columnar jointing perpendicular to contacts. The interiors of the lava sheets are massive and commonly show fairly good columnar jointing. The upper parts are commonly vesicular, and both the upper and lower parts may show flow brecciation.

\section{STRATIGRAPHIC RELATIONS}

The rocks of the Newark group are interpreted on the basis of fossil evidence as being Late Triassic in age (Krynine, 1950, p. 15; Colbert, 1946).

The rocks of the Newark group rest unconformably upon crystalline rocks of pre-Triassic age similar to those exposed in the western upland. No exposures of this unconformity have been noted within the Farmington-Granby area, although it is exposed not far to the south, at Roaring Brook in Southington. However, on the east side of the Roaring Brook valley in Avon, north of Country Club Road, gneiss is exposed at an altitude of nearly 400 feet. Wheeler (1937, p. 28-29) regarded this exposure as "essentially a freshly stripped basement surface." In 1960, a new road in a housing development a few hundred feet northeast of the gneiss exposure cut into red arkose at an altitude of 400 to 420 feet. Well A 90, located several hundred feet south of these exposures on the north side of Country Club Road at an altitude of 380 feet, was reported in the driller's records to pass from "red rock" into "granite" at a depth of 103 feet. A well no more than 300 feet west of A 90 was reported by the driller to have penetrated only crystalline rock, and field examination of the drill cuttings by the writer confirmed this report.

No deposits are known to overlie the Newark group within the Farmington-Granby area other than those laid down during and after Pleistocene glaciation.

\section{WATER-YIELDING PROPERTIES}

Water in the sedimentary rocks of the Newark group occurs in intergranular pore spaces, along bedding-plane partings, and, probably most important, in joints. In the trap rocks, water occurs principally in joints but may also occur to some extent in vesicular openings in the upper parts of each of the lava sheets.

The porosity generally is small even in the arkose beds, which are the best sorted of the Newark sediments. Heald (1956) made several measurements of porosity of Triassic arkoses in thin section by the point-counter method, counting from 500 to 1,000 points for each sample. The porosity of 21 samples of medium- to coarse-grained 
normal arkose (that is, arkose not near an igneous body or major fault) from Connecticut ranged from less than 1 percent to 10 percent. The median porosity was 5 percent and the mean nearly 5 percent. Samples of arkose from the immediate vicinity of faults or igneous bodies generally showed somewhat lower porosity. This evidence indicates that the spaces between the grains of the arkosic detritus are largely filled with clayey matrix and cement. In the poorly sorted "redstone" (fine-grained clayey feldspathic sandstone), siltstone, and shale that underlie much of the eastern part of the Farmington-Granby area, the proportions of clayey matrix and cement are even higher. Accordingly, whereas pore spaces in the Newark sediments may be quite important in the aggregate for storing water, the intergranular permeability is probably so small that the contained water will not flow readily into wells.

The intergranular porosity of the Triassic igneous rocks is probably less than 1 percent (Gregory, 1909; Cushman and others, 1953) ; however, the upper parts of each of the three lava sheets are commonly vesicular (Rodgers and others, 1956), and in such zones the porosity may be appreciably larger. No information is available on the degree of interconnection of the vesicles, which would determine the permeability of the vesicular zones.

Secondary tabular openings, which are larger-although far more widely spaced-than intergranular pores, provide avenues for water movement. They include bedding-plane partings in the sedimentary rocks and, more important, the joints and faults found in all the rock types. (See fig. 6.) Most joints dip steeply, typically at angles of $70^{\circ}$ to $90^{\circ}$ from the horizontal, and many of them are perpendicular or nearly perpendicular to the bedding. Gregory reports (1909, p. 111-112) that joints are more numerous in the igneous rocks than in the sedimentary strata, principally because the joints formed in all rock types by broad earth deformations are supplemented in the igneous rocks by many joints formed as the rocks cooled from the molten state.

Several lines of evidence suggest that tabular openings in the Newark group are of paramount importance in yielding water to wells. In many roadcuts and other exposures, water may be observed seeping from bedding-plane partings or joints, but never oozing out of the rock itself. (See fig. 5.) Drillers have occasionally reported drilling into "seams" or fissures-a few of them large enough to cause the string of tools to drop abruptly-from which copious flows of water were obtained. Several fissures of this sort were reported in the well records collected for this report. Even more commonly, drillers report wells in which all or part of the yield was obtained from some 


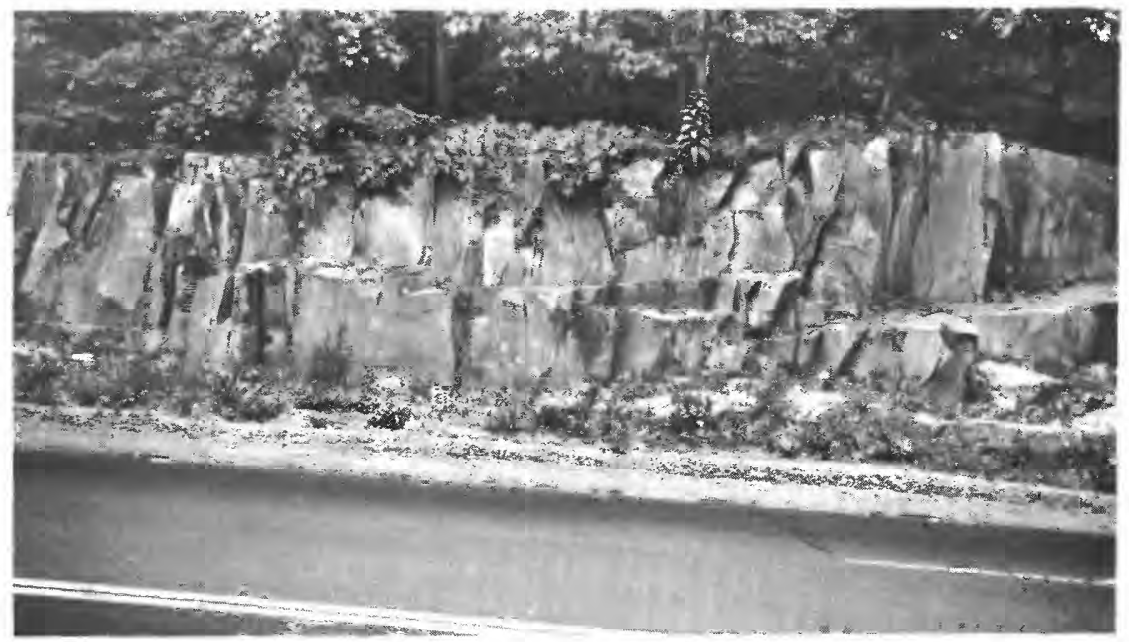

Figure 6.-Outcrop of igneous rock of the Newark group, showing well-developed vertical and horizontal joints. The rock is part of the middle lava sheet. This outcrop is along U.S. Highway 6 where it cuts one of many small bedrock knobs that protrude through the ground-moraine deposits. Location : $\mathrm{H6}$-5ba.

specific depth or narrow range of depth, indicating widely spaced narrow openings. Furthermore, some wells are reported to have penetrated many feet below the water table without obtaining even enough water for drilling, which would be most unlikely if the strata penetrated had appreciable intergranular permeability. Several wells of this sort were visited during this investigation, among them some finished in the lower part of the Newark group, which is dominantly arkose. Some wells have intersected a major fracture or fracture system already tapped by another well, as shown by the fact that pumping one well promptly lowers the water level in the other. Water in the original well is commonly reported to have become muddy when drilling of the second well reached the level of the fracture.

A total of 359 wells finished wholly or partly in the Newark group in the Farmington-Granby area were studied. Forty-nine were commercial, industrial, institutional, or public-supply wells; the remaining 310 were domestic or farm wells. Two domestic wells may extend through the Newark group into crystalline rocks, so they were not used in the compilation of statistical data on the next few pages. Two other wells are screened in ice-contact deposits in addition to tapping the Newark group. They were omitted from the compilations of yield and specific capacity. 
Drilled wells finished in rocks of the Newark group range in depth from 51 feet to 745 feet. There were also two dug wells 20 feet deep finisheu partly in the Newark group and partly in till. The median depth of all the wells is 155 feet; the median depth of the domestic and farm wells alone is 150 feet. The depth distribution curve (fig. 7) shows that a large number of wells are finished at depths not far below the median, from 90 to 150 feet, whereas well depths above the median are scattered over a range of 300 feet or more.

Differences in average well depth are associated with certain differences in type of overburden and in topography. These differences are illustrated in figure 7. In till-covered areas along the crest and steep west face of Talcott Mountain, well depths are dispersed fairly evenly over a wide range, but most wells are deeper than the median for the Newark group. The median depth of 26 domestic and farm wells in this area is about 245 feet. Wells drilled on the low, till-covered hills within the Farmington lowland are, on the other hand, generally shallower than the overall median. The 77 domestic and farm wells recorded from these hills have a median depth of 120 feet and show the best grouping around the median of any of the categories in figure 7. The median depth of 182 domestic and farm wells drilled in areas covered by stratified drift is $\mathbf{1 5 2}$ feet, though the depths are poorly grouped around the median. In the area of ground moraine and drumlins in eastern Farmington, the median depth of 22 wells is 150 feet. The fact that more wells are reported from depths of $150,200,250$, and 300 feet than from immediately above or below (fig. 7) may be due to a tendency to discontinue drilling at even 50-foot depths, and also to the fact that some owners remember well depths only approximately.

In order to eliminate the influence of differences in depth to bedrock on total well depth and to consider only the variations in the thickness of rock penetrated, the length of casing in each domestic and farm well finished in the Newark group was subtracted from the total depth, and the depth of the well within the rock was plotted (fig. 8) for each of the areal subdivisions discussed in the preceding paragraph. The median rock thickness penetrated is very nearly the same in 3 of the 4 areal subdivisions, and these values are grouped much more closely around their medians than the comparable values of well depths. Apparently the Newark group is about equally favorable as a source of water in each of these three areas, and the differences in average well depth shown in figure 7 are due largely to differences in average thickness of overburden. Along the crest and west face of Talcott Mountain, however, median rock penetration as 


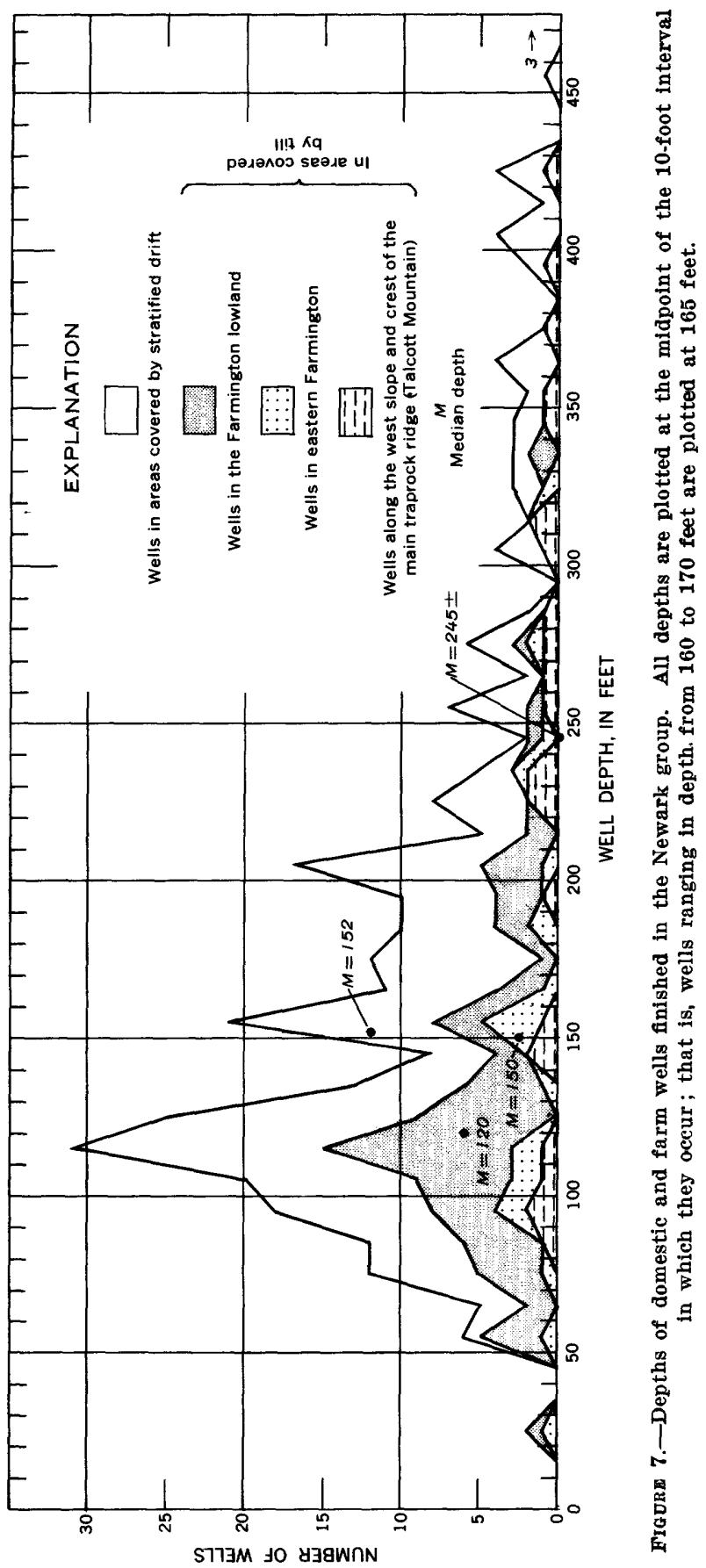




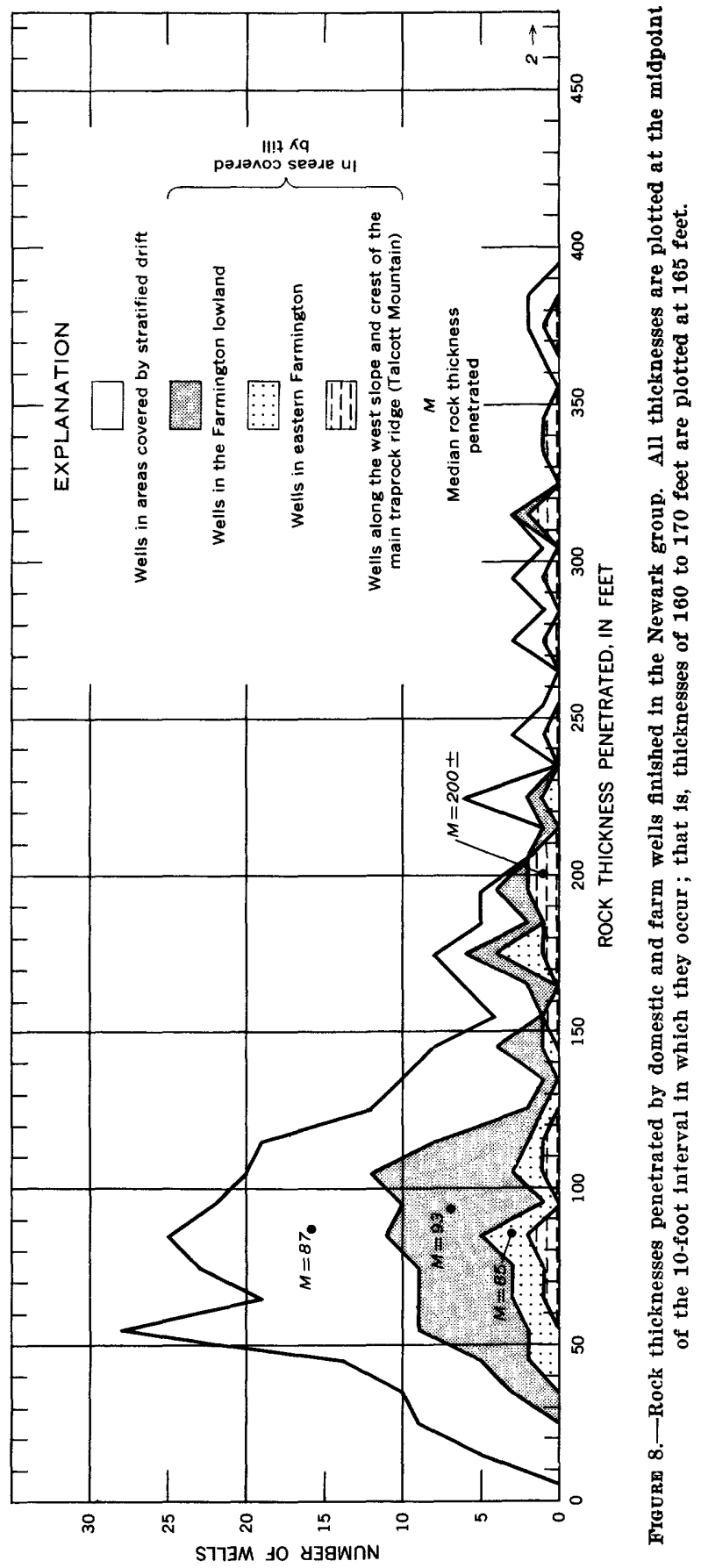


well as median well depth are unusually great, and there is very poor grouping of well depths or rock-penetration values around their respective medians. The greater well depth and rock penetration along Talcott Mountain is due in part to the water table being deeper than average near the crest of this high ridge. Also, the bedrock in the Talcott Mountain area consists of trap sheets, shale, and fine-grained sandstone of the Meriden formation of Krynine (1950) which may yield water less readily than the underlying sediments. Furthermore, some of the houses in this area are of above-average quality and the demand for water may be greater, so that wells may have been drilled deeper to obtain the desired amount. Except for the wells on Talcott Mountain, 83 percent of all recorded domestic and farm wells drilled into the Newark group in the Farmington-Granby area penetrate rock thicknesses of 10 to 150 feet. Most of the 17 percent that penetrate more than 150 feet of the Newark group were drilled through stratified drift or alluvium, but no other common characteristics of areal distribution or use were noted.

YIELDS OF WELLS

Reported yields of wells finished in the Newark group in the Farmington-Granby area ranged from virtually 0 to $500 \mathrm{gpm}$ (gallons per minute) ; the median reported yield of 312 wells was $8 \mathrm{gpm}$. One significant feature of the yield distribution is the small number of high yields. Of the 312 wells for which yields were reported, 36 (111/2 percent) had yields of 25 to $35 \mathrm{gpm}$, but only 22 (7 percent) had yields reported to be more than $35 \mathrm{gpm}$. Only 2 wells were reported to yield more than $80 \mathrm{gpm}$. One of these, well Si 51a (table 6), was pumped at $235 \mathrm{gpm}$ for 48 hours and had a drawdown of 86 feet, indicating a specific capacity of $2.7 \mathrm{gpm}$ per $\mathrm{ft}$, which, although large for the wells tapping consolidated rock in the Farmington-Granby area, is mediocre for high-capacity wells in general. Well F 18 was reported to have been pumped at $500 \mathrm{gpm}$ for 4 hours; the drawdown was not reported. This record, however, may not be completely reliable.

The reported yields of many of these wells doubtless differ somewhat from the true maximum yields. Most of the reported yields were based on bailer tests, which are only approximate. Bailer tests are ordinarily conducted for only a few minutes to a few hours, and in many wells the yield maintained over such a brief period is greater than that which could be maintained indefinitely. Conversely, in many of these wells the reported yield was measured at a pumping (or bailing) level some distance above the bottom of the well; so a somewhat larger yield probably could have been obtained if the draw- 
down had been greater. Furthermore, the maximum rate at which water can be discharged from a 6 -inch well by an ordinary bailer is only 25 to $35 \mathrm{gpm}$, so that higher yields would not generally have been reported unless a pumping test had been run. Few special tests to measure large yields were made because the great majority of the rock wells in the Farmington-Granby area were drilled for domestic, farm, or small commercial uses where large supplies were not needed.

The yields of many of the wells finished in the Newark group could probably have been increased somewhat by drilling deeper; however, the average increase in yield per foot of depth would probably decrease as well depth increased (Cushman and others, 1953, p. 90; Gregory, 1909, p. 131). Furthermore, some wells drilled to considerable depths apparently intersect few or no fractures and produce very small amounts of water. One well in the report area was drilled to a depth of 648 feet and penetrated 490 feet of rock, yet reportedly produced only $0.5 \mathrm{gpm}$.

Further evidence concerning the maximum yield normally obtainable from rocks of the Newark group is given by data for other parts of Connecticut on open file at the Middletown, Conn., office of the Branch of Ground Water. Records are available of 21 industrial wells 400 or more feet deep that were in use in or near Hartford in 1952. All these wells tap sedimentary rocks of the upper part of the Newark group (Portland arkose). The median depth of these wells is 500 feet, the median reported yield is $97 \mathrm{gpm}$, the mean reported yield is $95 \mathrm{gpm}$, and the maximum reported yield is $260 \mathrm{gpm}$. Contrasting with these are 10 wells drilled for the Connecticut General Insurance Co. in Bloomfield, Conn., which are by far the most productive group of wells completed in the Newark group anywhere in Connecticut at the time of this writing (December 1958). When tested individually for 24 hours each, these wells yielded 179 to 578 gpm and had a median yield of about $415 \mathrm{gpm}$. They too are completed in the Portland arkose. All but one were drilled to approximately 600 feet, but the driller reported obtaining very little water below 450 feet.

All this information indicates that yields of 25 to $35 \mathrm{gpm}$ are rather generally obtainable from the Newark group in the FarmingtonGranby area, and that at the majority of sites yields of about $100 \mathrm{gpm}$ can be obtained from wells of sufficient depth-perhaps 300 to 600 feet. A yield of more than $150 \mathrm{gpm}$ from a single well in the Newark group would be surprising, however, and a yield of more than $600 \mathrm{gpm}$ would be very unlikely.

Only 23 wells ( $71 / 2$ percent) of the 312 wells studied from the Newark group in the Farmington-Granby area were reported to yield 
less than $3 \mathrm{gpm}$. Accordingly, the chances probably are very good for obtaining from these rocks the yield of 3 to $4 \mathrm{gpm}$ considered desirable for an adequate domestic supply.

Specific capacity is in many ways a better measure of well performance than yield, because it takes into account drawdown as well as yield. Specific capacities could be calculated for only 137 of the wells that tap rocks of the Newark group in the Farmington-Granby area; however, the median depth and the depth-frequency curve for these 137 wells are very similar to the values based on all 359 wells finished in the Newark group; hence the 137-well sample is considered typical of the entire group of wells. The specific capacities of these 137 wells ranged from 0.001 to $23 \mathrm{gpm}$ per $\mathrm{ft}$; the median was 0.2 gpm per $\mathrm{ft}$.

The median specific capacity of 118 domestic and farm wells was $0.17 \mathrm{gpm}$ per $\mathrm{ft}$, as compared with a median specific capacity of 0.45 gpm per $\mathrm{ft}$ for 13 such wells that tap ice-contact deposits. The median specific capacity of 19 commercial, industrial, institutional, and publicsupply wells was $0.36 \mathrm{gpm}$ pr ft, which is far less than the specific capacity of any well of similar use developed in the ice-contact deposits. This comparison clearly indicates that for maximum yield with minimum drawdown, the ice-contact deposits are far more favorable than the bedrock of the Newark group.

Many of the deeper wells in rocks of the Newark group have small specific capacity, whereas large specific capacities are relatively common among the shallower wells, as shown below :

\begin{tabular}{l|r|r}
\hline $\begin{array}{c}\text { Specific capacity } \\
\text { (gpm per ft) }\end{array}$ & $\begin{array}{r}\text { Number of } \\
\text { wells having } \\
\text { less than } \\
\text { median depth }\end{array}$ & $\begin{array}{r}\text { Number of } \\
\text { wells having } \\
\text { greater than } \\
\text { median depth }\end{array}$ \\
\hline$>0.70$ & 18 & 6 \\
$.19-.70$ & 24 & 23 \\
$.06-.18$ & 21 & 23 \\
$<.06$ & 6 & 16 \\
\hline
\end{tabular}

Such a contrast is logical, because wells that obtain large supplies of water near the surface generally are not drilled deeper, whereas wells that penetrate to considerable depths before striking any wateryielding fractures would be completed in many cases as soon as a small supply is obtained. During the drilling of any given well, however, the specific capacity would normally increase whenever a new water-yielding fracture was encountered. 
FACTORS CAUSING AREAL VARIATION IN YIELD OF WELLS

Abrupt local variations in water-yielding capacity are common in the bedrock of the Farmington-Granby area. Almost any well driller can quote several examples from his experience of a well with a very high yield adjacent to a very poor well, and of considerable variation in depth among closely spaced wells. Differences in yield and depth of wells occur because the system of rock fractures is not uniform, and therefore some wells intersect major fractures at shallow depths but others do not; hence, although a given well is likely to be similar to neighboring wells, this relationship should not be depended upon.

Some broad areal variations in yield caused by geologic or topographic factors also occur. As pointed out on page 32, the Triassic igneous rocks are more fractured than the sedimentary rocks. As fractures are assumed to be the principal source of water to wells, one might expect the trap rock to be a better aquifer than the sedimentary rocks. Drillers, however, report that the trap rock is definitely less favorable than the sedimentary rocks as a source of water. Little can be said on this matter on the basis of the well records studied for this report, as only 12 wells reportedly tap only trap rock. The median depth and yield of these wells are very close to the overall medians, and specific capacities obtained for four wells in the trap rock are 0.09 , $0.1,0.1$, and $0.34 \mathrm{gpm}$ per ft. However, two important geologic factors support the drillers' view. The sedimentary rocks contain bedding-plane partings not present in the trap rock; they also have a greater intergranular porosity than the trap rock, which may be important in storing water for release to fractures. Moreover, the more resistant trap rock forms ridges, which are generally somewhat less favorable than valleys as sites for wells, principally because underground as well as surface water tends to flow away from ridges under the influence of gravity.

Drillers also report that in the areas where trap rock is present the best chance of obtaining water is at or near the contact of trap rock with the sedimentary rocks. This report is supported by data on those wells studied for this report that are known to penetrate both rock types. The reported yields of 15 such wells ranged from 4 to 67 $\mathrm{gpm}$; the median was $20 \mathrm{gpm}$. The specific capacities of 7 of these wells ranged from 0.1 to $1.3 \mathrm{gpm}$ per $\mathrm{ft}$; the median was $0.33 \mathrm{gpm}$ per $\mathrm{ft}$. In both respects these wells tended to be better than the overall average. They were also deeper than average.

One might expect that in areas of ice-contact deposits, which are generally coarser and more permeable than valley-train or groundmoraine deposits, water could percolate into the bedrock more readily, so that wells in such areas would have higher yields and specific ca- 
pacities. The records show, however, that the median specific capacity of 76 wells tapping rocks of the Newark group in areas mantled by ice-contact deposits was $0.15 \mathrm{gpm}$ per $\mathrm{ft}$, that of 12 wells in areas of valley-train deposits was $0.16 \mathrm{gpm}$ per $\mathrm{ft}$, and that of 49 wells in areas of till was $0.25 \mathrm{gpm}$ per ft. Perhaps fine-grained beds in the icecontact deposits or a basal layer of till above the rock nullify the effect of overlying permeable deposits in many places.

As soon as ground water begins to move along a fracture, chemical weathering of the rock along the fracture begins. In most fractures only a thin oxidized band develops, but along some, particularly those that have carried large flows of water, weathering is more profound and a weak or "rotten" zone results. When a drill bit intersects such a zone, a flow of dirty water commonly enters the well. These zones generally must be cased off because of the dirty water, resulting in wells with unusually deep casing. These zones, referred to as "sand seams" by drillers, occur in many places. They appear to be particularly common in one part of Granby, in which wells $\mathrm{Gr} 3,115$, 123, and 124 (pl. 1, H8-2a to -2e) intersected such zones, and the drillers report that several nearby wells likewise had done so.

\section{Pumping tests}

Brief pumping tests supervised by Geological Survey personnel were made on two wells that tap rocks of the Newark group in the Farmington-Granby area. The purpose of the tests was to determine the effect of pumping on nearby wells and to obtain data on the hydraulic characteristics of the Newark group. Records of all wells involved are given in table 6 . Well $\mathrm{F} 9$ was pumped for 274 minutes at an average rate of $67 \mathrm{gpm}$. During this test the water level in well F 9b, 178.9 feet away, declined 6.86 feet. The bedrock in the area of these wells is overlain by only a few feet of ground-moraine deposits.

Well Si 51a was pumped for 158 minutes at approximately $80 \mathrm{gpm}$. During this test the water level in well Si 113, 645 feet away, declined 12.38 feet, and the water level in well $\mathrm{Si} 79,1,515$ feet away, declined 3.89 feet. All three wells tap sedimentary rocks of the Newark group underlying 150 to 180 feet of valley-train deposits, which consist chiefly of fine sand and silt.

Water-level measurements made during these tests were analyzed by the Theis nonequilibrium formula, the derivation and use of which are described in papers by Theis (1935), Wenzel $(1942$, p. $87-89)$ and Brown (1953). Values for the coefficients of storage, transmissibility, and permeability computed from recovery data from well $\mathrm{F} 9 \mathrm{~b}$, and drawdown and recovery data from well Si 79, are as follows: 
GEOLOGY AND GROUND WATER, FARMINGTON-GRANBY, CONN.

Pumped well

F 9

Si $51 a_{\ldots} \ldots \ldots$

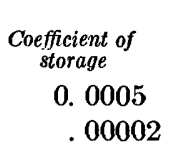

$$
\begin{aligned}
& \text { Coefficient of } \\
& \text { transmissibility } \\
& \text { (gpd per ft) }
\end{aligned}
$$
Estimated thickness of saturated

2,500

2,700
Estimated average coefficient of permeability (gpd per square foot)

210

400

The nonequilibrium formula applies ideally to a homogeneous, isotropic aquifer of infinite areal extent. Because the Newark group does not meet these assumptions very closely and because of some uncertainties in the test conditions, the coefficients computed from these two tests are only approximate. 


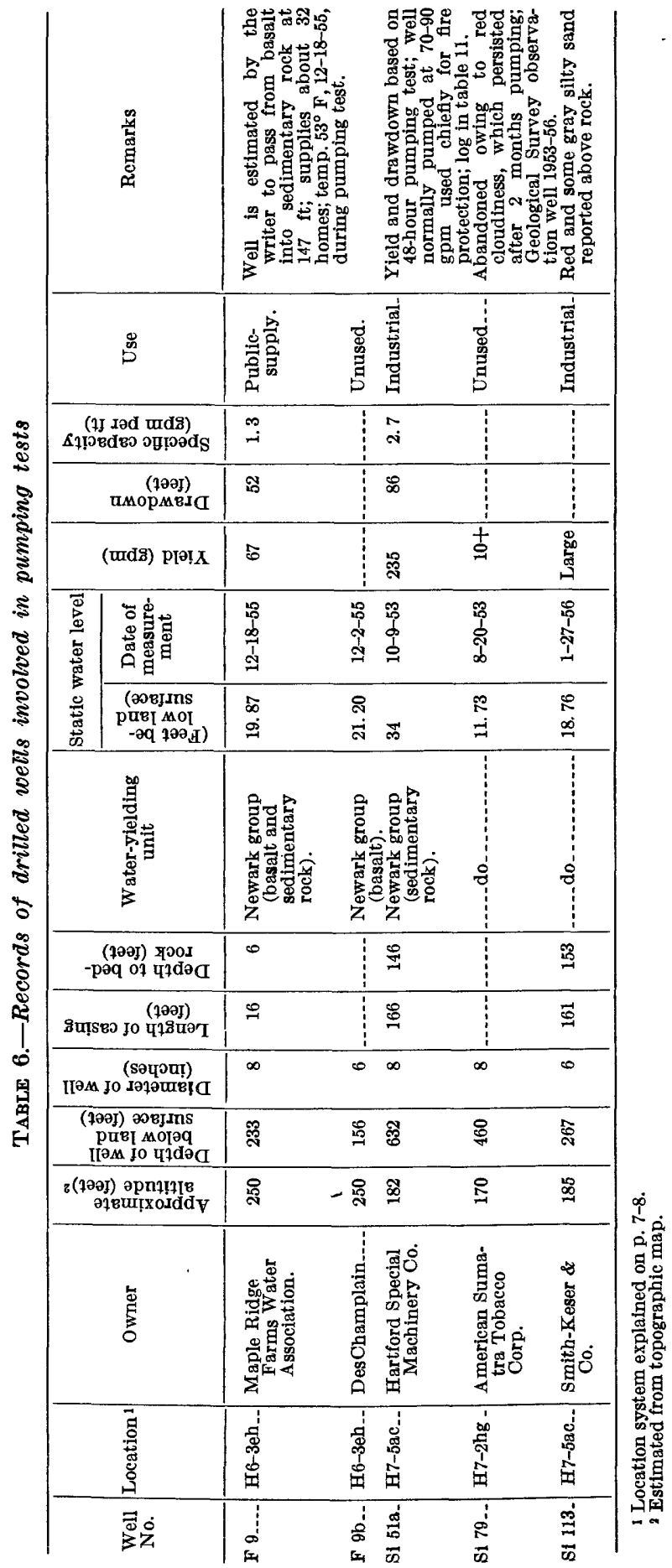




\section{UNCONSOLIDATED DEPOSITS}

A discontinuous mantle of unconsolidated deposits that is locally as much as 390 feet thick overlies the bedrock in the FarmingtonGranby area. Except for thin Recent swamp and alluvial deposits, the mantle was laid down during the Pleistocene or glacial epoch as a direct result of the great ice invasions of that time. The glacial deposits include ground-moraine, drumlin, ice-contact, and valleytrain deposits.

\section{GROUND-MORAINE AND DRUMLIN DEPOSITS}

Both ground-moraine and drumlin deposits consist almost entirely of till, which may be defined as nonsorted, nonstratified sediment deposited by a glacier. Till is believed to have been deposited partly by smearing and lodgement beneath the glacier as basal till, and partly by being gradually let down onto the land surface as superglacial till when the ice melted from around and below debris transported by the glacier. (See Flint, 1947, p. 111.) Small pockets of stratified water-laid material, which occur within masses of till in some places, are included as part of the ground-moraine and drumlin deposits.

Although ground-moraine and drumlin deposits are similar in lithology, they differ in topographic expression, distribution, manner of origin, and thickness. Accordingly, they are separated on the geologic map ( $\mathrm{pl} .1$ ) and are discussed separately, as appropriate, on the following pages.

\section{AREAL DISTRIBUTION AND THICKNESS}

Ground-moraine deposits occur at the land surface over most of the western upland, on a series of low hills along the center of the Farmington lowland, on the ridge (Talcott Mountain) that forms the east wall of the lowland, and in eastern Farmington. They form a mantle over the bedrock surface.

The ground-moraine deposits are 30 feet or less in thickness over much of the Farmington-Granby area, and bedrock outcrops protrude through them in many places; accordingly, their surface closely reflects the topography of the underlying bedrock. Thick accumulations of ground-moraine deposits occur locally, however, plastered. along hillslopes and filling a few former bedrock valleys. For example, more than 150 feet of ground-moraine deposits accumulated in parts of the bedrock valley of West Branch Salmon Brook upstream from West Granby. Thick till accumulations are also exposed at several points along the valleys of East Branch Salmon Brook and its tributary, Belden Brook, in North Granby, and 60 feet of ground- 
moraine deposits was penetrated by well Gr 148 along State Route 20 on the east flank of Bushy Hill in Granby.

Drumlin deposits are restricted to hills known as drumlins, which are smoothly streamlined, round to elliptical in plan, and commonly elongated parallel to the direction of movement of the ice. They are composed largely of till. Hills having the shape of a drumlin but composed largely of rock covered by a thin veneer of till usually are referred to as "rock drumlins," but in this report the glacial veneer on such hills is not separated from the ground-moraine deposits.

There are two major groups of drumlins in the FarmingtonGranby area, one in eastern Farmington and the other in East Granby (pl. 1). In addition, several minor knolls on a large till-covered bedrock hill in northeastern Granby and on a similar hill in southcentral Simsbury are believed to be drumlins, as is a large hill along Phelps Road in Suffield. Except for the drumlins in Simsbury, which were mapped entirely on the basis of their shape, each hill mapped as a drumlin either has been proved to consist largely of till by the record of one or more wells, or is one of a group of hills of similar orientation of which some members have been so proved. Several other hills, notably one north and another just south of State Route 20 about 2,500 feet east of the town line in East Granby, and a small hill east of Firetown Road near Simsbury center, may be drumlins; however, they were mapped with the ground-moraine deposits (pl. 1) as they lack an ideal drumlin form, are not known to be free of rock outcrops, and are not penetrated by any recorded wells that indicate the depth to rock.

As the altitude of the bedrock is little or no higher under a drumlin than under the surrounding ground moraine, the thickness of till in a drumlin is generally a little more than the height of the drumlin. Well EG 24 penetrated probably about 135 feet of overburden before striking rock, and well $\mathrm{Su} 64$ reportedly passed through 120 feet of "hardpan." The greatest recorded till thickness in a drumlin is 145 feet, at well F 89, and deposits underlying the peak of the hill on which this well is located probably are about 200 feet thick, assuming that the bedrock is at the same altitude as at the well site.

\section{IITHOLOGY}

Till, which constitutes most of the ground-moraine and drumlin deposits, consists of a mixture of gravel, sand, silt, and clay and is distinguished from all other glacial deposits by its lack of sorting. The relative proportions of the various grain sizes are by no means constant, however, and within the area of this report, till ranges in composition from chiefly clay and silt containing scattered angular 
stones to chiefly sand of various sizes containing stones and only a small percentage of silt and clay. Till having a high clay and silt content is exceedingly tough, compact, and impermeable. A high sand content, on the other hand, results in till which, although firm, is easily friable and commonly is distinctly porous. Small openings, in some places alined in indistinct planes, are easily visible upon close inspection of many exposures of sandy till.

Regional differences in bedrock lithology tend to be reflected by variations in the average grain size of the till. According to Krynine (1950), the proportion of coarse sandy detritus in his New Haven and Meriden formations decreases stratigraphically upward-which is to say eastward, because of the easterly dip. The till in the Farmington lowland shows a similar eastward decrease in sandiness, as till in the western and central parts of the lowland is sandy in most exposures, whereas relatively clayey till is more abundant along the east wall of the lowland and in eastern Farmington. In western Avon the till is generally sandy to very sandy, whereas in western Granby much of the till is compact and only moderately sandy. This grain size distinction also reflects a difference in bedrock lithology, as the Collinsville gneiss of Rodgers and others (1956) in western Avon should yield a higher percentage of sand-size detritus than the Hartland formation of western Simsbury and Granby. On the average, the sandiest till in the Farmington-Granby area is that derived from Triassic bedrock west of the Farmington River and that derived from the Collinsville gneiss. The till derived from the Hartland formation is somewhat less sandy, and the till east of the Farmington River is commonly still leșs sandy.

Although grain-size changes in the till tend to follow changes in bedrock lithology, local variations eompletely obscure this pattern in many localties. Local variations were well exposed in a series of house-foundation holes just south of Tariffville. The writer observed a very compact clayey and stony till near the brow of the bluff overlooking the Farmington River, but within 300 feet to the east the till graded to a relatively loose, sandy, porous till containing a few thin beds of sand and one of silt. Similar abrupt contrasts have been observed elsewhere. Such local variations may result from local differences in bedrock lithology and local differences in the overburden that may have rested upon the bedrock prior to the last glaciation. They may result also from variations in the process of glacial transport and deposition. Much of the sandy till at the surface may be superglacial till, which is typically looser and more sandy than basal till because it was subjected to greater melt-water sorting during deposition but not to the weight of the glacier. 
Although the ground-moraine deposits and the drumlin deposits consist almost entirely of till, they include also thin layers of stratified drift in some places. A few such layers were observed in exposures, and several dug wells were reported to have penetrated thin layers of sand within or below till. Four drilled wells were successfully completed above bedrock in areas of ground moraine, suggesting a relatively thick accumulation of sand and gravel within the ground-moraine deposits at each site-although one of these, EG 56, may be finished in a proglacial or older valley fill below the till. The $\log$ of well EG 30, on the edge of a drumlin, reports 7 feet of packed cobbles and 8 feet of loose sand and gravel below 23 feet of "hardpan." Sand also appears to underlie till in a narrow zone close to West Branch Salmon Brook upstream from West Granby. The great majority of the drilled wells, however, are not reported to have penetrated any sand within or below ground-moraine or drumlin deposits.

In several small areas, chiefly in the western upland, the groundmoraine deposits are mantled by patches of stratified drift less than 10 feet thick. These small patches of sand are not shown separately on the geologic map because of the difficulty in delineating them accurately and because the significant hydrologic characteristics of these areas are still typical of ground-moraine deposits.

\section{STRATIGRAPHIC RELATIONS}

Ground-moraine and drumlin deposits normally rest directly upon the bedrock. Exposures of ground-moraine deposits on bedrock were observed in many places, and logs of wells such as F 67 and F 74 (table 15) indicate that drumlin deposits overlie the bedrock.

Near the margins of the ice-contact deposits and valley-train deposits, a large number of exposures reveal ground-moraine deposits underlying the stratified drift. Further evidence that groundmoraine deposits are present beneath the stratified drift is provided by the logs of such wells and borings as Gr 62, Si 105, A 62, and F 105 (table 15), which pass from stratified drift into till just above bedrock. However, several reasonably detailed well logs do not report till just above bedrock, and at these sites the till may be absent owing to nondeposition or to erosion by melt water.

Till was observed to rest upon or within stratified drift in only a very few exposures. The only exposure in which two layers of till were observed was near the dump at the north end of the Avon Construction Co. pits west of Old Farms Road in Avon. It is described as follows: 
Soil zone

Till, red, very sandy ; lower contact not sharp

Sand, showing current bedding.

Gravel, fair to poor sorting, including a zone containing many angular blocks of Triassic bedrock, some as large as $2 \mathrm{ft}$ in diameter-

Sand and gravel, none finer than medium sand, in horizontal beds plus current sets dipping in various directions including $\mathrm{N} .30^{\circ} \mathrm{W}$. and $\mathrm{S} .70^{\circ}$

E. Crystalline material dominant over Triassic material

Till, red, sandy, but more clayey and bouldery than that above. Exposed only in bottom of pit.

Till was found above sand and gravel in several shallow holes in the area just north of Farmington High School (loc. H7-7gh). In a small gravel pit 600 feet south of Firetown Road, west of Bissell Brook, in Simsbury, 0.5 to 10 feet of red cobbly till overlies and in part grades into 20 feet or less of sand and gravel, and is overlain by 5 feet of gravel. A 3-foot layer of till interbedded with northwestdipping ice-contact deposits was observed in a pit just south of Tariffville. These scattered occurrences are probably flowtill (Hartshorn, 1958), unsorted superglacial material that slumped off the ice during melting. Because of their limited extent they were mapped with the stratified deposits in which they are found, although they are similar in lithology and origin to some of the till in the ground-moraine deposits.

\section{WATER-YIELDING PROPERTIES}

Because of its wide range in grain size and poor sorting, till is relatively impermeable and will not yield water rapidly to wells. Consequently, drilled and driven wells can seldom be finished in till. Many large-diameter dug wells successfully provide small domestic or farm supplies, however, because enough water is stored within their large casings to compensate for the slow rate of inflow. The pockets and layers of stratified sand or gravel that occur locally within both ground-moraine and drumlin deposits are much more permeable than till, and where such stratified layers are present below the water table they improve the water-yielding properties of the ground-moraine or drumlin deposits in proportion to their thickness and areal extent.

A total of $34 \mathrm{dug}$ wells finished entirely or partly in ground-moraine or drumlin deposits were studied for this report. These wells range in depth from 3.5 to 36 feet and have a median depth of 18.5 feet. Almost no information on the yield or drawdown of these wells is available, but they were used exclusively for domestic or farm supplies. Of the 34 wells, 8 were reported to be unfailing, whereas 12 were reported to fail or to provide an inadequate supply in a dry season.

Dug wells that penetrate sand pockets or lenses within the ground- 
moraine and drumlin deposits apparently are likely to have more adequate yields than those that do not. Of the 5 wells in groundmoraine or drumlin deposits that were specifically reported to penetrate sand layers, 2 were reported to be unfailing and none were reported to fail, whereas all 3 of the wells specifically reported to be dug entirely in till were reported to fail. More important, all 5 of the wells that penetrated a sand lens were reported to draw most of their water from that bed.

Relatively sandy till should be more permeable and yield water to dug wells more readily than relatively clayey till. Accordingly, one might expect the yields of dug wells in the Farmington-Granby area to differ according to the regional differences in sandiness of the till. If so, yields would be highest in the western part of the lowland and in western Avon, somewhat less in the western upland of Granby and Simsbury, and still less along the eastem edge of the lowland. The well records studied for this report do not show any such areal variation in yield, however. This is probably due in part to the local differences in the lithology of the deposits, which obscure the regional pattern in a great many places. Nevertheless, an individual contemplating the construction of a dug well should consider the relative sandiness of the till at the intended site.

Six drilled wells were studied that are finished in ground-moraine deposits within the Farmington-Granby area, most of them within the western upland. Wells Gr 13, 17 and $98 \mathrm{~b}$ presumably are finished in sand layers within the ground-moraine deposits, although no logs are available; the specific capacities of wells Gr 17 and Gr $98 \mathrm{~b}$ are 0.16 and $0.4 \mathrm{gpm}$ per ft. Well EG 56 may be finished in a similar layer of stratified material, or it may have penetrated a local remnant of proglacial or older stratified valley fill below the till sheet. The other two drilled wells that are finished in ground-moraine deposits, A 77 and A 106, are unusual test wells which have been abandoned. Well A 77 yielded $50 \mathrm{gpm}$ with only 3 feet of drawdown, but most of this water reportedly came from a crevice between the till and the underlying bedrock rather than from the till itself. The crevice supplied water to a large spring only 7 feet away. Well A 106 was finished in rock as well as in till; it yielded only $12 \mathrm{gpm}$ after several hours development.

These six records show that under favorable local circumstances drilled wells may obtain water from the ground-moraine deposits. In general, however, it appears that even where the ground-moraine deposits are thickest the chances of completing a drilled well in them must be classed as poor.

Driven wells also require relatively permeable deposits if they are to be successful; therefore, there is not much chance that such wells 
will be successful within the ground-moraine or drumlin deposits. Moreover, it is very difficult to drive such wells through the compact and in many places bouldery till. Only one driven well in the entire Farmington-Granby area, EG 36a, is recorded as tapping these deposits, and this well was driven down the side of a drilled well casing to tap a supply of water that had been encountered above bedrock during the construction of the drilled well. (See fig. 11.)

The lithology of the drumlin deposits in the Farmington-Granby area is similar to that of the ground-moraine deposits, and they have similar water-yielding characteristics. Certain distinctive features of drumlins however, are important to well construction and water supply: (1) the above-average thickness of the till in a drumlin probably improves slightly the small chances of a drilled well enfountering a sand lens within the till that could provide an adequate supply of water; $(2)$ as the depth to bedrock below a drumlin is greater than average, wells drilled through the drumlin deposits and finished in bedrock require unusually large amounts of casing, thereby increasing their cost; however, because of this relatively great thickness of till such wells should be exceptionally safe from pollution if the space around the casing is properly backfilled; and (3) static water levels are unusually deep in most wells finished in bedrock below drumlinsin many wells they are only slightly above the rock surface.

\section{ICE-CONTACT DEPOSTTS}

Some glacial debris was transported and reworked by melt water and laid down in moderately to very well sorted layers of gravel, sand, silt, and clay. Deposits thus formed are referred to as stratified drift. The ice-contact deposits, as described in this report, are a widespread unit of dominantly coarse-grained stratified drift, laid down in places where relatively large amounts of stagnant ice were still present at the time of deposition and therefore built against and over these remnant. ice masses. Deposits believed to have been laid down under relatively ice-free conditions away from the areas of most active melting are referred to as valley-train deposits and are discussed in a later section of this report; however, it is recognized that all gradations between ice-clogged and ice-free depositional conditions must have existed in parts of the Farmington-Granby area at one time or another, and thus the division of the stratified drift into two categories is necessarily arbitrary.

\section{AREAL DISTRIBUTION AND THICKNESS}

Although ice-contact deposits are widely distributed through the Farmington-Granby area, almost all are in lowlands. Ice-contact deposits fill the entire Lake Garda and Roaring Brook valleys and 
most of the Farmington lowland north of Granby center. South of Granby center valley-train deposits fill the deepest part of the lowland, but ice-contact deposits form a continuous band up to 2 miles in width extending eastward from the west side of the main lowland, and also cover considerable areas along the east side in Avon and East Granby. The position of the prominent sand bluff that marks the east margin of the west-side deposits for much of the distance from northern Simsbury to Farmington was apparently controlled by the bedrock topography, as this bluff lies close to the buried bedrock bluff that forms the edge of the deep Farmington bedrock valley.

The thickness of the deposits in the lowland depends more on the bedrock topography than on the surface topography. They are thickest where they overlie bedrock valleys and are thinnest over buried bedrock ridges. In the Roaring Brook valley, ice-contact deposits reportedly are 107 feet thick at well A 49 and at least 100 feet thick at well $\mathrm{A}$ 108. In the main lowland, well $\mathrm{Si} 92$ penetrated 145 feet of stratified deposits, and well Gr 79 penetrated nearly 161 feet. All four of these wells are located near the axes of major bedrock valleys. On the other hand, well Si $84 \mathrm{a}$ also is within the area of ice-contact deposits in the main lowland, but it was drilled over a buried bedrock ridge and penetrated bedrock at 20 feet.

A few of the ice-contact deposits, principally those in the western upland or eastern Farmington, are not lowland fills. Some might be described best as patches on broad upland surfaces; for example, the deposit east of State Route 189 near the Massachusetts line, in Granby, or the one west of Hawley Brook, in western Avon. Others underlie relatively narrow terraces along hillsides, such as among the hills west of West Simsbury. Some deposits in extreme eastern Farmington are fills of minor bedrock valleys. These upland deposits are generally less than 50 feet thick. Well A 92 is reported to have penetrated 88 feet of sand and gravel, but the lower part of this sequence may have been deeply weathered bedrock, which was reported in nearby well A 109. Formed high on the slopes, these deposits are not of great areal extent or thickness, because soon after deposition began the melting of ice would permit streams to shift to new courses at lower altitudes.

\section{LITHOLOGY}

SIZE AND SORTING

The ice-contact deposits consist largely of sand but contain some gravel and relatively small amounts of silt. The median grain size of a majority of the beds is at least as coarse as medium sand, as indicated by most surface exposures and well data. The deposits are by no means of uniform grain size, however. Pronounced changes in 
grain size and sorting from one bed or set to the next may be observed in many exposures; moreover, both exposures and well $\operatorname{logs}$ indicate large-scale lateral and vertical lithologic variations. Such largescale variations, or facies changes, appear to reflect differences in mode of deposition, distance from source of sediment, and depth within a deposit.

Glaciofluvial sediments-laid down by overloaded melt-water streams along shifting stream channels beside, on, or in front of the stagnant ice-show important differences from glaciolacustrine sediments, which were laid down as deltaic or bottom deposits in glacial lakes that existed temporarily during deglaciation. Cuts in glaciofluvial deposits expose poorly sorted to well sorted beds arranged in sets that are only a few inches to a few feet thick or pinch out laterally in a short distance. Sharp differences in average grain size between adjacent beds or sets are quite common, and boulders are exposed in some places. (See fig. 9.) An example of typical glaciofluvial deposits exposed in a sand pit south of Notch Road, Granby, is described as follows:

\section{Material}

Thickness (feet)

Gravel, containing cobbles and boulders up to 1 foot in diameter, coarsest in middle; includes about 40 pereent sand; fairly clean but some layers silty

Sand, occasional pebble layers, in relatively long, nearly horizontal beds containing small southward-dipping currentsets and many small unconformities

Sand and fine gravel in alternate beds; includes one 8-inch layer of very fine sand and silt.

By way of further example, the ice-contact deposits in the section from the Avon Construction Co. pits described on p. 48 are also glaciofluvial in origin. The logs of wells Si 100, Gr 93, and A 73 (tables 15 and 16) illust rate the subsurface character of the glaciofluvial deposits.

In contrast, the sediments laid down under glaciolacustrine conditions are less variable but are finer than the glaciofluvial deposits. They are composed of coarse to very fine sand that commonly contains silt layers but almost no gravel. The beds are generally well sorted, sets of uniform well-sorted beds at least 25 feet thick can be observed, and there is less variation between adjacent sets than in the glaciofluvial deposits. Deposits of glaciolacustrine origin are common along the east margin of the deposits west of the Farmington River in the lowland and probably form part of the fill of most bedrock valleys.

The grain size and sorting of the ice-contact deposits is influenced by distance from source of sediment as well as mode of deposition. As coarse particles are the first dropped by a stream when it loses velocity, 


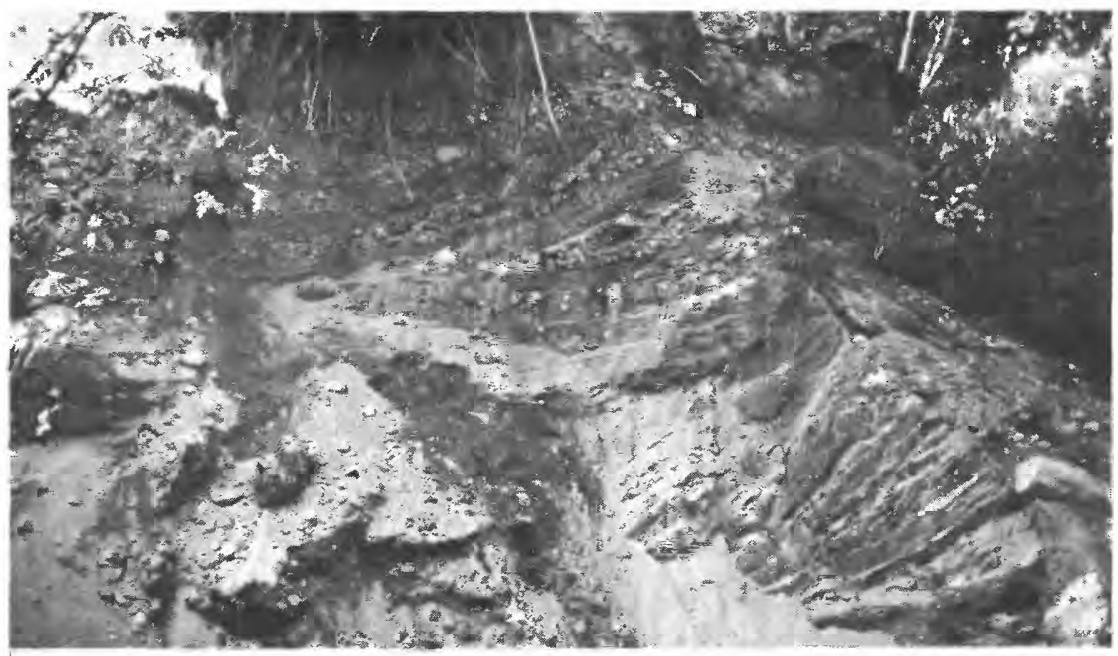

FIgURe 9.-Glaciofluvial beds in the ice-contact deposits, showing steep dips at lower right, suggesting collapse, and crossbedding. In this exposure several feet of medium and coarse sand, containing pebble stringers, are overlain by beds of coarse sand to cobble gravel, containing some boulders. (The uppermost 2 feet are wind-laid fine sand to silt.) Location: H8-4ff.

coarse sediments are not moved as far as fine sediments from their original source. The effect of this process is most noticeable among deposits laid down largely by the major streams, Salmon Brook and the Farmington River. The ice-contact deposits around River Glen and south of West Granby, near where the Farmington River and West Branch Salmon Brook, respectively, enter the main lowland, are perhaps the most consistently coarse-grained stratified deposits in the lowland. Coarse-grained ice-contact deposits are found also along these streams upstream from the main lowland. A gradual decrease in average grain size from west to east and locally from north to south in the near-surface sediment west of the Farmington River in Simsbury and Avon, and changes in terrace altitude such as mentioned on page 18 , suggest that in this area streamflow during deposition was southward and eastward.

Finally, grain size of the ice-contact deposits commonly varies with depth, particularly in major bedrock valleys. Relatively coarse surficial deposits commonly grade downward into finer deposits, which may be glaciolacustrine; coarse sediments may be encountered again, however, near the base of the section. This gradation is best illustrated by well logs. Samples from well Gr 131 (table 15) reveal that 40 feet of medium and coarse sand overlies 23 feet of well-sorted very fine sand which, in turn, overlies at least 17 feet of fine sand to 
gravel. The log of well A 108, also given in table 15, shows medium and coarse sand to 40 feet, fine sand and silt from 40 to 90 feet, and medium to coarse sand from 90 to 100 feet. The driller's log of well Gr 106a (table 15) reports passing from coarse-grained deposits into fine sand at 90 feet, but penetrating coarse sand from 120 feet to bedrock at 126 feet. Logs of such wells as Si 81d, A 13, and A 129 (tables 15 and 16), show a similar pattern. This pattern appears to be particularly characteristic of the sediments in the Roaring Brook valley and the valleys along the west side of the main lowland. In areas of rather shallow bedrock many wells penetrated only relatively coarse sand or gravel, which would correspond to the coarse upper layer commonly present in valley areas. No well drilled through ice-contact deposits is reported to have penetrated materials that steadily inceased in coarseness as the depth increased.

\section{COMPOSITION}

The ice-contact deposits in the Farmington-Granby area contain fragments of both crystalline and Triassic bedrock, and they differ considerably in lithologic character from place to place according to the proportion of each. Deposits composed almost entirely of crystalline rocks are yellow or, locally, gray, and the sand grains in them are individual mineral fragments, usually angular, that have little or no red staining. Such deposits are found in the western crystalline upland, in valleys along the contact between the Newark group and the crystalline rocks, and in parts of the main lowland where streams disgorge from the upland, such as near River Glen, West Simsbury, and West Granby.

Deposits east of the Farmington and Pequabuck Rivers, and deposits near the eastern border of the area of this report north of Tariffville, apparently were derived entirely from Triassic bedrock. In many sand beds, more than 50 percent of the grains are not individual mineral species buf rather are tiny fragments of Triassic shale, siltstone, or fine-grained sandstone. Most individual mineral fragments present are partly coated with ferric oxide or fine red silt particles, so probably were derived from Triassic bedrock. The deposits are quite red. In eastern Farmington, where outcrops of basalt are numerous, many ice-contact deposits appear to contain more than 50 percent basalt fragments, which color them red brown.

In much of the western part of the main lowland south of the Suffield town line and in virtually the entire lowland north thereof, the ice-contact deposits are made up of a mixture of detrital fragments derived from both the local Triassic bedrock and the crystalline bedrock of the upland, crystalline detritus being dominant in most exposures. The mixture developed because crystalline detritus was carried into 
the lowland by the glaciers and by streams flowing out from the upland during deglaciation.

At several localities within the western part of the main lowland, detritus derived from Triassic rocks is found below dominantly crystalline material. One example (too small to show on the map) was observed along the bluff north of State Route 4 in Unionville, about 1,500 feet east of State Route 167; another is mapped along Old Farms Road in Avon, about 1,000 feet south of Country Club Road. This relation is also shown in the log of well Si 81 (table 15), and it may obtain elsewhere in the main lowland. However, several other wells, such as A 114, Si 100, and Gr 106a (table 15), are reported not to have penetrated any detritus containing a high proportion of Triassic materials. There is no record of stratified drift derived from crystalline rocks being penetrated below stratified drift derived from Triassic rocks anywhere in the Farmington-Granby area.

Those parts of the ice-contact deposits in the Farmington-Granby area that were recognized during surface mapping as containing a relatively high percent of detritus from Triassic bedrock are distinguished on the geologic map. In general, deposits in which 10 to 20 percent or more of the grains are fragments of Triassic shale, siltstone, and sandstone, and in which a large proportion of the remaining grains are stained, have been differèntiated. This distinction is significant to users of ground water because of differences between the two groups of deposits in sorting and hence in permeability, as discussed below, and in the mineralization of ground water, as discussed in the section on chemical quality.

Deposits high in detritus from Triassic bedrock are a little less well sorted than the sediments derived from crystalline rocks. In several exposures among the red ice-contact deposits, sand was found which appeared dirty or, when wet, was somewhat gummy to the touch, owing to intestitial silt or clay. In a pit just south of Tariffville, a layer of pebble gravel was observed which was several feet thick and very well sorted except that each pebble was coated with a thin layer of clay. The Lorencik pit, near well $\mathrm{F} 80$ on New Britain Avenue in Farmington, contains a linear eskerlike deposit of poorly sorted dirty red gravel, sand, and silt, including a layer of hardpacked clayey sand, which was formerly covered by relatively wellsorted beds made up of crystalline-rock detritus. Bodies or layers of till are present among the ice-contact deposits in both these pits and also cap the deposit behind Farmington High School (location H7-7gh). By contrast, a very few thin layers of till were the only examples of extremely poor sorting observed among ice-contact deposits relatively high in detritus of crystalline origin. The presence 
of both well-sorted and poorly sorted material among the deposits in eastern Avon derived from Triassic bedrock is suggested by the logs of wells A 56 (table 15) and A 72, 73, 75, 98, and 100 (table 16).

\section{STRATIGRAPHIC RELATIONS}

Ice-contact deposits may be observed to overlap ground-moraine deposits at many exposures. A few well logs, such as the log of well A 62 (table 15), show ice-contact deposits overlying ground-moraine deposits. The ice-contact deposits are believed to be overlapped by valley-train deposits at most places where the two units are in contact, as suggested by logs of such wells as F 122 and Si 84 (table 15).

Alluvium may slightly overlap ice-contact deposits locally along the Farmington River valley south of Tariffville, and there may be a few localities east of the river where ice-contact deposits have been completely buried by the later valley-train deposits and alluvium. Ice-contact deposits are believed to be continuous beneath a thin cover of alluvium in the River Glen-Unionville vicinity and along Salmon Brook upstream from Granby center, as suggested by the logs of wells F 98c and F 100 (table 15) and by the eonsiderable depth to bedrock in these areas.

\section{WATER-YIELDING PROPERTIES}

The lithology of the ice-contact deposits, particularly the fact that in most places the average grain size of a considerable proportion of the beds is at least as coarse as medium sand, suggests that these deposits constitute a potentially favorable aquifer. Hydrologic evidence confirms this. Drilled, driven, and dug wells are finished in the ice-contact deposits through much of their areal extent, as shown on plate 1. Furthermore, most of the high-capacity public-supply, industrial, and irrigation wells in the Farmington-Granby area are finished in these deposits.

Records of 35 drilled wells that tap the ice-contact deposits were studied for this report; 19 of them have screens. Their depths range from 30 to 173 feet, excluding two wells that continue into bedrock, and the median depth is 80 feet. Their reported yields range from $3 \mathrm{gpm}$, in two wells without screens, to 1,200 gpm-the largest yield of any well in the Farmington-Granby area. The median reported yield is $30 \mathrm{gpm}$. Specific capacity could be calculated for only 20 wells. Seven public-supply, industrial or irrigation wells had specific capacities of $46,31,24,18,13,8$, and $5 \mathrm{gpm}$ per $\mathrm{ft}$. Specific capacities of 13 domestic or farm wells ranged from 0.06 to $50 \mathrm{gpm}$ per $\mathrm{ft}$; the median of these was $0.45 \mathrm{gpm}$ per $\mathrm{ft}$, and the mean-excluding the one unusually high value of 50 -was $1.8 \mathrm{gpm}$ per ft. Of the 6 domestic 
and farm wells with specific capacities above the median, 4 have screens, whereas only 2 of the 6 below the median have them.

The drillers of five other wells that were studied for this report stated that these wells could have been finished successfully in the ice-contact deposits but nevertheless were drilled into bedrock. Logs of these wells, Gr 93, 105, and 106a, F 80, and F 113, are given in tables 15 and 16. At well $\mathrm{F} 113$, the yield of $60 \mathrm{gpm}$ obtained from the icecontact deposits was insufficient for the air-conditioning use planned, but it was greater than the $8 \mathrm{gpm}$ obtained from the bedrock. The drillers of two other bedrock wells, A 114 and Gr 119, reported that a sand or gravel well could probably be completed at these sites. Although no such reports were received regarding other bedrock wells within the area of the ice-contact deposits, probably some of these wells did penetrate beds favorable for well construction. Accordingly, the presence of one or more bedrock wells in a given area does not necessarily mean that favorable water-yielding deposits do not exist within the ice-contact deposits.

A total of 34 successful driven wells finished in ice-contact deposits were studied; they ranged in depth from 8 to 72 feet, 40 feet being the median depth. Little dependable information on yield or drawdown is available, but almost all these wells provide domestic or farm supplies that are considered adequate by the owners. Fourteen smalldiameter jetted wells put down to test for public water supplies were also studied. Their depths range from 15 to 200 feet. Yields of 125, $85,75,75,60,35,30,15$, and $21 / 2 \mathrm{gpm}$ were reported by the drillers for 9 of these wells.

Twenty-six dug wells finished in ice-contact deposits were studied for this report; they range in depth from 8 to 36 feet and have a median depth of $191 / 2$ feet. Little dependable information on yield or drawdown is available, but at least a few of them are apparently very productive. Well Si 66 was reportedly pumped at $90 \mathrm{gpm}$ for 45 minutes, by which time the water had been lowered 5 feet, to the bottom; it was reported that the well could be pumped "indefinitely" at a rate of $25 \mathrm{gpm}$. Well A 19a reportedly had a drawdown of 9 feet after being pumped at $500 \mathrm{gpm}$ for 4 hours, indicating a specific capacity of about $55 \mathrm{gpm}$ per $\mathrm{ft}$. Well A 24 had about 2 feet of drawdown after being pumped at $200 \mathrm{gpm}$ for several hours, indicating a specific capacity of about $100 \mathrm{gpm}$ per $\mathrm{ft}$.

Although the ice-contact deposits are generally favorable as a wateryielding unit, variations in saturated thickness, grain size and sorting, and lithologic composition locally limit yields.

In many localities the saturated thickness of the ice-contact deposits is small because the water table is deep, at least seasonally, or the de- 
posits are thin. This is true of virtually all the deposits in the western is upland, most of those among the numerous till-covered hills in northcentral Simsbury, and others in various minor valleys throughout the Farmington-Granby area.

Variations in grain size and sorting also influence the water-yield"ing potential of the ice-contact deposits, as both coarse texture and "good sorting promote increased permeability. The causes and distribution of such variations arediscussed under "Lithology," above. The coarsest ice-contact deposits in the Farmington-Granby area are proba. ably those near where Salmon Brook and the Farmington River enter the main lowland, and upstream along the Farmington River. Deposits along the sides of the main lowland tendato contain more coarse material than average and, except for those containing abundant Triassic detritus, are more permeable than average. In the major bedrockewalleys, the upper part of the ice-contact deposits contains permeable beds, and commonly a permeable-layer is found just above the bedrock, but the.middle of the section in many places consists largely of fine and very fine sand and silt of low permeability. Along the east margin of the deposits west of the Farmington River, relatively little coarse sand and gravel is present, but the deposits are better sorted than average and in places are very permeable.

Screened wells can be finished in any reasonably well-sorted saturated deposit from gravel to medium sand size and even in wellsorted fine sand if careful construction and development techniques are used. Accordingly, screened wells can probably yield at least small supplies of water in most areas of ice-contact deposits where there is sufficient saturated thickness. Local variations in grain size and sorting are an important factor controlling the maximum yield obtainable, however, and test drilling is usually necessary to select the best site for a large-capacity well. Because the sediments grade downward from coarse to fine to coarse again in many areas, all testing should proceed to bedrock.

The only extensive area where ice-contact deposits may be mostly too fine grained for screened wells is the delta area south of Farmington Station and east of Scott Swamp Brook. Even here, however, coarse sediments are present locally at the base of the section.

Wells finished with an open-end casing, on the other hand, normally require relatively coarse stratified deposits to yield water rapidly without becoming filled with sand. Such coarse materials are not present below the water table everywhere. The chances of being able to finish a well in this manner are best in the coarser deposits referred to above. 
Because the ice-contact deposits mapped as high in Triassic detritus are generally a little less well sorted than other ice-contact deposits, they are not quite as favorable for well construction. This is particularly true of deposits east of the Farmington River within the main lowland. The layers of till and poorly sorted stratified drift present among these deposits are themselves too impermeable for finishing wells and tend also to reduce the overall permeability of the deposits in which they occur. In addition, the coatings of fine sediment commonly observed on sand and gravel grains might gradually enter the well unless removed by careful development. Well A 72 (table 16) was reported to have pumped a considerable amount of brown mud when first constructed in 1951, and a little each spring thereafter-at least through 1954. It should be emphasized that a number of successful wells tap ice-contact deposits composed of Triassic detritus, notably $\mathrm{Si} 37$, which yields $265 \mathrm{gpm}$ and has a specific capacity of $24 \mathrm{gpm}$ per $\mathrm{ft}$. Nevertheless, these deposits present certain problems of well construction to a greater degree than similar deposits containing more crystalline-rock detritus.

\section{VALIEY-TRAIN DIPOSTTS}

The valley-train deposits are dominantly fine sediment laid down under fluvial and, in part, lacustrine conditions in valleys that were relatively free of melting ice. They occur chiefly below an altitude of 210 feet.

\section{AREAL DISTRIBUTION AND THICKNESS}

The valley-train deposits are considerably less extensive than the ice-contact deposits, being confined to relatively narrow bands along the Farmington and Pequabuck Rivers, the lower reaches of Salmon Brook, and two tributaries of Salmon Brook. They occur exclusively as valley fill, and over much of their areal extent are bordered by icecontact deposits that lie along the sides of the valleys.

The valley-train deposits underlie many constructional terraces, most of which apparently were once more extensive, that are scattered along the major streams from one end of the Farmington-Granby area to the other. The surfaces of these terraces are at altitudes of 195 to 220 feet. Other terraces, generally smaller, lie at altitudes of 160 to 180 feet along the Farmington River between Farmington center and Tariffville. Surface exposures and well logs, such as the log of well Si 109 (table 15), indicate that the lower terraces are underlain by the same materials as the higher valley-train terraces. They are interpreted as erosional terraces which were cut by the river chiefly in the valley-train deposits and are thus mapped with them.

696-293 $0-64-5$ 
The maximum known thickness of the valley-train deposits is about 390 feet. Because they are largely restricted to relatively deep bedrock valleys, their average thickness is greater than that of the ice-contact deposits, despite the lower altitude of their top surfaces.

\section{IITHOLOGY}

The valley-train deposits range in grain size from pebbly coarse sand to clay, with fine sand, very fine sand, and silt predominating. A thick unit of chiefly fine sediment constitutes the bulk of the deposits and is overlain in most places by a relatively thin upper layer of medium and coarse sand containing scattered pebbles. (See fig. 10.)

The upper unit of pebbly medium to coarse sand is typically 5 to 25 feet thick but is locally as much as 40 feet thick. It exhibits fluvial cut-and-fill crossbedding wherever exposed, and normally the contact with the lower unit is an erosional unconformity. This unit appears to have been largely removed by erosion in areas of alluvium, but in some of these areas the lower part of the alluvium consists of similar coarse fluvial material.

The lower unit differs in thickness from place to place according to the irregularities in the bedrock surface; the maximum known thickness is nearly 380 feet. Where exposed, it consists of fine sand, very fine sand, and silt. It exhibits horizontal bedding, some foreset bedding-including relatively thin horizontal layers of foreset beds

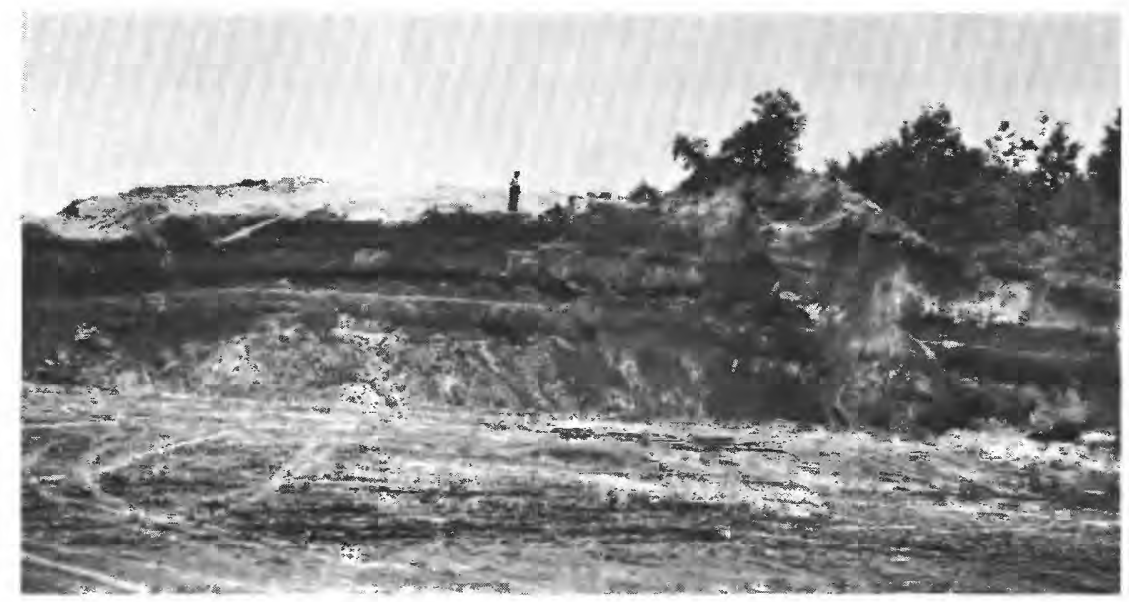

Figure 10.-Lower unit of the valley-train deposits exposed on the north side of Round Hill, Farmington (location $\mathrm{H} 6-\mathbf{f e}$ ). The dark layers are red clay and silt, containing one mass of cobbles (at arrow); the lighter layers are gray fine sand to silt, ripple marks and current sets being present in some layers. Several feet of medium sand to pebble gravel formerly capped the hill, above the level on which the children are playing. 
(current sets) - and current-ripple marks. These characteristics suggest deposition in a broad flood plain or a shallow lake.

The subsurface part of the lower unit consists very largely of finegrained sediments, chiefly very fine sand and silt. This is particularly true from Avon center north to Granby center, as shown by the logs of many wells and borings, such as Si 51, 103-105, and 129, and EG 38 (table 15). South of Avon center, coarser layers were penetrated at depth in several wells, but the deposits still are mostly fine grained. Samples from the well at the Trumbull Electric Co., in Plainville, show a sequence-very similar to exposures of the lower unit at Round Hill in Farmington (fig. 10) -in which thick layers of gray fine sand alternate with thin layers of red and gray clay down to an altitude of -25 feet.

Because the valley-train deposits between Farmington center and Granby center were laid down later than adjacent ice-contact deposits, they may include some relatively coarse grained sediment eroded from the ice-contact deposits and deposited in the areas where local streams disgorge. North and west of Granby center, some of the deeper beds below the valley-train terraces are coarse grained. These deeper beds were probably laid down at a relatively early date when there was still much ice nearby. The stratified drift below the alluvium becomes coarser westward along State Route 4 from Farmington center to River Glen, and deposits coarse enough to yield water to wells are present about 0.2 to 0.3 mile east of the south end of Brickyard Road. It is possible that the coarser deposits near River Glen are all part of the valley-train sequence, becoming coarser toward the source, but the writer believes that the coarse sediments to the west may be ice-contact deposits that have been planed off by erosion.

In most places, the upper unit of the valley-train deposits is composed almost entirely of detritus from crystalline rocks. The lower unit in Farmington and Granby is also composed largely of such detritus, which suggests that in these towns the Farmington River and Salmon Brook, both of which drain areas primarily of crystalline rock and of glacial drift derived therefrom, contributed a large part of the sediment. In Avon and Simsbury, however, most of the lower unit is described as red, reddish brown, brown, or grayish brown rather than gray, although the gray component does become dominant toward the top of the sequence. The relatively high proportion of detritus from Triassic rocks in the sediments of this area suggests that these sediments may have been derived largely from melting ice in the lowland. Triassic detritus is dominant in both upper and lower units near the upstream end of the deposits along Muddy Brook in East Granby, an area which was not part of the main drainage flow. 


\section{STRATIGRAPHIC RELATIONS}

Valley-train deposits were observed to overlap till at several exposures. They also overlap ice-contact deposits at most points where the two units are in contact. (See plate 2.) Valley-train deposits were observed overlying red ice-contact deposits in several roadcuts along the east side of the lowland north of Farmington center. Several small hills of red ice-contact deposits are nearly surrounded by valley-train deposits just east of the Farmington River and north of U.S. Highway 44 in Avon. Lougee (1938) shows a picture of 6 feet of crossbedded yellow sand and gravel overlying foreset beds of red gravel east of the Pequabuck River three-eights of a mile north of the Farmington-Plainville town line, and there may be a few other points along the east side of the lowland where red ice-contact deposits have been entirely buried below valley-train deposits. Overlap is more difficult to observe along the western side of the lowland because of the lithologic similarity of the surface exposures, but the $\operatorname{logs}$ of wells F 123 and Si 84 (table 15) are interpreted as illustrating this relation. However, well F 52 (table 16) is in a similar position but records no such relation.

The valley-train deposits are overlain by a mantle of alluvium over a considerable area along the Farmington River and Salmon Brook. The alluvium is only a few feet thick, as indicated in the logs of such borings as F 120 and $\mathrm{Si} 128$ (table 15), and the valley-train deposits mapped on either side are continuous beneath it.

\section{WATER-YIELDING PROPERTIES}

It has been pointed out (p. 60) that the valley-train deposits may be divided into two lithologic units: (1) an upper, relatively thin layer of pebbly coarse to medium sand and (2) a lower sequence of chiefly fine sand to silt. Although the upper unit does not extend far below the water table in many places, well records indicate that the water-yielding properties of the valley-train deposits are generally favorable at shallow depths but much less favorable below.

Of the wells considered in this report as finished in valley-train deposits, all the dug wells, most of the driven wells, and the most productive drilled and jetted wells are relatively shallow.

The 8 dug wells range in depth from 12 to 34 feet; the mean depth is 19 feet and the median depth is 20 feet. No reliable information on vield and drawdown is available, but all these wells reportedly have provided adequate domestic supplies.

The 7 driven wells in valley-train deposits range from 17 to about ǒ feet in depth and have a median depth of 30 feet. Five of these wells are believed to be finished either in the upper unit or in rel- 
atively coarse sand layers in the upper part of the lower unit, and they are apparently successful. The deepest of the driven wells, however, well $\mathrm{F} 76$, is finished in fine to very fine sand of the lower unit; it was reportedly pumped at $6 \cdot \mathrm{gpm}$, but as it was not yet in use when visited its reliability is unknown. Also, well F 44 is reported to have been finished in fine sand and silt with a gravel-pack technique devised by the owner, which might help to explain its several years of use with no failures.

Of the 10 drilled wells studied from valley-train deposits, the shallowest, well $\mathbf{A} 29$, has by far the largest yield. This well is screened from about 21 feet to about 26 feet in depth, which would be below the base of the upper unit in much of Avoil. However, 26 feet is the total thickness of the valley-train deposits at the well site, and the entire sequence apparently is coarse grained. Jetted well A $123 \mathrm{~b}$ was an earlier test hole at the site of well A 29.

The remaining 9 drilled wells recorded as ending in valley-train deposits in the Farmington-Granby area penetrate the lower unit, as do 4 jetted test wells. Between Avon center and Granby center, the lower unit appears to be consistently fine grained and unsuitable for well construction. The four deep jetted test wells in this area were failures. Of 3 drilled wells that ended above rock in this area, 2 were abandoned as failures and the third ( $\mathrm{Si} \mathrm{78a}$ ) is finished in a basal gravel which might be of subglacial origin rather than part of the valley-train sequence. In addition, wells $\mathrm{Si}$ 51, 51a, and 78 are known to have been drilled into rock only because no suitable deposits were penetrated in the valley-train deposits above. Logs of several other wells and borings in the area report fine-grained materials.

Southward from Avon center records of drilled wells show the lower unit to be slightly more favorable. Well A 25, near Nod Brook, was finished with a screen at 50 feet and reportedly yielded $10 \mathrm{gpm}$ in 1915 . Drilled wells F 3 and F 46a were both finished successfully with openend casing, the former reportedly yielding more than $30 \mathrm{gpm}$ with little drawdown. Although the driller of well F 118 reported the valley-train deposits as unfavorable, mudpit samples from this rotarydrilled well contained much sediment coarse enough for well construction. At well A 3, on the other hand, 9 closely spaced wells were drilled to depths of 75 feet and left with open-end casings, and of these, 3 were abandoned. The remaining 6 reportedly will yield 110 gpm together, but they are pumped at a rate of $55 \mathrm{gpm}$, or an average of only $9 \mathrm{gpm}$ per well, in order to prevent sand from being drawn in. Well $\mathrm{F} 75$, which is a drive point set in a 6 -inch drilled hole and packed with fine gravel, is finished in fine to very fine sand; its reliability is not known. Several successful test wells were drilled 
just west of Hyde Road near the Plainville town line, but thev are believed to tap ice-contact deposits that are continuous with those exposed just west of Scott Swamp Brook and are overlapped by the valley-train deposits.

North of Granby center, the only drilled well that taps valley-train deposits is in the valley of Hungary Brook near Notch Road. The narrowness of the valley fill in this area and the above-average slope of the terrace surface suggest that there were relatively rapid currents during deposition of the valley fill. That inference plus the existence of well $\mathrm{Gr} 90$, which is screened from 63 to 66 feet, suggests that the valley-train deposits are a favorable source of ground-water supply along Hungary Brook valley south of Quarry Road. The area north of Quarry Road, however, is unproved and must be regarded as questionable.

In summary, the valley-train deposits are not, in general, a favorable water-yielding unit. There are, however, means by which water can be obtained from these deposits in some places. These include:

1. Use of shallow wells. Although the saturated thickness of the coarse-grained upper unit is commonly small, driven or shallow drilled wells may tap it-or perhaps tap relatively coarse layers in the upper part of the lower unit. Also, because the valley-train deposits occur in lowlands, the water table is shallow, and dug wells can be constructed successfully almost everywhere. Special care should be taken that shallow wells be at safe distances from possible sources of contamination.

2. Skillful construction of screened wells. By skillful well construction, including use of the proper size screen and perhaps an envelope of coarse sand, a moderate yield occasionally can be obtained from well-sorted fine sand beds. Very fine sand and silt are unsatisfactory.

3. Testing to locate deep channel deposits. Coarse fluvial channel deposits are locally present at depth within the valley-train deposits, principally south of Avon center, and perhaps also northeast of Quarry Road in Suffield. Basal gravels are present below the valley-train sequence in a few places. Such deposits might be located by test drilling, although favorable aquifers would certainly be easier to find in areas underlain by ice-contact deposits.

4. Drilling near tributaries. The valley-train deposits may be a little coarser than average where major tributary streams enter the area of valley-train deposits from areas of ice-contact deposits, as such streams presumably brought in some coarse material while the valley-train deposits were being laid down. Nod Brook in Avon 
or Hop Brook in Simsbury are examples of such streams. Similarly, deposits along Hungary Brook southwest of Quarry Road in Granby may be generally coarse grained.

5. Drilling where the valley-train deposits overlap ice-contact deposits. The valley-train deposits are believed to overlap the ice-contact deposits where the two units come in contact. Accordingly, a well drilled near such a contact might penetrate through the valley-train deposits into older and typically coarser ice-contact deposits below. Many wells appear to be finished in this manner. Conditions are less favorable where the margin of the ice-contact deposits forms a high, regular bluff than where the bluff is low and irregular, because the high bluffs may contain fine-grained glaciolacustrine deposits, and also the zone of overlap by valley-train deposits may be narrow. Along the east. side of the lowland, red ice-contact deposits may occur buried below the valley-train sequence in a few localities where no such deposits are exposed along the sides of the lowland.

\section{ALLUVIAL DEPOSITS}

Although the -streams in the Farmington-Granby area have been cutting downward and laterally since the final departure of the ice, they have laid down .thin accumulations of sediment (referred to as alluvial deposits) almost everywhere along their courses. In some areas these alluvial deposits can be significant sources of water to wells.

\section{AREAL DISTRIBUTION AND THICKNESS}

Virtually all the perennial streams have spread mantles of detritus over flood plains along their courses, and small pockets of sand or gravel are scattered along the channels of even the smallest intermittent brooks. Along most streams, these deposits are only a few inches to a few feet thick and are unimportant as aquifers, so they have not been .mapped and are not discussed in this report. However, along the Farmington and Pequabuck Rivers and.Salmon Brook, and along some of their principal tributaries, alluvial deposits are somewhat thicker and were mapped. Only in the western upland are some sections of these major streams cut in till and bedrock, with little or no accumulation of alluvial deposits. The exact thickness of the alluvial deposits is difficult to estimate from driller's logs, but the writer interprets available logs as suggesting a thickness of 10 to 30 feet along the Farmington River and roughly 10 feet along Salmon Brook.

As the alluvial deposits are the most recent sediments mapped in the Farmington-Granby area, they overlie or overlap all other units with which they come in contact. 


\section{LITHOLOGY}

The alluvial deposits range in grain size from cobble and boulder gravel to silt. Average grain size differs widely from one part of the Farmington-Granby area to another, according to the grain size of the deposits being eroded and the velocity and transporting power of the stream. The alluvial deposits are composed predominantly of crystalline detritus because the major streams head in the western upland where only crystalline materials are available for erosion, and most of the stratified glacial deposits through which they flow were derived largely from crystalline rocks.

The flood-plain deposits being laid down at present along the Farmington River between Farmington center and Tariffiville consist largely of fine sand to silt, though medium to coarse sand and rarely gravel are also present. These deposits can be observed in the river banks at many points, in cuts in the natural levees along the river, and in auger holes bored in the flood plain. They are commonly rich in organic material; surface exposures vary from medium brown to deep chocolate, and logs of borings report fine brown organic-rich sediments near the surface (F 120, EG 27 , Si 129, table 15). In some places buried logs and nuts are reported at greater depths (Si 128 and 129, table 15). Deposits are believed to be similar along Salmon Brook south of Granbrook Park, and along the Pequabuck Rirer between Farmington center and the Farmington-Plainville line. Underlying the flood-plain deposits are from 5 to 20 feet of coarser channel deposits; they include pebbly coarse sand near Farmington center and in southern Avon but apparently are finer farther north.

Alluvial deposits become increasingly coarse upstream along the Farmington River and Salmon Brook. At several points on the broad flat west of Farmington center, auger holes or excavations penetrated pebble gravel immediately below the surface. The gravel appears to be only a few feet thick and overlies medium or coarse sand. In September 1955, after the disastrous August flood of that year, a large bar in the Farmington River channel farther upstream near River Glen was observed to consist largely of cobbles and boulders as much as 1 foot in diameter, and subordinate hard-packer sand. Sand and coarse gravel containing 5- to 6 -foot boulders were exposed in a roadcut north of Unionville near the point where Hawley Brook enters the Farmington River, and the driller's log of nearby well A 107 refers to "very coarse gravel with some silt, clay, and sand." Coarse sand and gravel are readily observable also in the flood plains of the East and West Branches of Salmon Brook north and south of Granby center. Farther upstream, in North Granby, the entire flat between Dismal Brook and East Branch Salmon Brook south of 
East Street is mantled with coarse gravel, and flood channels carved in the broad flood plain: just north of the junction of Belden Brook with East Branch Salmon Brook revealed uniformly coarse cobble gravel to a depth of 2 to 4 feet.

In general, field observation suggests that the average grain size of these upstream alluvial deposits is probably larger than that of nearby ice-contact deposits, but that the individual beds in the alluvium are more tightly packed and less well sorted.

WATER-YIELDING PROPERTIES

The alluvial deposits are of small importance as water-bearing material in the Farmington-Granby area, primarily because of their thinness and the presence of other more favorable water-yielding units.

In the lowland area along the Pequabuck River, the Farmington River between Farmington center and Tariffville, and Salmon. Brook south of about Granbrook Park, the alluvial deposits could support dug wells of low to moderate capacity. Such wells would be susceptible to contamination by the flood waters which inundate the area almost every year. The organic material present in these deposits might also influence water quality. Thus, the alluvium of the area is a rather poor source of water supply.

Upstream from this lowland area, along the Farmington River west of Farmington center and aıong Salmon Brook north of about Granbrook Park, the much larger grain size of the alluvium, combined with the shallow depth of the water table, make the alluvial deposits a favorable water-yielding unit despite their thinness. All 6 of the wells for which records are available that tap alluvial deposits are located in these upstream sections, and all but 1 well are very successful.

Two of the six records are of drilled test wells. Well F $98 \mathrm{c}$ is 31 feet deep and had a drawdown of $41 / 2$ feet when pumped at $110 \mathrm{gpm}$, indicating a specific capacity of $24 \mathrm{gpm}$ per ft. At well A 107, 3 test wells, drilled close together, encountered bedrock at 10, 17, and 21 feet. Although no information is available on the yield or drawdown of the three test wells, the driller notes that the formation was water bearing but not favorable for well construction primarily because of lack of depth. However, he notes that the formation was suitable for development of a collection gallery if recharge from nearby Hawley Brook were sufficient.

The other 4 wells that tap alluvium are dug wells; 3 of these are along the Farmington River flood plain. Well F 5, about 12 feet deep, reportedly had a drawdown of 4 feet when pumped at $60 \mathrm{gpm}$, 
indicating a specific capacity of $15 \mathrm{gpm}$ per ft; nearby well $\mathrm{F} 94$ was reportedly pumped at 60 to $100 \mathrm{gpm}$. Well $\mathrm{A} 22$ is reported to have developed no drawdown after 50 hours of pumping. Little information is available on the yield and reliability of the fourth well, Gr $105 \mathrm{a}$, but it yielded enough water for a small restaurant except at times in summer.

Much of the alluvium along Salmon Brook from the crystalline upland to Granby center, and along the Farmington River from the upland to about a quarter of a mile east of the south end of Brickyard Road, is underlain by relatively conrse-grained stratified glacial drift that is generally favorable for well construction. Accordingly, even though the alluvium is also favorable it seldom is utilized as a source of water in these areas. (Well F 98c was completed in allnvium, but only after an attempt to complete it in stratified drift failed.) Howerer, few ice-contact deposits are present below the water table along the reaches of these streams within the western upland. Accordingly, within the upland, the alluvium, despite its very limited thickness and extent, has the best potential of any geologic unit as a source of water to high-capacity wells.

\section{GROUND-W ATER AVAILABILITY IN THE STRATIFIED DRIFT AND ALLUVIAL DEPOSITS}

Because the stratified glacial deposits and the alluvial deposits are the most important potential aquifers and because their lithology and water-yielding potential differ markedly from one locality to another within the Farmington-Granby area, the writer's interpretation of the possibilities for development of ground-water supplies at any point within the area of these deposits is summarized in plate 3. No similar map is provided for the glacial till, because it is much less important as an aquifer, nor for the various bedrock units, because with few exceptions the average water-yielding capacity of each of these units appears to be about the same throughout its areal extent.

Most water supplies in the Farmington-Granby area are obtained from wells, and plate 3 is concerned primarily with possibilities for well construction. Differences in depth to water and in chemical quality of ground water in different localities are discussed in later sections of the text.

The thickness of the unconsolidated deposits at many points can be estimated by subtracting the altitude of the bedrock surface, shown on plate 1, from land surface altitude, which is shown on U.S. Geological Survey topographic maps. 


\section{GROUND WATER}

\section{OCCURRENCE}

Most earth materials are not solid but contain numerous openings or voids. Below a certain depth all these voids are filled with water under hydrostatic pressure, and the materials are saturated. Water within this zone of saturation is termed ground water, and the upper surface of the zone of saturation is known as the water table. Water will stand at the level of the water table in a well that penetrates the zone of saturation. Earth materials above this zone are said to be in the zone of aeration. Water fills some openings of capillary and subcapillary size in this zone, particularly those a few feet or less above the water table, but the water is held in them by molecular attraction and not by hydrostatic pressure.

The water table is generally a sloping surface, being higher in areas of recharge, where water is added to the ground-water body, than at points or areas of discharge. In the Farmington-Granby area, the water table slopes from hills and terraces to the valley bottoms, reflecting the fact that streams are the major avenues of ground-water discharge in this region. The water table has somewhat less relief than the land surface, however, as it tends to be nearer the surface in valley bottoms than in hills and terraces. It actually intersects the land surface in lakes and perennial streams. Accordingly, the form of the water table is essentially that of a subdued replica of the land surface.

Even though the water table conforms generally to the land surface, its slope is influenced by the thickness and permeability of the waterbearing material, and by the amount of water moving through that material. Infiltrating rainfall builds up the water table in a hill until its gradient is sufficiently steep that ground water will flow into nearby valleys at a rate equal to the infiltration. In materials of low permeability, such lateral movement is slow; so gradients generally are nearly as steep as the land surface. The smaller resistance to groundwater flow in permeable materials results in relatively small gradients. Consequently, the water table occurs at a higher altitude within a hill of relatively impermeable till than it does in a hill of similar size and altitude formed of permeable stratified drift. Where a terrace underlain by permeable medium and coarse sand adjoins a flat valley bottom, the water table normally slopes so gently beneath the terrace that it stands at only a slightly higher altitude than beneath the valley flat. (See cross section $\mathrm{A}-\mathrm{A}^{\prime}$, plate 2.) Under natural conditions the slope of the water table is greatest during the period of maximum recharge, when the amount of water being transmitted is at a maximum. 
An example of the effect of topography and lithology on the depth to the water table in glacial drift in the Farmington-Granby area is given in the following table, in which data from 4 dug wells, all located within 5 miles of each other, are compared. These data illustrate that the water table is shallower in till on a hilltop than beneath permeable sand terraces, and that it is nearest the surface in a valley flat.

Relation of water levels to topography and lithology

\begin{tabular}{|c|c|c|c|c|}
\hline $\begin{array}{l}\text { Well } \\
\text { No. }\end{array}$ & Topographic situation & Water-yielding material & $\begin{array}{l}\text { Depth to } \\
\text { water (feet } \\
\text { below land } \\
\text { surface) }\end{array}$ & Date \\
\hline $\begin{array}{l}\text { Su } 48 \mathrm{a}_{\ldots} \ldots \\
\text { Su } 48 \ldots \ldots \\
\text { Gr } 20 \ldots \ldots \\
\text { EG } 32 \ldots \ldots\end{array}$ & $\begin{array}{l}\text { Valley flat._. } \\
\text { Edge of terrace }\end{array}$ & $\begin{array}{l}\text { Stratified drift } \\
\text { Drumlin deposits } \\
\text { (till). }\end{array}$ & $\begin{array}{r}3.08 \\
24.60 \\
22.68 \\
7.78 \\
10.79\end{array}$ & $\begin{array}{l}11-12-55 \\
11-12-55 \\
11-25-55 \\
11-10-55 \\
12-9-55\end{array}$ \\
\hline
\end{tabular}

Although the water table is normally deepest beneath the highest part of any given hill, in some places the water level in a well near the base of a slope is as deep as or deeper than the level in a well near the top. Such anomalies can result from variations in permeability of the materials within the hill, as the water table will slope more gently and hence be deeper in the relatively permeable materials. In the Farmington-Granby area, this type of anomaly is more common in ground-moraine or drumlin deposits, because of their highly variable lithology, than in stratified glacial drift. Brown (1928, p. 26-27), discussed this matter, and examples can be seen on maps in U.S. Geological Survey Water-Supply Papers 466 and 470 (Palmer, 1921, 1920).

Water levels in bedrock wells bear a relation to topography that is similar to the relation in unconsolidated deposits, although the pattern is complicated by differences in permeability that result from the irregular distribution and interconnection of the fractures in which the water occurs and by the varied thickness of the glacial-drift mantle. Water levels are deeper than average in most wells near the crest of Talcott Mountain. (See well F 7, fig. 14.) Well F 102, drilled on a high peak at an altitude of about 705 feet, reportedly has a static water level of 225 feet. No wells have been drilled near the crest of other steep mountains in the Farmington-Granby area, such as Manitook Mountain in Granby or the bluff west of State Route 177 near well A 80 in Avon, but water levels in the bedrock are presumably deep at such locations also. Water levels in bedrock wells on broad, gentle hills, such as the hill southwest of Weatogue, Bushy Hill 
in Granby, or several hills within the western upland in Granby and Simsbury, are not especially deep.

Water levels in bedrock wells stand at higher altitudes in bedrock hills than in lower areas nearby. Beneath drumlins in the Farmington-Granby area, however, water levels in rock wells stand at about the same altitude as they do in nearby areas where the drift is thinner, so that the depth to water in rock wells increases on a drumlin by about as much as the glacial drift increases in thickness.

In areas where materials of relatively uniform permeability extend downward from the surface into the zone of saturation, the ground water is unconfined, and its surface is free to rise and fall, so that it is said to be under water-table conditions. Water-table conditions occur throughout much of the glacial drift and parts of the bedrock in the Farmington-Granby area. On the other hand, where ground water fills a permeable layer underlying a relatively impermeable unit, the upper surface of the ground-water body is not free to rise and fall, although the hydraulic head on it may vary; such water is said to be confined or under artesian conditions. Confining layers in the area covered by this investigation may consist of till, silt, or clay, or a zone of only slightly fractured bedrock. Where a well penetrates such an impermeable layer and finds water under artesian conditions below, the water will rise in the casing to a level proportional to the hydrostatic pressure at the well screen or bottom of the well. Flowing wells, in which the water rises above the land surface, are uncommon in the Farmington-Granby area. Most bedrock wells tap water under some artesian pressure, however, and the water rises above the bedrock surface in many rock wells drilled through thick glacial drift in bedrock valleys. A few wells finished in glacial drift obtain water under artesian conditions-for example, A 24 (table 16) and EG 36a (fig. 11).

Several of the typical relations discussed above are illustrated in figure 11, which is a cross section drawn through wells EG 33 and EG 36 in East Granby. The relative elevation of the measuring point of each well shown in this figure was determined by spirit leveling; water levels were measured on August 18, 1956. Distances were scaled from the topographic map, and well depths and depths to rock were reported by drillers and owners. The water table is defined at the northeast end of the section by the water level in dug well EG 32 and the water level in the brook and the swampy area around it. The water in the bedrock rises above the rock surface in wells at the southwest end of the section, indicating that the water occurs under artesian conditions. The artesian water level, or piezometric surface, is distinct from-and in this case generally lower than-the water table. The piezometric surface is as much as 70 feet below land surface be- 


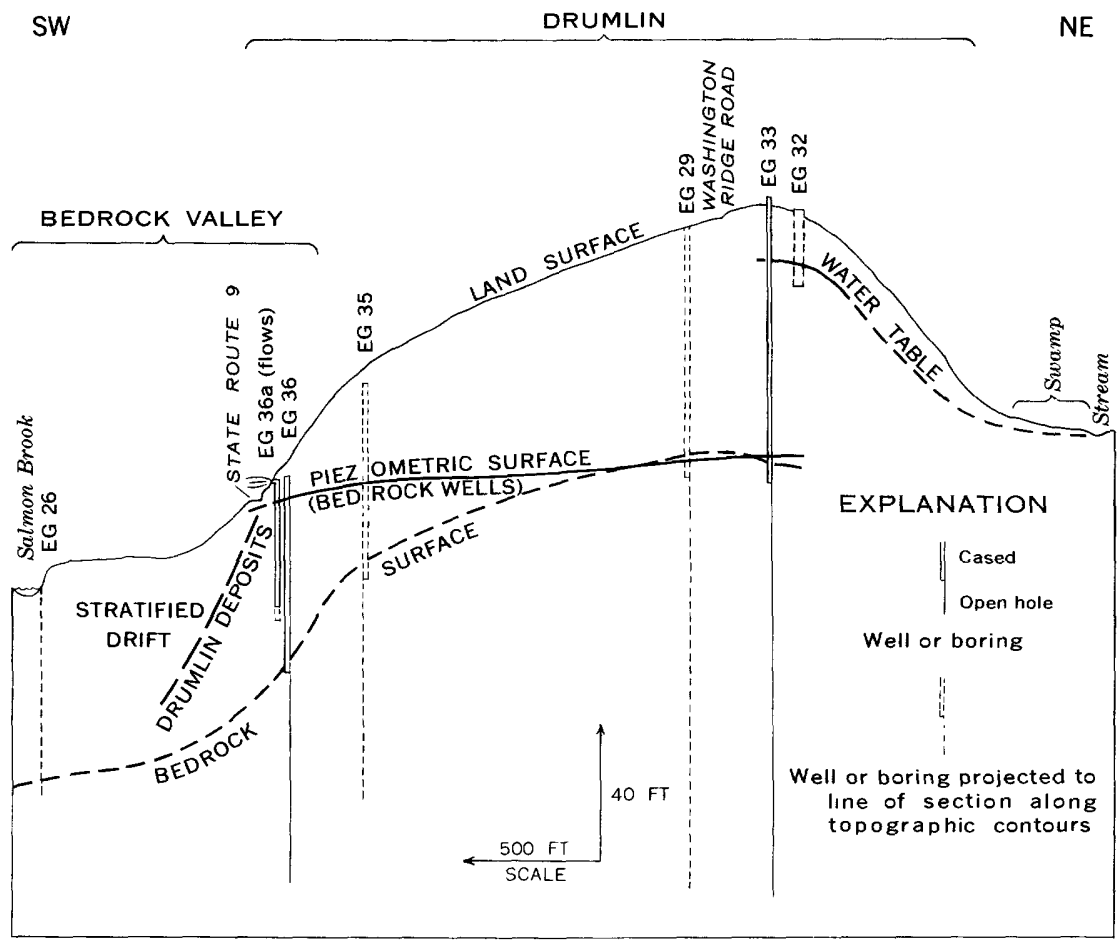

Figure 11.-Cross section through wells EG 33 and 36, showing water levels and topography in a part of East Granby.

neath the drumlin, which is unusually deep for water levels in the Farmington-Granby area. Where the surface of the bedrock slopes toward a bedrock valley, the piezometric surface is considerably above the top of the rock.

One unusual phenomenon shown in figure 11 is that well EG 36a obtains water under considerable artesian pressure from the glacial drift. This well probably taps a sandy, permeable zone in the drumlin deposits that extends farther upslope. As this well flows, the piezometric surface of the water must be higher than that of the water in the underlying bedrock.

\section{RECHARGE AND DISCHARGE}

\section{RECHARGE}

Nearly all the ground water in the Farmington-Granby area is derived from local precipitation. Relatively small quantities enter the area in some places by underground flow from adjacent areas, and still smaller quantities infiltrate from waste-water disposal systems. 
The amount of precipitation on the area is the fundamental factor determining the amount of water available. From,precipitation records at four weather stations, two just west of the Farmington-Granby area and two just to the east, normal annual precipitation 'values of 40.57 to 47.28 inches have been computed. The average of 43.68 inches may be taken as the normal annual precipitation for the area. (See table 1.) Rainfall of 1 inch, or snow having a water content equivalent to 1 inch of rain, amounts to about 17 million gallons of water per square mile. Thus the normal annual precipitation of 43.68 inches is equivalent to about 760 million gallons of water per square mile annually, or 3.2 cfs (cubic feet per second) per square mile. Accordingly, the 141.6 square miles of the Farmington-Granby area receive from average precipitation, 107 billion gallons of water per year (460 cfs).

The largest part of the precipitation never reaches the zone of saturation. Part flows into rills and streams as surface runoff, part is directly evaporated, and part percolates into the soil. Of the water that enters the soil, part is retained in the root zone as soil moisture and later is evaporated or taken up by plants and transpired into the atmosphere. The remainder continues to seep downward and finally reaches the water table. Variations in the amount and rate of precipitation, infiltration capacity of the soil, permeability of earth materials, depth to the water table, topography, and vegetation-all affect the amount of ground-water recharge.

Some recharge to the ground water of the Farmington-Granby area takes place by lateral underground flow from adjacent areas. The quantity of ground water introduced in this manner is difficult to estimate but is believed to be much smaller than that resulting from infiltration of local precipitation. It is limited by the small extent of marginal areas in which the water table slopes toward the Farmington-Granby area and by the low permeability of the groundmoraine deposits and bedrock that occur in such areas. The west border of Simsbury and the entire east edge of the FarmingtonGranby area north of Farmington are very close to the crests of ridges, from which underground as well as surface drainage generally flows in opposite directions. The till-covered bedrock upland in the town of Burlington west of Unionville and Lake Garda, however, is probably the source of some lateral recharge to northwestern Farmington, and similarly some ground water probably flows. from Hartland and from Massachusetts across the western and northwestern boundaries of Granby.

According to the topographic maps of the Tariffville and Southwick quadrangles, the altitude of water in Congamond Lakes in Mas- 
sachusetts and associated swamps along the state line is considerably higher than that in lakes, swamps, and wells south of Notch Road west of Manitook Mountain in Granby. This relation suggests that significant quantities of ground water may be moving southward into Grarby through the permeable ice-contact deposits filling the bedrock valley in that area. Reported water levels in wells along Quarry Road west of Manitook Mountain, however, indicate that the altititude of the water table here is very close to, and in places possibly a little higher than, the altitude of the lakes and swamps in Massachusetts as shown on the topographic map of the Southwick quadrangle. Accordingly, the water table may slope gently north and south from the vicinity of the state line. Careful measurement of water levels would probably be required to determine the direction of the hydraulic gradient in this locality.

A small underground flow into the area may occur in stratified drift east of State Route 177 along the Avon-Canton line and next to the Pequabuck River along the Farmington-Plainville line. In each area the primary slope of the water table is probably from the valley walls toward the stream, but a minor component of slope presumably exists parallel to streamflow.

Small amounts of recharge result from infiltration of waste water introduced into the ground via the numerous domestic and industrial cesspools or septic tanks and other drainage systems in the area.

\section{DISCHARGE}

Once water reaches the zone of saturation, it begins to move in the direction of the hydraulic gradient to points or areas of discharge. Water is discharged from the zone of saturation wherever the water table intersects the land surface: in streams, lakes, and ponds, and in springs and seeps. Furthermore, ground water is evaporated where the water table is near the surface and is transpired into the atmosphere where the roots of plants extend to the water table or to the capillary fringe. Swamps and ground-water ponds, which are most common on river flood plains and in ice-block depressions, are areas of especially large evapotranspiration. Relatively small quantities of water leave the Farmington-Granby area by lateral underground flow. Also, discharge is produced artificially by pumping from wells and from ground-water ponds (ponds which are essentially surface outcrops of the water table, with no significant inflowing streams).

The largest part of the water discharged from the zone of saturation in the Farmington-Gramby area drains into local streams and lakes, principally by seepage through their banks and bottoms. Streamflow consists of the ground-water discharge plus surface runoff. Sur- 
face runoff is made up of water that reaches the streams by flowing over the land surface, precipitation falling into streams, and water stored temporarily in the channel banks when the channel is full. After a rain the surface runoff reaches the streams quickly, and it is nearly all discharged from the drainage basin within a few days. Ground-water discharge, on the other hand, continues over a prolonged period, and although the rate of discharge is greatest during the spring when the water table is high, a small but steady flow generally continues in the major streams even during periods in the summer and early autumn when there is no ground-water recharge and very little surface runoff. Streamflow derived from groundwater discharge is known as base flow.

Except for eastern Farmington, which is drained by tributaries of the Park River, the entire Farmington-Granby area is drained by the Farmington River. On the basis of records of discharge at several gaging stations on the Farmington River and its tributaries (published by the U.S. Geol. Survey in annual Water-Supply Papers entitled "Surface Water Supply of the United States, Part 1-A, North Atlantic Slope Basins Maine to Connecticut"), the Hartford, Conn., office of the Survey's Surface Water Branch estimated that the mean annual runoff from the Farmington-Granby area is about $1.80 \mathrm{cfs}$ per square mile, or about 420 million gallons per year per square mile. Thus the mean annual runoff from the 141.6-square-mile report area is about $255 \mathrm{cfs}$, or 60 billion gallons per year.

Streamflow records can be used to estimate the part of the mean annual runoff from the Farmington-Granby area that is groundwater discharge. The flow records for the Farmington River are difficult to use, because the flow of this stream is regulated by storage and releases from various flood-control, water-supply, and power reservoirs above the gaging stations. The drainage basin of Salmon Brook above the gage near Granbrook Park, however, contains no major reservoirs, is largely within the report area, and is considered to be fairly typical of the Farmington-Granby area as a whole in that it contains a tract of dissected till-covered upland and a tract of relatively flat lowland mantled with stratified drift. Accordingly, this basin was selected for study of the relation of base flow to total runoff. Hydrographs of daily discharge covering the period October 1946 through September 1955, based on records published annually by the Geological Survey, were supplied by the Connecticut office of the Survey's Surface Water Branch. They were compared with records of daily precipitation at West Hartland, Barkhamsted, Bloomfield, and Windsor Locks during this period. A depletion curve for 
Salmon Brook was prepared, and with the aid of the depletion curve a base-flow eurve was sketched in below two discharge hydrographs, one of a water year with relatively small total flow, 1949-50 (see fig. 12), and the other of a water year with relatively large total flow, 195253. The mean annual base flow was determined, from these base-flow curves, to be 51 percent of the mean annual flow in the relatively wet year and $60^{\circ}$ percent in the dry year; the average was taken as 55 percent. If this percentage is applied to the values for mean annual runoff from the Farmington-Granby area, the mean ground-water discharge per square mile is indicated to be about $1 \mathrm{cfs}$, or 230 million gallons per year; hence, over the entire Farmington-Granby area, the mean ground-water discharge is about $140 \mathrm{cfs}$, or 33 billion gallons per year.

The computations described above indicate that an average of 25 percent of the precipitation that falls in the Farmington-Granby area quickly enters the streams as surface or storm runoff, and about 31 percent reaches the zome of saturation and is released to the streams over a longer period of time as ground-water discharge. The remaining 44 percent must be accounted for by evapotranspiration. Because of the method of computation, however, this last percentage figure includes not only all water evaporated or transpired from the land surface and the zone of aeration but also water removed by evapotranspiration from the zone of saturation and part of the ground water withdrawn by man.

Meinzer and Stearns (1929, p. 142), in a detailed hydrologic study of the Pomperaug basin of Connecticut, an area of somewhat different geology, calculated that of the total precipitation on that basin, 27 percent became surface runoff, 191/2 percent became ground-water discharge, and 52 percent was disposed of by evapotranspiration. (The remaining $11 / 2$ percent was accounted for by a temporary increase in ground-water storage.) They further calculated that evapotranspiration of ground water amounted to 14 percent of the total precipitation.

The amount of ground water that is discharged from the Farmington-Granby area by lateral underground flow is probably small. About 2 square miles of permeable stratified drift in West Suffield drain to Congamónd Lakes in Massachusetts, which discharge northward. In the part of Farmington east of Talcott Mountain, the land slope and surface drainage is eastward, and there is probably some eastward movement of ground water through the ground-moraine deposit and bedrock. No other significant areas of lateral underground discharge are known. 


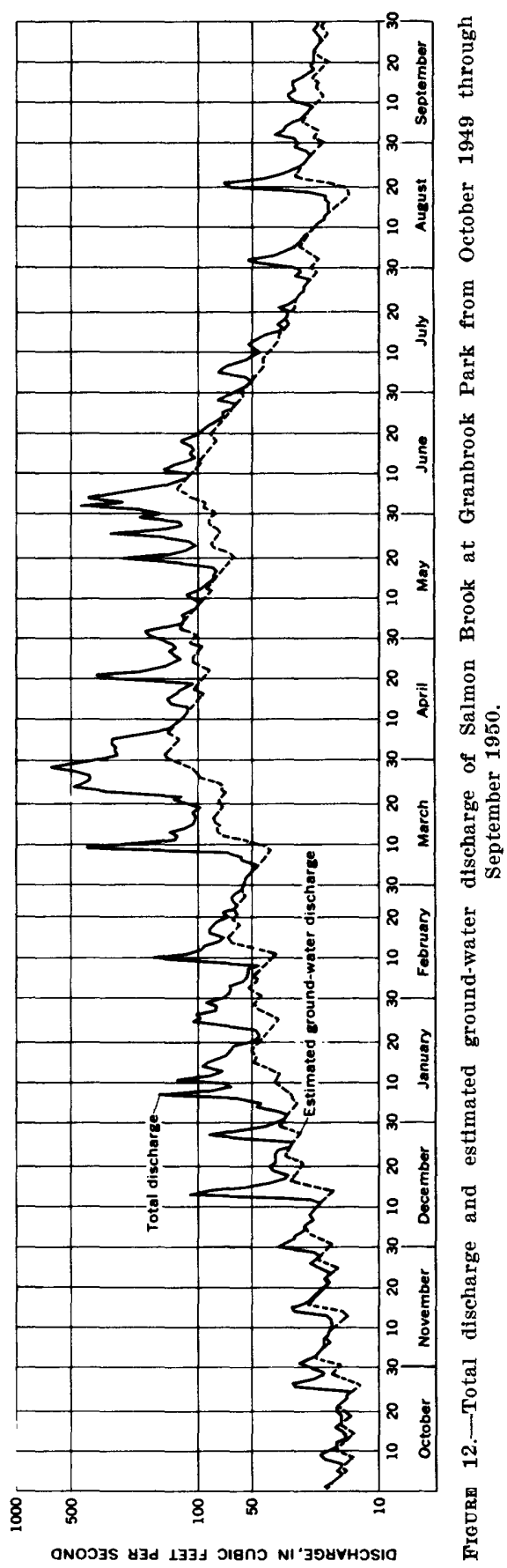


Water is artificially discharged from the zone of saturation through pumping from wells and ground-water ponds. Total withdrawal of ground water by man within the Farmington-Granby area was probably about 900 million gallons per year in 1957 . The data on which this estimate is based are discussed below under "Use of ground water." Some of the water used by man eventually returns to the zone of saturation after being released into the ground, some flows into streams, and the remainder is exaporated or transpired into the atmosphere.

\section{USE OF GROUND WATER}

Estimates of the quantities of ground water withdrawn by various categories of users in the Farmington-Granby area are summarized in tables 7-9, and the estimated use in each town is given in table 10 . These estimates indicate a total artificial discharge of ground water in the Farmington-Granby area of about 900 million gallons per year.

The amount of ground water pumped in 1957 by public water systems, 151 million gallons, was considerably less than the 237 million gallons estimated to have been used during the same year in homes supplied by individual wells. 'However, three public systems - the Farmington Water Co., the Unionville Water Co., and the Village Water Co. of Simsbury-also distributed in 1957 about 317 million gallons of surface water.

Most of the major industrial water users supplied by individual wells were located in Farmington. The principal use of water was for air conditioning, although some process water was also pumped. A rough estimate of the pumpage by self-supplied small commercial establishments not visited during this investigation, such as gasoline stations and shops, is included in the pumpage shown for industrial and commercial users in table 9.

The very heavy water use recorded for wash-plant operations at sand and gravel pits is deceptive in a sense. Large pumps run continuously during the working day for at least 9 months of the year; but as soon as the water has washed the sand or gravel and carried the fines away it is allowed to seep into the ground, in most cases not far from the ground-water ponds from which it was withdrawn. Hence, this use is essentially nonconsumptive, except for some evaporation loss during the operation. All wash plants in the report area were in Farmington.

Large quantities of ground water were used for agricultural purposes by the Avon Country Club, which watered its golf course from well A 19a, and by Cullman Bros., Inc., which irrigated tobacco from well Si 84 and from an excavated ground-water pond along Firetown Road in Simsbury. Total pumpage by these concerns was estimated 
from data on duration and rate of pump operation at about 105 million gallons per year. Cullman Bros., Inc., also pumped considerable quantities of water from surface streams for irrigation purposes. The American Sumatra Tobacco Co. in southern Granby and East Granby, and tobacco companies in Suffield other than Cullman Bros., also pumped some ground water for irrigation, and relatively small quantities were used by livestock and by minor farm operations throughout the Farmington-Granby area; an order-of-magnitude estimate of the ground water pumped for these purposes is included in the pumpage shown for agricultural users in table 9 in order that a rough approximation of total ground-water use within the Farmington-Granby area could be made.

\section{TABLE 7.-Estimated use of ground water for public water-supply systems during 1957}

[PUC, Public Utilities Commission 47th Ann. Rept.]

\begin{tabular}{|c|c|c|c|c|c|}
\hline \multirow[b]{2}{*}{ Name } & \multirow[b]{2}{*}{ Source of data } & \multicolumn{2}{|c|}{ Service } & \multicolumn{2}{|c|}{$\begin{array}{l}\text { Ground-water } \\
\text { pumpage }\end{array}$} \\
\hline & & Town & $\begin{array}{l}\text { Number } \\
\text { of persons } \\
\text { served }\end{array}$ & $\begin{array}{c}\text { Yearly } \\
\text { pumpage } \\
\text { (millions } \\
\text { of gallons) }\end{array}$ & $\begin{array}{l}\text { A verage } \\
\text { daily } \\
\text { pumpage } \\
\text { (thou- } \\
\text { sands } \\
\text { of gallons) }\end{array}$ \\
\hline $\begin{array}{c}\text { Farmington Water } \\
\text { Co. }\end{array}$ & PUC & $\begin{array}{l}\text { Farm- } \\
\text { ington. }\end{array}$ & 2,000 & & \\
\hline $\begin{array}{c}\text { Unionville Water } \mathrm{Co} \\
\text { Do }\end{array}$ & $\begin{array}{l}\text { PUC and com- } \\
\text { pany officials. }\end{array}$ & Avon & $\begin{array}{r}2,844 \\
340\end{array}$ & & \\
\hline $\begin{array}{l}\text { East Farmington } \\
\text { Water-Supply }\end{array}$ & $\begin{array}{l}\text { State Dept. of } \\
\text { Health. }\end{array}$ & $\begin{array}{l}\text { Farm- } \\
\text { ington. }\end{array}$ & 150 & 12.7 & 17.5 \\
\hline $\begin{array}{c}\text { Maple Ridge Farms } \\
\text { Water Association. }\end{array}$ & -do & ... do & 110 & 12.0 & ${ }^{1} 5.5$ \\
\hline Avon Water Co & $\mathrm{PUC}_{\ldots} \ldots$ & Avon_. & 1,150 & 26. 9 & 73. 7 \\
\hline $\begin{array}{l}\text { Avon Old Farms } \\
\text { School. }\end{array}$ & School officials & $\ldots$ do & 245 & 19. 6 & 53.8 \\
\hline $\begin{array}{l}\text { Village Water Co. } \\
\text { of Simsbury. }\end{array}$ & $\begin{array}{l}\text { PUC and com- } \\
\text { pany officials. }\end{array}$ & $\begin{array}{l}\text { Sims- } \\
\text { bury. }\end{array}$ & & ${ }^{3} 45.2$ & 124. 1 \\
\hline $\begin{array}{l}\text { Westover Plain } \\
\text { Water Co. }\end{array}$ & PUC & _. do do... & 270 & 47.4 & 420.2 \\
\hline $\begin{array}{l}\text { Tariffville Fire } \\
\text { District. }\end{array}$ & $\ldots$ do & $\ldots$. do & 1,475 & 440.3 & ${ }^{4} 111$. \\
\hline $\begin{array}{l}\text { Cullman Bros. Farm } \\
\# 1 \text {. }\end{array}$ & $\begin{array}{l}\text { Farm superin- } \\
\text { tendent. }\end{array}$ & $\ldots$. do $\ldots$ & 5175 & 1. 4 & \\
\hline $\begin{array}{l}\text { Salmon Brook } \\
\text { District }\end{array}$ & PUC & Granby - - & 475 & 6. 5 & 17. 8 \\
\hline Total & & & & 151. 0 & 414. 6 \\
\hline
\end{tabular}

1 Estimated at 50 gpd per capita.

2 Number of permanent residents; system also supplies boarding students, is used for lawn watering and other purposes.

${ }^{3} 67.4$ million gallons of surface water also distributed in 1957 .

4 Estimated at 75 gpd per capita to allow for nonhome users.

${ }^{5}$ Number of persons at boarding house, used only 6 weeks in summer. 
TABLE 8.-Estimated use of ground water for private domestic water supplirs during 19.jy

\begin{tabular}{|c|c|c|c|}
\hline \multirow{2}{*}{ Town } & \multirow{2}{*}{$\begin{array}{c}\text { Estimated } \\
\text { number of } \\
\text { persons served } \\
\text { by individual } \\
\text { wells }\end{array}$} & \multicolumn{2}{|c|}{$\begin{array}{c}\text { Ground-water pumpage } \\
\text { (Estimated, at } 50 \text { gpd per capita) }\end{array}$} \\
\hline & & $\begin{array}{c}\text { Yearly } \\
\text { (millions } \\
\text { of gallons) }\end{array}$ & $\begin{array}{l}\text { A verage } \\
\text { daily } \\
\text { (thousands } \\
\text { of gallons) }\end{array}$ \\
\hline Farmington $\ldots . . . . .$. & 13,696 & 67.3 & 184.8 \\
\hline Avon $\ldots \ldots \ldots$ & 12,765 & 50.4 & 138. 2 \\
\hline Simsbury $_{\ldots} \ldots \ldots \ldots$ & 11,035 & 18. 8 & 51.8 \\
\hline Granby & ${ }^{1} 3,125$ & 56.9 & 156. 2 \\
\hline East Granby ${ }^{2}$ & 3734 & 13. 4 & 36.7 \\
\hline Suffield ${ }^{2} \ldots \ldots \ldots \ldots$ & ${ }^{3} 1,650$ & 30.1 & 82.5 \\
\hline Total_ & & 236. 9 & 650. 2 \\
\hline
\end{tabular}

1 Obtained by subtracting number of persons in town served by public systems (table 7) from 1957 population estimate for town (Connecticut State Dept. of Iealth, 1957).

2 Part within report area.

3 All persons within report area (from table 4) are served by individual wells.

TABLE 9.-Estimated total use of ground water in 1957 in the Farmington-Granby area, by categories of use

\begin{tabular}{|c|c|c|}
\hline \multirow{2}{*}{ Category of use } & \multicolumn{2}{|c|}{ Ground-water pumpage } \\
\hline & $\begin{array}{c}\text { Yearly pumpage } \\
\text { (millions of } \\
\text { gallons) }\end{array}$ & $\begin{array}{l}\text { Average daily } \\
\text { pumpage (thou- } \\
\text { sands of gallons) }\end{array}$ \\
\hline Public water supplies ... & 151 & 415 \\
\hline Private domestic water supplies & 237 & 650 \\
\hline Industrial and commercial users $\ldots$ & 62 & 170 \\
\hline Wash plants at sand and gravel pits & 280 & 770 \\
\hline Agricultural users & $170(?)$ & $467(?)$ \\
\hline Total (rounded) & 900 & 2,500 \\
\hline
\end{tabular}

TABLE 10.-Estimated total ground-water use in 1957 in the Farmington-Granby area, by towns

Farmington:

Gravel-pit use

All other uses .

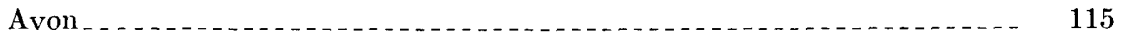

Simsbury

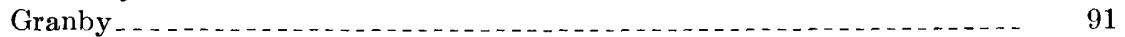

East Granby $1 \ldots$

Suffield $1 \ldots \ldots \ldots \ldots \ldots \ldots \ldots \ldots$

Total $\ldots \ldots 0$

1 Part within report area. 
The daily use of water varies considerably from one season of the year to another. The demand is at its peak in midsummer. In winter, by contrast, little water is pumped for agricultural purposes or for air conditioning, gravel pits cannot use water when the air temperature is below $32^{\circ} \mathrm{F}$, and domestic consumption of water is reduced. Accordingly, the ground-water pumpage on a given day may be far above or below the average daily use.

\section{WATER-LEVEL FLUCTUATIONS}

The water level in a well does not remain stationary but fluctuates like the water level in a surface reservoir. Natural factors, such as changes in the rate of evapotranspiration, changes in atmospheric pressure, and variations in recharge cause many fluctuations; others occur in response to pumping and other activities of man. Periodic measurement of the water levels in selected wells in an area provides knowledge of the pattern and amplitude of water-level fluctuations in the different aquifers under varying natural and man-made conditions. Such knowledge is useful in determining the causes and timing of recharge and discharge and estimating the changes in storage in the ground-water reservoir.

Periodic water-level measurements were made in 16 wells in the Farmington-Granby area as part of this investigation. In 12 of these wells measurement was continued for a considerable period of time, which in most of them included the summers of 1953 and 1954 and the period from September 1955 through December 1958. Complete records of these 12 wells are given in table 11 . Their locations are shown on plate 1 , and the measurements obtained from them appear as hydrographs in figures 13 and 14 . Automatic waterlevel recorders were operated for various lengths of time on three wells, as indicated in figure 14; otherwise, the hydrographs show measurements made by steel tape, usually at monthly intervals. Dashed lines are used where the interval between measurements exceeded one month. Monthly precipitation for the area is also shown in figures 13 and 14; it was obtained by averaging the precipitation at four nearby stations, Barkhamsted, Collinsville, Hartford Weather Bureau (Bradley Field), and Hartford Brainard Field. 


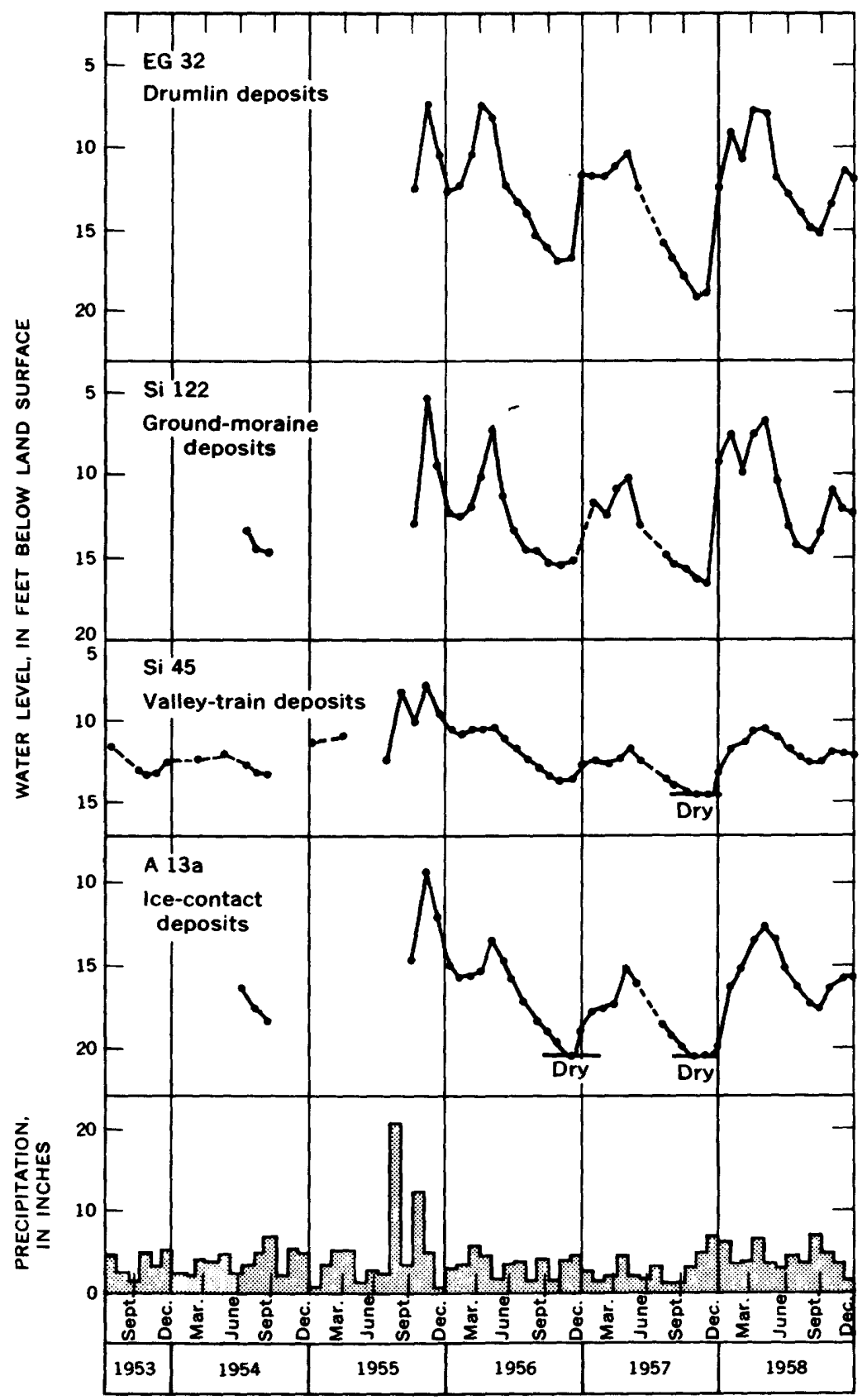

FigURe 13.-Water-level fluctuations in four observation wells flnished in unconsolidated deposits. 

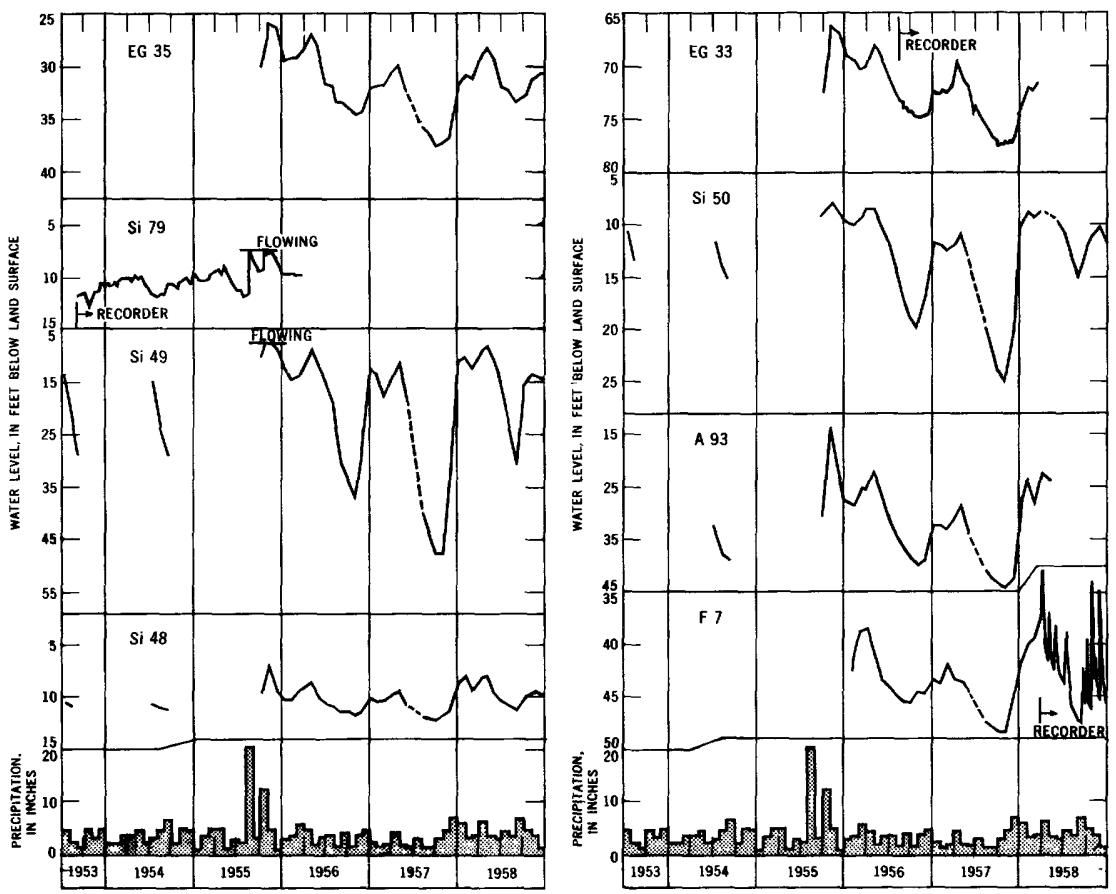

Figdre 14.-Water-level fuctuations in eight observation wells flnished in the Newark group.

\section{NATURAL FLUCTUATTONS}

\section{SEASONAL FLUCTUATIONS}

Seasonal changes in the rate of evapotranspiration are the most important cause of water-level fluctuations in wells within the Farmington-Granby area. This relation is illustrated by the water-level hydrographs of several observation wells (figs. 13 and 14). The hydrographs indicate that in 1956,1957 , and 1958 water levels showed a net rise during the early part of the year to reach yearly highs near the end of April in most wells. The rise was followed by a steady decline, which continued in 1956 until about the end of October; in 1957 the decline continued until October or November, depending on the well; and in 1958 it continued until about the end of August. A similar pattern of water-level fluctuation-high in March, April, or May and low in October or November-is characteristic of most wells in Connecticut. The period of decline coincides with the growing season and with the warm part of the year, when evaporation and transpiration of ground water are at a maximum, and when most of the water that penetrates into the ground replaces previously depleted soil moisture so that little ground-water recharge takes place. A net rise of the 


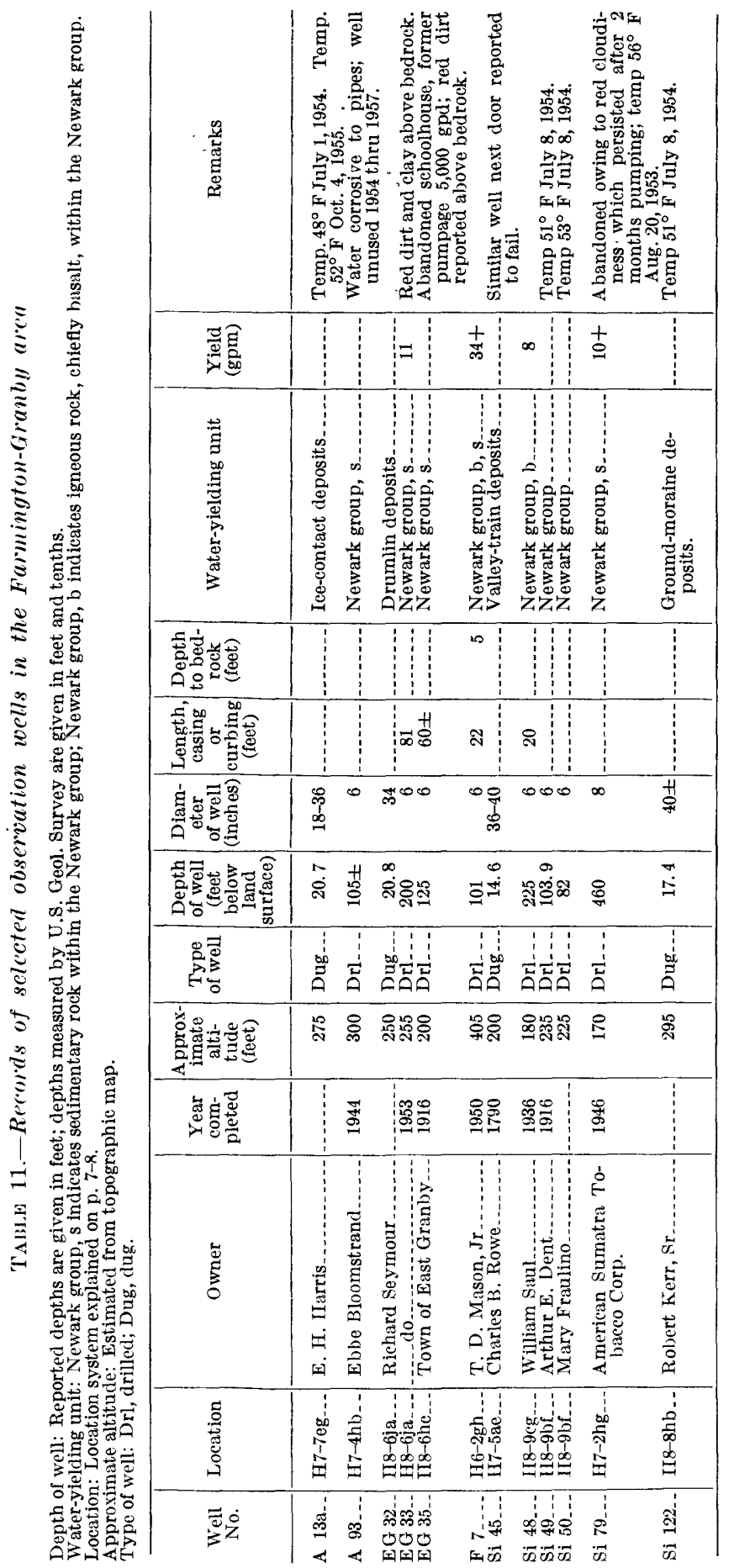


water table generally occurs during the winter and early spring, when evaporation and transpiration are at a minimum, even though the normal monthly precipitation during this period is no greater than during the warmer part of the year. (See table 1.)

Although seasonal changes in the evapotranspiration rate are the principal cause of annual water-level fluctuations, the amount of rainfall also influences the amount of fluctuation. For example, during the unusually dry summer of 1957 , water levels declined to unusually low levels; during the following summer, when rainfall was much greater, the decline was much less and ended earlier than usual. Furthermore, unusual rainfall distribution can cause irregularities in the pattern of fluctuation; for example, an abnormally rainy period during the summer months can cause ground-water recharge and, thus, a contraseasonal rise in the water table. This is illustrated best by the rise in water level to, or nearly to, record high levels at virtually every observation well in Connecticut following the unprecedented heavy rains that accompanied the hurricanes of August and October 1955 .

Continuous records of water-level fluctuations obtained by automatic recorders in wells $\mathbf{F} 7$ and Si 79, both tapping the Newark group, show that water levels in these two wells rise promptly during heavy rains. The water level in well $\mathrm{F} 7$ begins to rise sharply within 2 to 3 hours after the start of a heavy rain. Several hours after the rain stops, the water level begins to fall, sharply at first and then more gradually during a long period of little or no rainfall. A similar sharp rise in water level occurs in well Si 79 no more than a few hours after the beginning of heavy rainfall. Well $\mathrm{F} 7$, which is at the crest of a ridge, apparently taps unconfined ground water. In the vicinity of the well a discontinuous mantle of till no more than a few feet thick overlies somewhat weathered, porous basalt, making it possible for infiltrating precipitation to reach the water table soon after the beginning of a rain. Well Si 79, however, presumably is cased to bedrock through 175 feet of stratified drift, chiefly fine sand and silt, and clearly taps confined ground water. The prompt rise in water level in this well following heavy rains suggests that the load of the infiltrating precipitation must be transmitted efficiently either through the thick sequence of stratified drift near the well or through the bedrock from a thinly till-covered area 1,300 feet to the west.

\section{LONG-TERM TRENDS}

The period during which water-level measurements have been made in observation wells within the Farmington-Granby area is too brief to indicate any long-term upward or downward trend in water levels. 
Records dating back to 1946 for observation wells elsewhere in Connecticut, however, are on file at the Connecticut office of the Branch of Ground Water. On the basis of these records, no long-term general rise or decline of the water table is evident in Connecticut.

\section{MAXIMUM RANGE OF FLUCTUATION}

The difference between the highest and lowest water level measured in each observation well in the Farmington-Granby area is shown by the hydrographs and summarized as follows:

MAXIMUM RANGE OF FLUCTUATION

["Greater than" symbol $(>)$ is used for wells that were dry or flowing at least once when measured]

\begin{tabular}{|c|c|c|c|c|c|}
\hline Well & $\begin{array}{l}\text { Range } \\
\text { (feet) }\end{array}$ & Well & $\underset{\text { (feet) }}{\text { Range }}$ & Well & $\begin{array}{l}\text { Range } \\
\text { (feet) }\end{array}$ \\
\hline $\begin{array}{l}\text { EG } 32 \ldots \ldots \\
\text { Si } 122 \ldots \ldots \\
\text { Si } 45 \ldots \ldots \\
\text { A } 13 a_{\ldots} \ldots \ldots\end{array}$ & $\begin{array}{r}11.79 \\
11.21 \\
>6.63 \\
>11.27\end{array}$ & $\begin{array}{l}\text { EG } 33 \\
\text { Si } 50 \\
\text { A } 93 \\
\text { F } 7\end{array}$ & $\begin{array}{l}\text { 11. } 40 \\
\text { 16. } 94 \\
29.45 \\
15.02\end{array}$ & $\begin{array}{l}\text { EG } 35 \ldots \ldots \\
\text { Si } 79 \ldots \\
\text { Si } 49 \\
\text { Si } 49\end{array}$ & $\begin{array}{r}11.65 \\
>5.23 \\
>40.21 \\
5.15\end{array}$ \\
\hline
\end{tabular}

Ordinarily, the maximum range of fluctuation over so brief a period of record would mean little, but all these wells except Si 79 and F 7 were measured both in the fall of 1955 , when unprecedented heavy rainfall raised most observation wells in Connecticut to or nearly to their highest levels since at least 1946, and in the fall of 1957, when a prolonged drought brought most observation wells in the State to or nearly to record lows. Hence, it is not likely that the maximum and minimum levels recorded for these wells will be substantially exceeded in the near future.

\section{EFFECT OF GEOLOGY AND TOPOGRAPHY}

Geology and topography affect.the amplitude of water-level fluctuations in wells in Connecticut, as shown by LaSala (1961). Stratified drift, which occurs mainly in valleys and lowlands, has more usable storage space and is more permeable than till, which occurs mainly on hills. In periods of general recharge and rising water levels, consequently, the stratified drift transmits water rather rapidly to the streams, and the rate of rise is not as pronouneed as in the till where storage space is more readily filled and water is transmitted much more slowly. In periods of declining water level, the rate of decline in the stratified drift is slowed by the-steady addition of ground water moving downslope from areas of till and bedrock. Thus water-level fluctuations in stratified drift are generally of smaller amplitude than those in till. For example, fluctuations in well Si 45 are much smaller 
than those in wells Si 122 and EG 32 (fig. 13). Well A 13a, however, though finished in stratified drift, has fluctuations about as large as those in the two till wells.

Water-level fluctuations in wells in bedrock commonly resemble those in the local surficial deposits. For example, note the close similarity of the hydrographs and the ranges of fluctuation for EG 32 and EG 33, or Si 45 and Si 79 . Thus, wells in bedrock beneath drumlins or till-covered uplands tend to have larger water-level fluctuations than those beneath valleys filled with stratified drift. All the drilled observation wells in this report except Si 79 are from till-covered areas. Other natural factors, however, including the geometry of the bedrock fracture systems, are also important, as illustrated by the wide difference in amplitude of fluctuation of nearby wells Si 49 and Si 50 .

\section{MAXIMUM RANGE OF FLUCTUATION}

The water level declines in the vicinity of a well when water is withdrawn from it. Under water-table conditions, the water table near a pumping well approximates a cone-shaped surface which is lowest at the well where the ground-water discharge is taking place and slopes toward that point from all directions. (See fig. 15.) Under artesian conditions, withdrawal reduces the artesian pressure at the well, so that a similar cone of depression develops in the piezometric (pressure) surface around the well. In either case the amount of drawdown and the size of the area of influence depend principally on the rate of withdrawal, the permeability and storage capacity of the aquifer, and the time elapsed since pumping began.

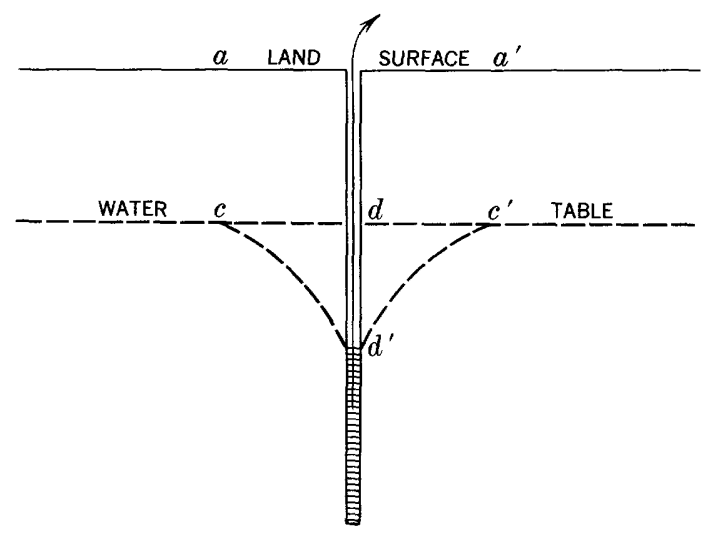

Figure 15.-Diagrammatic section of a well that is being pumped, showing its drawdown $\left(d d^{\prime}\right)$, cone of depression $\left(c d^{\prime} c^{\prime}\right)$, and area of influence $\left(a a^{\prime}\right)$. 
Because population growth has resulted in an increasing number of areas of closely spaced domestic wells, it is important to know the extent to which wells in such areas interfere with one another. Data from observation well EG 33, which taps sedimentary bedrock of the Newark group, provides an example of water-level fluctuatious caused by normal daily pumping from several closely spaced domestic bedrock wells under one particular set of conditions. A continuous record of water-level fluctuations in this well for a period of 19 months, from August 1956 to March 1958, was examined in detail. A short segment of this record is shown in figure 16 , and major fluctuations during the entire period are shown in figure 14. Three domestic wells were in use near EG 33 prior to September 1957, and four wells during the rest of the period of record. These wells were at distances of $183,200,300$, and 325 feet from EG 33. Other domestic wells farther away were also in use.

The daily water-level fluctuations recorded at EG 33 evidently reflect the pumping of the nearby wells. A steady rise in water level took place each night between about 11:00 p.m. and about 6:00 a.m., the period when domestic wells are least used. In order to obtain a further check on the effect of nearby pumping, a nearby homeowner was asked to record the time when his pump was first running on one particular day, and this time (5:50 to $6: 10$ a.m.) agreed closely with the beginning of water-level decline in well EG 33 on that day. The pattern of fluctuation in EG 33 after $6: 00$ a.m. was variable, but frequently a low occurred between midmorning and noon, particularly during the winter. The low was followed by an irregular rise to a secondary peak sometime between 2:00 and 8:00 p.m. and then a decline to a second low in the late evening, usually at 10:00 to 12:00 p.m. This pattern corresponds to the normal pattern of water use in homes and pumping from domestic wells.

The amplitude of the daily water-level fluctuations in well EG 33 also was variable, being generally largest in the summer when domestic water usage is at a peak. During the period from June 13 to Jume 27,1957 , in which there was virtually no precipitation and the air temperature at Bradley Field averaged $7^{\circ}$ above the normal of $70^{\circ}$ $\mathrm{F}$, the mean daily water-level fluctuation in the well was 1.09 feet. The maximum fluctuation within a 24 -hour period in 1957 was 2.39 teet, and it occurred on .June 18th. On the other hand, between November 1 and November 15, 1957, which was a somewhat cloudy rainy period, the mean daily fluctuation was 0.38 feet. Over a period of a year, the mean daily fluctuation probably would be between 0.5 and 0.7 foot. Interference of the magnitude recorded by well EG 33 is not large enough to be a problem in domestic drilled wells. 


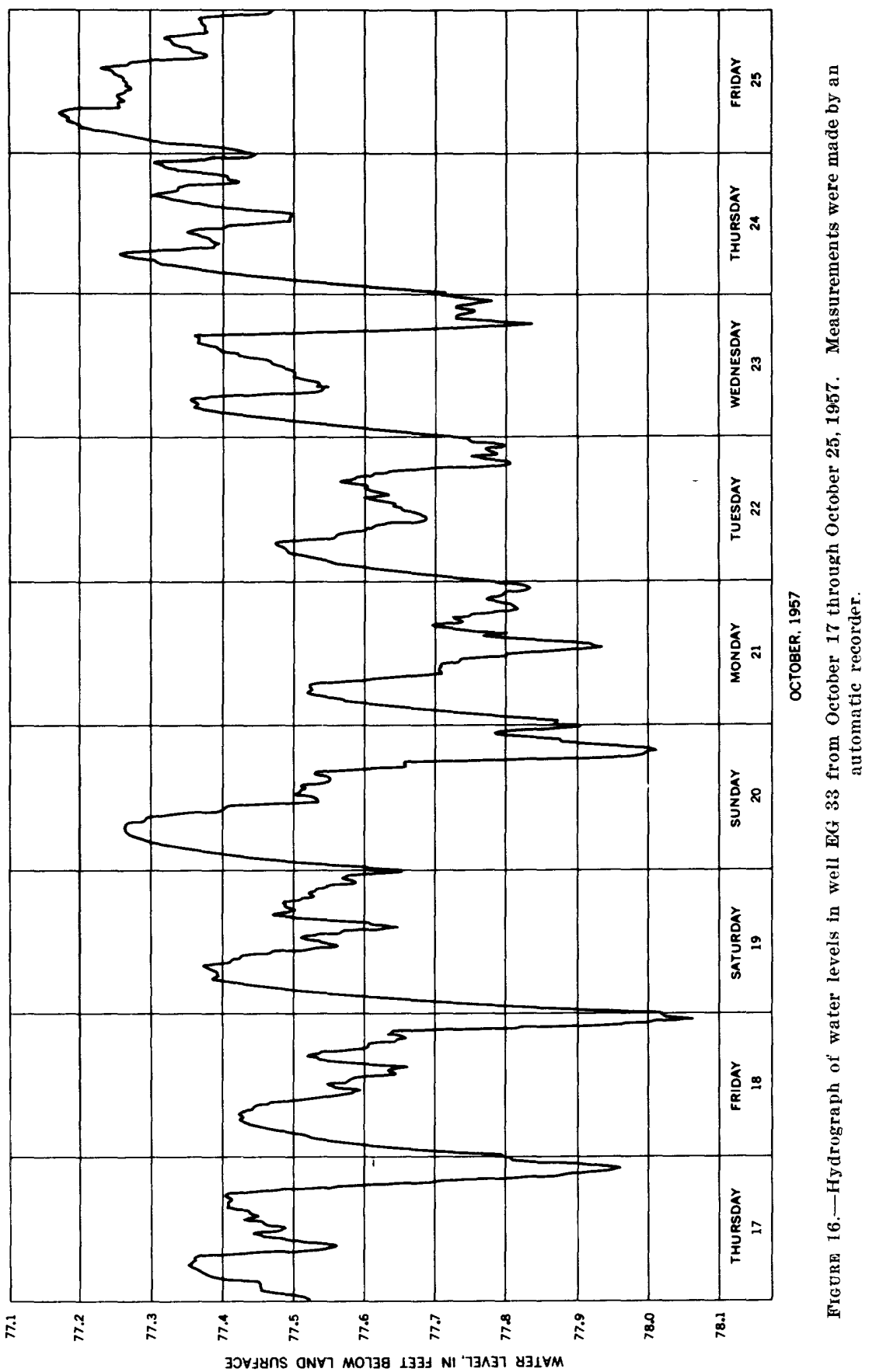


The foregoing analysis has shown that the pumping of nearby domestic wells causes only a small daily fluctuation in well EG 33, but whether or not such pumping has resulted in long-term lowering of local water levels is more difficult to determine. If there had been no nearby pumping at all, the water level in well EG 33 would probably have been at least a few tenths of a foot higher than the recorded daily maxima, as nowhere do rising segments of the hydrographs of daily fluctuations level off so as to suggest that a static level was reached. Some evidence, however, suggests that water levels in this locality are not greatly different from what they would be under natural conditions. The form of the yearly hydrograph (fig. 14), prepared from the daily highs on 2 or 3 days in each month, suggests that the times of recharge and discharge are about the same as in most of the other observation wells, and the maximum range of seasonal variation is also about average. The considerable depth to water in well EG 33 and nearby wells is typical of water levels below drumlins.

Sustained pumping from high-capacity wells may have a pronounced effect on water levels in nearby wells. For example, when well $\mathrm{Si} 51 \mathrm{a}$ was pumped steadily for $21 / 2$ hours at about $80 \mathrm{gpm}$, the water level in well Si 113, which is 645 feet away, declined 12.2 feet. and the water level in well $\mathrm{Si} 79$, which is 1,515 feet away, declined 3.4 feet. Pumping for a longer period would have resulted in somewhat greater declines.

\section{TYPES OF WELLS AND SPRINGS}

Ground-water supplies in the Firmington-Granby area are obtained almost entirely from drilled, driven, and dug wells and from springs. Most wells courstructed since around 1935 have been drilled wells. Dug and driven wells and springs are still widely used, however, and under suitable conditions can provide quite satisfactory supplies at relatively low cost. Test borings for various purposes are commonly put down by jetting ("wash boring") methods.

\section{DRILLED WELLS}

Most drilled wells are constructed by cable-tool or rotary methods. They are more costly to construct than the other types of wells, but if properly constructed they are likely to give longer trouble-free service and are more easily kept free of contamination. (See, however, the section of this report entitled "Bacterial contamination in ground water.") Furthermore, only drilled wells can penetrate more than small thicknesses of bedrock; the other types of wells are almost entirely restricted to production from the unconsolidated deposits. 
Most drilled wells tap water in bedrock, but excellent wells have been finished in stratified 'drift in many places. Such wells, especially those finished with a screen rather than open-end casing, commonly have higher yields and specific capacities than bedrock wells.

\section{JETTED WELLS}

Jetted wells, or "wash borings,": are.constructed by pumping water down a $11 / 4$ - to $21 / 2$-inch open-end pipe from which the water washes against the earth materials below. Although many small-capacity wells are put down by this method in 'some parts of the United States, in the Farmington-Granby area the method has apparently been used chiefly to sink stest wells ands test.borings for bridge and building foundations. These borings generally proceed to "refusal," which may be the top of the consolidated bedrock or, sometimes, a large boulder.

\section{DRIVEN WETLS}

In favorable areas, driven wells may be constructed more easily and inexpensively than any other type of well. They are put in by driving into the ground successive lengths of pipe, generally $11 / 1$ to $21 / 2$ inches in diameter, with a screened drive point on the bottom. The depth to which wells may be driven is limited by the frictional resistance of the material penetrated. Under favorable conditions, 2-inch wells can be driven 100 feet or more in sand and fine gravel, although no driven. wells deeper than 72 feet are recorded from the Farmington-Granby area. It is usually a simple matter to drive a well a little deeper if the water table declines below the bottom of the well.

Driven wells are restricted to areas underlain by stratified drift or alluvium. Where layers of till or coarse gravel are present within the stratified drift, however, it is difficult to drive the pipe throngh to the water table. The point should end in well-sorted stratified material whose average grain size is at least as large as fine sand and is suited to the size of the screen openings chosen. If a driven well continually pumps sand or fails very quickly because of the point clogging or filling with sand, driving a point with a finer screen to the same depth may result in a satisfactory well. The yield and useful life of many driven wells can be increased by initial development, in which some of the finer sand in the formation near the screen is removed by inducing a surging action in the water in the well.

The yields of driven wells in the Farmington-Granby area are generally less than $10 \mathrm{gpm}$, but larger supplies can be obtained from properly spaced wells pumped as a unit. 


\section{DUG WELLS}

Dug wells are excavated pits, roughly cylindrical in shape. Most are 2 to 5 feet in diameter, although dug wells 15 feet in diameter are in use within the Farmington-Granby area. They may be dug by hand, by clamshell bucket, or by power auger (wells dug by auger, referred to as "bored wells," are rare in the Farmington-Granby area). Almost every well is lined with some type of casing; fieldstone, brick, earthenware tile, and cement tile are commonly used.

Dug wells have several advantages. They are inexpensive, and skilled labor and expensive equipment are not required for construction. Also, their large diameter is helpful in obtaining water from materials of low permeability, such as glacial till and very fine sand, because large volumes of water can be stored within the well and short intermittent pumping does not require immediate release of water from the surrounding materials. Even so, however, the yield of many dug wells in such materials is not adequate to supply the quantity of water desired by many families. Most dug wells have the disadvantage of being relatively shallow, as it is difficult to extend them more than a few feet below the water table; consequently, unless they are dug or deepened during a period when the water table is unusually low, they may fail temporarily during prolonged dry spells. Furthermore, dug wells must be constructed with considerable care if there is to be reasonable assurance that they will not become contaminated. Water-tight casing should extend from the surface to a depth of several feet, preferably below the water table; the well should be fitted with a tight cover to prevent animals and loose objects from falling in; and the slope of the surrounding land surface should be adjusted so that surface water cannot flow to the edge of the casing. A diagram and recommendations for proper well construction are provided in a pamphlet by the Connecticut State Department of Health (1948).

Records of 67 dug wells were collected for this report; they are compiled separately as part of a U.S. Geological Survey open-file report. In addition, information may be obtained from reports covering the Farmington-Granby area by Palmer (1920, 1921), which were published at a time when dug wells outnumbered all other types combined. These reports contain records of a large number of dug wells, and a discussion of yields of such wells and descriptions of common lifting devices.

\section{SPRINGS}

Springs are found at many places within the Farmington-Granby area, but they are most common near the base of steep slopes and 
along the sides of small valleys cut into flat to moderately sloping land. Several combinations of topographic and geologic conditions can cause a spring. Probably the most common type of spring is the contact spring, so called because the water issues along the contact of a permeable aquifer with underlying relatively impermeable material. For example, when water is percolating downward through surficial stratified deposits and encounters till or bedrock, it is prevented from continuing downward except at a much slower rate; hence a eonsiderable part of the water is deflected laterally along the contact and may emerge as a spring where the contact is exposed on a valley wall. Springs $\mathrm{A} 2$ and 4 and $\mathrm{Gr} 2,6$, and 13 are probably contact springs, and spring Si 3 may be also (see table 12). All these springs occur along the sides of valleys cut into flat to moderately sloping land.

Another type of spring, termed a depression spring, emerges where the land surface intersects the water table. Such springs are found chiefly at the base of slopes or in relatively low-lying areas, particularly along stream banks. Springs F 1 and Gr 7 may be depression springs. Seepage of ground water into stream channels, in which it becomes base flow, is similar, but this seepage is generally too diffuse to be identified as springs.

In a few springs, such as spring Gr 9, the water issues from fractures in the bedrock. The water in some fracture springs is under considerable artesian pressure.

Perennial springs are a convenient and economical source of water. Many small springs in the Farmington-Granby area dry up during the summer, however, and in other springs the flow is much reduced. Most springs in use at the time of this investigation supply only small quantities of water for domestic and farm purposes, although one (spring $\mathrm{Si} 3$ ) is the source of a public water supply that furnished 38 customers (an estimated. 125 persons) with water in 1956. Many springs are unused.

If a spring is to be used for-household supply, safety demands that no source of contamination be allowed near it, and that the reservoir be constructed to standards similar to those for a dug well; that is, it must be built of durable materials, properly covered to keep out falling debris and small animals, and protected from surface wash. Recommendations for the construction of spring reservoirs are provided in a Connecticut State Department of Health pamphlet (1948). 
TABLE 12.-Records of selected springs

Location: Location system explained in text.

Approximate altitude: Estimated from topographic map.

\begin{tabular}{|c|c|c|c|c|c|c|}
\hline $\begin{array}{l}\text { Spring } \\
\text { No. }\end{array}$ & Location & Owner & $\begin{array}{l}\text { Topographic } \\
\text { situation }\end{array}$ & $\begin{array}{c}\text { Ap- } \\
\text { proxi- } \\
\text { mate } \\
\text { altitude } \\
\text { (ft) }\end{array}$ & $\begin{array}{l}\text { Number } \\
\text { of } \\
\text { openings }\end{array}$ & $\begin{array}{l}\text { Water-yielding } \\
\text { unit }\end{array}$ \\
\hline A 2 sp..... & H7-5eb-- & $\begin{array}{l}\text { C. F. \& C. R. } \\
\text { Woodford. }\end{array}$ & $\begin{array}{l}\text { Side of small valley } \\
\text { along hillslope. }\end{array}$ & 250 & $\begin{array}{l}\text { Several; } \\
1 \text { used. }\end{array}$ & $\begin{array}{l}\text { Ground-moraine } \\
\text { deposits(?). }\end{array}$ \\
\hline A 4 sp..... & G7-8cf -- & Bisberg & $\begin{array}{l}\text { Axis of shallow } \\
\text { valley along steep } \\
\text { hillslope. }\end{array}$ & 420 & $1 \ldots \ldots$ & $\begin{array}{l}\text { Ground-moraine } \\
\text { deposits. }\end{array}$ \\
\hline F 1sp...... & $\mathrm{H} 6-1 \mathrm{ae}$ & Joseph Lorencik -- & $\begin{array}{l}\text { Low terrace, base } \\
\text { of hillslope. }\end{array}$ & 200 & 4 or $5 \ldots$ & $\begin{array}{l}\text { Ice-contact } \\
\text { deposits. }\end{array}$ \\
\hline Gr 2sp.... & H9-7gf.- & Wilhelm Bechle & $\begin{array}{l}\text { Middle of steep } 35- \\
\mathrm{ft} \text { valley side. }\end{array}$ & 580 & $\ldots$ & $\begin{array}{l}\text { Ground-moraine } \\
\text { deposits. }\end{array}$ \\
\hline Gr $6 s p$ & H8-2aa.- & $\ldots-$ & $\begin{array}{l}\text { Middle of steep } 25- \\
\mathrm{ft} \text { valley side. }\end{array}$ & 300 & Several & $\begin{array}{l}\text { Ice-contact } \\
\text { deposits. }\end{array}$ \\
\hline Gr 7sp.... & H8-3de.-- & $\begin{array}{l}\text { Freeman, Kate, } \\
\text { and Yager. }\end{array}$ & $\begin{array}{l}\text { Axis of wind gap, } \\
\text { very steep slopes } \\
\text { on both sides. }\end{array}$ & 235 & $4 \ldots$ & \\
\hline Gr 9sp.... & H8-3gf-- & $\begin{array}{l}\text { William D. } \\
\text { Endress. }\end{array}$ & Gentle hillslope.....- & 260 & $1 \ldots$ & Newark group, s.- \\
\hline Gr 13sp... & H9-7de-- & Theodore Shattuck & $\begin{array}{l}\text { Small valley on up- } \\
\text { land flat. }\end{array}$ & 540 & & $\begin{array}{l}\text { Ground-moraine } \\
\text { deposits. }\end{array}$ \\
\hline Si 3sp..... & H8-8fe - - & $\begin{array}{l}\text { Westover Plain } \\
\text { Water Co. }\end{array}$ & $\begin{array}{l}\text { Stream valley, base } \\
\text { of gentle slope. }\end{array}$ & 220 & $\begin{array}{l}\text { Several; } \\
1 \text { used. }\end{array}$ & $\begin{array}{l}\text { Ice-contact de- } \\
\text { posits(?) }\end{array}$ \\
\hline
\end{tabular}




\section{in the Farmington-Granby area}

Water-yielding unit: Newark group, s indicates sedimentary rock within the Newark group; other terms not abbreviated.

Use: Dom, domestic; Farm, general farm purposes (may include stock watering and domestic use at farmhouse); Irr, irrigations; PS, Public supply; Un, unused or abandoned.

\begin{tabular}{|c|c|c|c|c|c|}
\hline Nature of source & $\begin{array}{l}\text { Improvements, } \\
\text { accommodation }\end{array}$ & Yield & $\begin{array}{l}\text { Fluctuation, } \\
\text { dependability }\end{array}$ & Use & Remarks \\
\hline $\begin{array}{l}\text { Apparently near } \\
\text { contact of till } \\
\text { on shale bed- } \\
\text { rock. }\end{array}$ & $\begin{array}{l}\text { Stone masonry } \\
\text { housing } 2-\mathrm{ft} \text { di- } \\
\text { ameter; cover; } \\
\text { piped 1,200 ft } \\
\text { by gravity to } \\
\text { several } \\
\text { buildings. }\end{array}$ & & $\begin{array}{l}\text { Reported un- } \\
\text { failing, but } \\
\text { water level } \\
\text { low in dry } \\
\text { summers. }\end{array}$ & Farm . . & $\begin{array}{l}\text { Temperature } \\
50^{\circ} \text {, July 1, } \\
1953 \text {; supplies } \\
2 \text { houses and } \\
2 \text { barns. }\end{array}$ \\
\hline $\begin{array}{l}\text { Contact of sandy } \\
\text { till on gneiss } \\
\text { bedrock; up- } \\
\text { slope side. }\end{array}$ & $\begin{array}{l}\text { Reservoir pit } 5 \text { by } \\
15 \mathrm{ft}, 2 \mathrm{ft} \text { deep, } \\
\text { dug out and } \\
\text { dammed with }\end{array}$ & $\begin{array}{l}\text {.2eported } 15 \\
\text { gpm in the } \\
\text { spring. }\end{array}$ & $\begin{array}{l}\text { Reported to dry } \\
\text { up about } \\
\text { July } 1 .\end{array}$ & Un..... & $\begin{array}{l}\text { Occasionally } \\
\text { used for stock. }\end{array}$ \\
\hline $\begin{array}{l}\text { Water bubbles } \\
\text { up through } \\
\text { sand; may be } \\
\text { depression } \\
\text { spring. }\end{array}$ & $\begin{array}{l}\text { Small pit dug } 1 \\
\text { ft deep. }\end{array}$ & $\begin{array}{l}\text { Estimated } 1 \text { to } \\
2 \text { gpm Sept. } 7 \text {, } \\
1954 .\end{array}$ & $\begin{array}{l}\text { Reported } \\
\text { unfailing. }\end{array}$ & Un..... & $\begin{array}{l}\text { Occasionally } \\
\text { used for } \\
\text { drinking. }\end{array}$ \\
\hline $\begin{array}{l}\text { Probably contact } \\
\text { of thin sand } \\
\text { and gravel } \\
\text { mantle on till. }\end{array}$ & $\begin{array}{l}\text { Springhouse, res- } \\
\text { ervoir house } \\
\text { (filled by grav- } \\
\text { ity flow), } \\
\text { pumphouse; } \\
\text { water pumped } \\
\text { across road to } \\
\text { farm. }\end{array}$ & $\begin{array}{l}\text { Often pumped } \\
2,000 \text { gpd. }\end{array}$ & $\begin{array}{l}\text { Used for several } \\
\text { years, owner } \\
\text { reports plenty } \\
\text { of water at } \\
\text { all times. }\end{array}$ & $\begin{array}{c}\text { Farm, } \\
\text { Irr. }\end{array}$ & $\begin{array}{l}\text { Used for apple } \\
\text { spraying; } \\
\text { formerly sup- } \\
\text { plied several } \\
\text { houses. }\end{array}$ \\
\hline $\begin{array}{l}\text { Contact of sand } \\
\text { and gravel on } \\
\text { Triassic sand- } \\
\text { stone. }\end{array}$ & $\begin{array}{l}\text { None; main flows } \\
\text { issue from } \\
\text { small openings } \\
\text { in the soil ap- } \\
\text { parently } \\
\text { washed out by } \\
\text { the water. }\end{array}$ & $\begin{array}{l}\text { Estimated } 5 \text { to } \\
10 \text { gpm Oct. } \\
24,1955 .\end{array}$ & $\begin{array}{l}\text { Unknown, but } \\
\text { small seepage } \\
\text { Oct. } 6,1956, \\
\text { so may be } \\
\text { perennial. }\end{array}$ & Un & \\
\hline $\begin{array}{l}\text { Openings in base } \\
\text { of talus deposit; } \\
\text { water may seep } \\
\text { from mountain } \\
\text { directly or by } \\
\text { way of a slightly } \\
\text { higher swampy } \\
\text { area of sand de- } \\
\text { posits in and } \\
\text { west of gap. }\end{array}$ & $\begin{array}{l}3 \text { spring pits dug } \\
\text { out, stoned up, } \\
\text { covered. }\end{array}$ & $\begin{array}{l}\text { Flow of spring- } \\
\text { brook esti- } \\
\text { mated } 4 \text { to } 5 \\
\text { gpm oct. } 28 \text {, } \\
1956 \text {. }\end{array}$ & $\begin{array}{l}\text { Famous locally } \\
\text { for depend- } \\
\text { ability. }\end{array}$ & $\begin{array}{l}\text { Dom, } \\
\text { Farm. }\end{array}$ & $\begin{array}{c}\text { Temperature } 50^{\circ} \\
\text { Oct. } 28,1956 .\end{array}$ \\
\hline Fracture in rock... & $\begin{array}{c}\text { 36-in. pit, dug } 2 \mathrm{ft} \\
\text { deep, upper } 1 \mathrm{ft} \\
\text { cemented, plank } \\
\text { cover;.gravity } \\
\text { flow to reservoir } \\
\text { at house across } \\
\text {-street, pumped } \\
\text { into house. }\end{array}$ & $\begin{array}{l}\text { Flows continu- } \\
\text { ously at esti- } \\
\text { mated } 1 / 4 \text { gpm. }\end{array}$ & $\begin{array}{l}\text { Supply reported } \\
\text { sometimes lim- } \\
\text { ited in sum- } \\
\text { mer. }\end{array}$ & Dom... & $\begin{array}{l}\text { Similar springs } \\
\text { nearby. }\end{array}$ \\
\hline $\begin{array}{l}\text { At or just bèlow } \\
\text { contact of sand } \\
\text { mantle on clay } \\
\text { or till. }\end{array}$ & $\begin{array}{l}\text { Pit } 4 \text { x } 7 \mathrm{ft}, 4 \text { ft } \\
\text { deep, walled } \\
\text { with stone; flat } \\
\text { wood cover; over- } \\
\text { flow pipe; pump } \\
\text { line to house. }\end{array}$ & $\begin{array}{l}\text { Overflowing at } \\
\text { estimated } 3 \\
\text { gpm Nov. 25, } \\
1955 \text {. }\end{array}$ & $\begin{array}{l}\text { Used } 9 \text { to } 10 \\
\text { years, water } \\
\text { level reported } \\
\text { always up to } \\
\text { overflow pipe. }\end{array}$ & Un..... & $\begin{array}{l}\text { Former doinestic } \\
\text { supply. }\end{array}$ \\
\hline $\begin{array}{l}\text { Water reported to } \\
\text { bubble up } \\
\text { through sand a- } \\
\text { round a large } \\
\text { rock in spring } \\
\text { pit. }\end{array}$ & $\begin{array}{l}\text { Pit } 16 \times 20 \mathrm{ft}, 81 / 2 \\
\text { ft deep; } 10-\mathrm{ft} \\
\text { stone masonry } \\
\text { wall } 16 \text { in. thick, } \\
\text { extensive distri- } \\
\text { bution system. }\end{array}$ & - & $\begin{array}{l}\text { Supply always } \\
\text { adequate; wa- } \\
\text { ter level re- } \\
\text { ported to drop } \\
1 \text { to } 2 \mathrm{ft} \text { in dry } \\
\text { summer. }\end{array}$ & PS....- & $\begin{array}{l}\text { Used since } 1909 \\
\text { as a public sup- } \\
\text { ply; 38 custom- } \\
\text { ers in Jan. 1956, } \\
\text { including } 3 \text { ga- } \\
\text { rages and sev- } \\
\text { eral stores; } \\
\text { chemical anal- } \\
\text { ysis given in } \\
\text { table 13. }\end{array}$ \\
\hline
\end{tabular}




\section{QUALITY OF GROUND WATER}

Sixty-two analyses of water samples from wells and springs in the Farmington-Granby area were obtained for this report and are presented in table 13. Sixteen of these are relatively complete analyses made by the U.S. Geological Survey. The samples were collected from wells so chosen by the writer as to provide several examples of water from each of the aquifers in the area covered by this investigation. Supplementary information is provided by 46 partial inalyses made by the Connecticut State Department of Health, by several commercial or industrial concerns, and by the U.S. Geological Survey.

The dissolved chemical constituents of water are expressed in parts per million (ppm) in these analyses. A part per million is a unit weight of a constituent in a million unit weights of water. For example, if water is found to contain $30 \mathrm{ppm}$ of calcium, 1 million pounds of the water would contain 30 pounds of calcium.

\section{CHEMICAL CHARACTERISTICS OF GROUND WATER}

The chemical characteristics of ground water of the FarmingtonGranby area are represented graphically in a diagram (fig. 17) based on the results of 18 chemical analyses. The diagram was developed and its use described by Piper (1944). To plot an analysis, concentrations must be expressed in equivalents per million, which are computed by dividing the concentration of each ion in parts per million by the equivalent weight of that ion. (The equivalent weight is obtained by dividing the ionic weight by the valence.) The sum of the cation equivalents in the analysis should equal the sum of the anion equivalents. The less common ions are grouped with the major anions or cations with which they are generally associated (potassium with sodium, fluoride and nitrate with chloride, carbonate with bicarbonate) and the concentration of each of the three major cation groups (calcium, magnesium, sodium) and three major anion groups (bicarbonate, sulfate, chloride) is expressed as a percentage of the sum total of cation or anion equivalents, respectively, and plotted on the diagram.

The diagram shows that most samples of ground water in the Farmington-Granby area are similar in chemical character. The bicarbonate ion is the dominant anion in almost all samples, sulfate is subordinate, and the chloride content is very low. Even in three samples containing over $2,000 \mathrm{ppm}$ total solids, chloride and nitrate together constitute no more than $8 \mathrm{ppm}$. Bicarbonate is particularly dominant in water from bedrock (especially that from the Newark group) and in water from deep parts of the stratified drift. 
Most water has calciun as the dominant cation, although some of the deeper wells in the Newark group yield wates high:in sodium. The chemical character of water high in total mineral content does not deviate in any systematic manner from the average chemical character.

\section{QUALITY AS RGLATED TO SOURCE}

Despite the basic similarity in chemical characteristics of the samples of ground water from the Farmington-Granby area, some noteworthy differences appear between samples from different lithologic units and between some samples from a single unit.

Water from the Newark group is harder than most water from the crystalline rocks or the stratified glacial deposits; it also is higher in total mineral content and in most individual mineral constituents. These differences are shown by analyses included in older water-supply papers covering central Connecticut (Palmer, 1920, p. 62-64; 1921, p. 64-65), as well as by more recent data collected by the writer. In addition, wells yielding water of somewhat unusual chemical composition are more common in the Newark group. For example, the sodium, carbonate, and fluoride content is unusually high in water from well $\mathrm{Gr} 26$, the sulfate content is high in water from well A 39, and the sodium content is high in water from-well F 78. Another difference is that the $\mathrm{pH}$ of most water from the Newark group is 7.0 or higher, whereas the $\mathrm{pH}$ of most water from the other aquifers is 7.0 or below. Of 26 water samples from the Newark group, only 6 had a $\mathrm{pH}$ below $7.0 ; 5$ of these were from wells that had only 11 to 20 feet of casing, which suggests that the low $p H$ could be due to water that entered these wells near the surface and had only brief eontact with the carbonate-rich bedrock.

Within the Newark group the mineral content of ground water tends to increase with well depth, though there are many exceptions to this pattern. In addition, many of the wells finished in either trap rock or sedimentary rock along Talcott Mountain, or near the intrusive body lower in the Newark section, yield water that is higher in mineral content than that obtained from other parts of the Newark group. Water from a few of the wells along Talcott Mountain contains the most mineral matter of any water in the Farmington-Granby area. Water samples from wells A 39 and Si 39, near the base of the west face of this ridge, contained 501 and $814 \mathrm{ppm}$ dissolved solids, respectively; samples from wells $F 22$ and F 73, just west of the crest of the ridge; contained 2,510 and 2,290 ppm dissolved solids, respectively; and a sample from well F 91 in Oakland Gardens, east of the ridge crest, had a hardness of $2,500 \mathrm{ppm}$ as $\mathrm{CaCO}_{3}$. Many other rock wells along this ridge yield water whose mineral content is slightly to moderately above the average for the report area. 


\section{TABLE 13.-Chemical analyses of water from}

Analytical results in parts per million except specific conductance and $\mathrm{pH}$; $\mathrm{Tr}$, trace.

Location: Location system explained in text.

Water-yielding unit: Newark group, $s$ indicates sedimentary rock within the group; Newark group, b indicates igneous rock within the group; Hartland formation, g indicates gneiss bodies within the formation: Collinsville gneiss indicates the Collinsville gneiss of Rodgers and others (1956).

Dissolved solids: Residue on evaporation at $180^{\circ} \mathrm{C}$ in U.S. Geol. Survey analyses; residue on evaporativn after heating platinum dish to a "low dull red" in Newlands Sanitary Laboratory analyses.

\begin{tabular}{|c|c|c|c|c|c|c|c|c|c|c|c|}
\hline $\begin{array}{l}\text { Well } \\
\text { No. }\end{array}$ & Location & 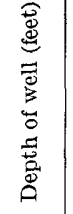 & 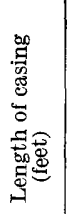 & Water-yielding unit & $\begin{array}{l}\text { Date of } \\
\text { collection }\end{array}$ & 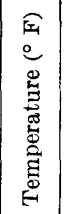 & 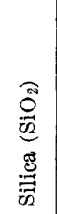 & 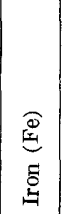 & 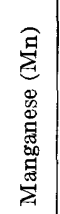 & 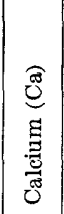 & 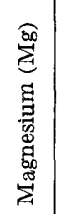 \\
\hline & $7-7 \mathrm{bo}$ & 24 & 21 & Ice-contact de & Jan. $\quad 2,1956$ & 53.3 & 11 & 0.03 & 0.00 & 15 & 1.7 \\
\hline & $\mathrm{H} 7$ & 108 & 85 & $\begin{array}{l}\text { Ice-contact deposits } \\
\text { and Newark } \\
\text { group, s. }\end{array}$ & Dec. 10,1954 & 80.0 & & .1 & & . & \\
\hline A 29. & $\mathrm{H} 7-5 \mathrm{dd}$ & 26 & 21 & Valley-train deposits & $\begin{array}{l}\text { Dec. } 14,1953 \\
\text { Mar. } 10,1955\end{array}$ & $\ldots$ & 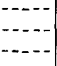 & $\begin{array}{l}.15 \\
.1 \\
.1\end{array}$ & & $\mid \cdots-$ & \\
\hline A 39 & $\mathrm{H} 7-8 \mathrm{bg}$. & 140 & $40 \pm$ & Newark group, s..... & Nov, 10,1955 & & 25 & 0 & & 63 & 12 \\
\hline A $62 \ldots$ & $\mathrm{H} 7-4 \mathrm{ja} \mathrm{a}_{--}$ & 87 & 28 & _._. do do.... & Jan. 7,1956 & 54 & 13 & .04 & .00 & 19 & 1.8 \\
\hline A 68 & G7-9be -- & 101 & 30 & Collinsville gneiss... & _._. $d o_{-}$ & 51 & 10 & .21 & .04 & 5.7 & 1.6 \\
\hline A $70 \ldots$ & H7-8ea-- & 238 & 30 & New & 1950 & & & & & & \\
\hline A 81 & H7-5bg-- & 82 & 82 & Ice-contact deposits. - & $\begin{array}{l}\text { Nov. } 24,1915 \\
\text { Jan. } 5,1956\end{array}$ & 50 & 14 & .26 & .00 & 25 & 3.1 \\
\hline EG 9..- & H8-6ee-- & 118 & $100 \pm$ & Newark group, s..... & Nov. 18,1916 & & 18 & .68 & & 14 & 2.6 \\
\hline F 3 & $\mathrm{H} 6-2 \mathrm{ag}$. & 120 & 120 & Valley-train deposits_ & May 1,1956 & 52 & 14 & .17 & .01 & 22 & 1.6 \\
\hline F 6 . & II6-1bd . & 37 & 37 & Ice-contact deposits & Jan. $\quad 2,1956$ & 54 & 12 & .33 & .00 & 21 & 2 \\
\hline F $9 \ldots$ & H6-3eh.- & 233 & 16 & Newark group & Apr. 7,1 & & & $<.1$ & & & \\
\hline $\begin{array}{l}\text { F } 16 \ldots \\
\text { F } 20 \ldots \\
\text { F } 21 \ldots\end{array}$ & $\begin{array}{l}\mathrm{H} 6-2 \mathrm{ej}-- \\
\mathrm{H} 7-8 \mathrm{hj}-- \\
\mathrm{H} 6-2 \mathrm{bg}_{--}\end{array}$ & $\begin{array}{c}55 \\
353 \\
230 \pm\end{array}$ & $\begin{array}{l}12 \pm \\
41 \\
82\end{array}$ & 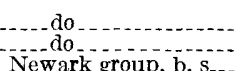 & $\begin{array}{l}\text { Uct. } \\
\text { Jan. } \\
\text { Jan. } \\
\end{array}$ & $\begin{array}{l}54.8 \\
53.7\end{array}$ & $\begin{array}{l}24 \\
13\end{array}$ & $\begin{array}{l}.1 \\
.36 \\
.16\end{array}$ & .01 & 31 & $\begin{array}{l}9.3 \\
5.3\end{array}$ \\
\hline $\begin{array}{l}\text { F } 22 \\
\text { F } 26\end{array}$ & $\begin{array}{l}\text { H6-2ee.- } \\
\text { H6-2be.- }\end{array}$ & 390 & $\begin{array}{c}82 \\
14 \pm \\
100 \pm\end{array}$ & $\begin{array}{l}\text { k group, b, s--- } \\
\text { k group }\end{array}$ & June 27,1935 & & & 10 & & & \\
\hline & & 125 & & & Feb & & & & & & \\
\hline F $51 \ldots$ & $\begin{array}{l}\text { H6-2ab_- } \\
\text { H6-4ba.- }\end{array}$ & $\begin{array}{l}28 \\
48\end{array}$ & $\begin{array}{l}25 \\
45\end{array}$ & $\begin{array}{l}\text { Valley-train deposits } \\
\text { Ice-contact deposits }\end{array}$ & $\begin{array}{r}\text { Aug. } 23,1954 \\
1952\end{array}$ & & & & & & \\
\hline $\begin{array}{l}\text { F } 73 \ldots \\
\text { F } 76 \ldots\end{array}$ & $\begin{array}{l}\text { IH6-2eh-- } \\
\text { H6-2ab- }\end{array}$ & $\begin{array}{c}310 \\
55 \pm\end{array}$ & $\begin{array}{l}20 \\
52 \pm\end{array}$ & $\begin{array}{ll}\mathrm{Ne} \\
\mathrm{Va}\end{array}$ & Apr. $\quad 9,1$ & & & & & & \\
\hline F $78 \ldots$ & H6-4ac-- & 438 & 210 & & Jan. $\quad 7,1956$ & 51 & 16 & 20 & .01 & 17 & $1 . \overline{3}$ \\
\hline & I16-3eh.- & 132 & $15 \pm$ & Newark group. & Mar. 17, 1953 & & & & & & \\
\hline F 91 & H6-3ad- & 81 & 21 & . do & $\begin{array}{l}\text { Sept. } 22,1954 \\
\text { Sept. } 24,1951\end{array}$ & & & $<.1$ & & - & \\
\hline $\begin{array}{l}\text { F } 96 \ldots \\
\text { F } 110 \ldots\end{array}$ & $\begin{array}{l}\text { H7-7ga.- } \\
\text { H6-2eh.- }\end{array}$ & $\begin{array}{c}60 \pm \\
250\end{array}$ & $15 \pm$ & .... do . . & $\begin{array}{r}\text { Mar. } 31,1954 \\
\text { Summer, } 1956\end{array}$ & & & & & $\begin{array}{ll}\cdots \\
\cdots-\end{array}$ & $\cdots$ \\
\hline $\begin{array}{l}\text { Gr } 26 \ldots \\
\text { Gr } 66 \ldots \\
\text { Gr } 82 \mathrm{a}_{\ldots}\end{array}$ & $\begin{array}{l}\text { H8-4fe_- } \\
\text { H8-5ej_-- } \\
\text { H8-3aa_- }\end{array}$ & $\begin{array}{c}328 \\
921 / 6 \\
531 / 2\end{array}$ & $\begin{array}{l}37 \\
771 / 2 \\
501 / 2\end{array}$ & $\begin{array}{l}\text { Newark group, s } \\
\text { Ice-contact deposits. }\end{array}$ & $\begin{array}{ll}\text { Jan. } & 5,1956 \\
\text { Dec. } & 8,1954 \\
\text { Jan. } & \mathbf{2 , 1 9 5 6}\end{array}$ & $\begin{array}{l}53.7 \\
49.5\end{array}$ & 12 & $\begin{array}{r}.11 \\
: 08 \\
: 08\end{array}$ & $\begin{array}{r}.00 \\
.01\end{array}$ & $\begin{array}{r}8.1 \\
4 . \overline{8}\end{array}$ & $\begin{array}{l}1 . \\
1 .\end{array}$ \\
\hline
\end{tabular}




\section{wells and springs in the Farmington-Granby area}

Total hardness: Calculated in U.S. Geol. Survey analyses, and includes hardness of all polyvalent cations reported; determined by titration with standard soap solution in Newlands Sanitary Laboratory and Connecticut State Dept. Health a jalyses.

Alkalinity: Determined by acid titration using methyl orange indicator in Newlands Sanitary Laboratory and Connecticut State Dept. Health analyses.

Analyst: U, U.S. Geol. Survey; N, Newlands Sanitary Laboratory, Hartford, Conn.; S, Connecticut State Dept. Health, Hartford, Conn. Citherwise as noted in Remarks column.

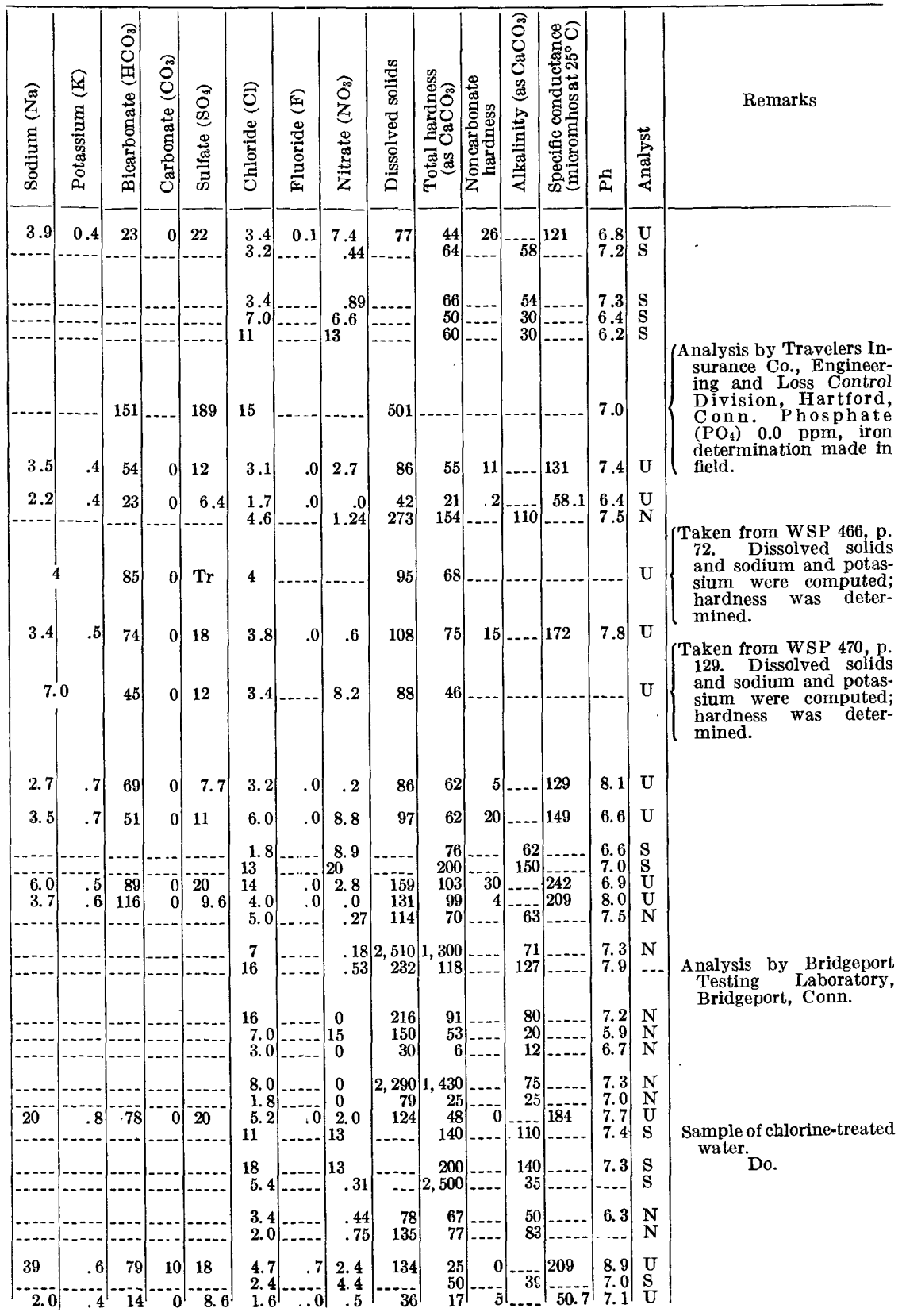


TABLE 13.-Chemical analyses of water from wells and

\begin{tabular}{|c|c|c|c|c|c|c|c|c|c|c|c|}
\hline $\begin{array}{l}\text { Well } \\
\text { No. }\end{array}$ & Location & 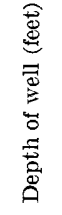 & 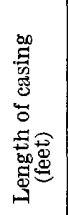 & Water-yielding unit & $\begin{array}{l}\text { Date of } \\
\text { collection }\end{array}$ & 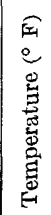 & 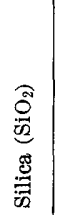 & 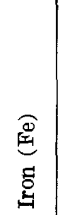 & 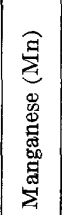 & 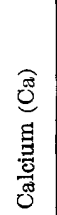 & 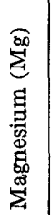 \\
\hline Gr 85 & H8-3aа-- & 187 & 92 & Newark gr & Aug. 16, 1955 & & & & & & \\
\hline $\begin{array}{l}\text { Gr } 90 \ldots \\
\text { Gr } 91 \ldots\end{array}$ & $\begin{array}{l}\text { H8-3df-- } \\
\mathrm{H} 8-3 \mathrm{dh}\end{array}$ & $\begin{array}{r}66 \\
270\end{array}$ & $\begin{array}{l}63 \\
85\end{array}$ & $\begin{array}{l}\text { Valley-train deposits } \\
\text { Newark group..... }\end{array}$ & $\begin{array}{ll}\text { Jan. } & 2,1956 \\
\text { May } 16,1951\end{array}$ & 52 & 12 & .05 & .00 & 43 & 2.2 \\
\hline Gr $97 \ldots$ & $\mathrm{H} 9-7 \mathrm{bg}$ & 107 & 35 & Hartland forma- & Nov. 7,1955 & & & & & & \\
\hline Gr 105a & H8-2jf & $15 \pm$ & $\cdots-\cdot$ & Alluvial deposits (?). & July 16,1954 & & & 1.2 & 1.2 & & \\
\hline Gr 108 & H8-2jb.- & 42 & 381,2 & Ice-contact deposits & Mar. 24, 1947 & & & 6.5 & & & \\
\hline Gr 113.. & H8-3aаa-- & 123 & $\begin{array}{r}56 \\
140\end{array}$ & Newark group, & June 18,1954 & 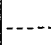 & & & & & 0 \\
\hline Si $37 \ldots$ & H8-9bg & $\begin{array}{r}140 \\
50\end{array}$ & $\begin{array}{r}140 \\
38\end{array}$ & Ire-contact deposits & $\begin{array}{l}\text { May 8, } 1956 \\
\text { Nov. } 16,1954\end{array}$ & $\cdots$ & 7.8 & $<.13$ & 60 & 8.1 & .0 \\
\hline Si $39 \ldots$ & $\mathrm{H} 7-2 \mathrm{jb}$ & 313 & 34 & Newark group, s..... & 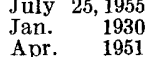 & 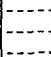 & $\cdots$ & & $\ldots$ & & \\
\hline $\begin{array}{l}\text { Si } 51 a_{-.} \\
\text {Si } 59 a_{-.}\end{array}$ & $\mathrm{H7}$ & 632 & 166 & & Sept. 8,1954 & & & & & & \\
\hline $159 a_{\ldots-}$ & 118-7ga -- & 301 & 10 & Hartland formation - & Jan. 1,1956 & 51 & 12 & .79 & .16 & 8.5 & 9 \\
\hline $\begin{array}{l}\text { Si } 75 \ldots . . \\
\text { Si } 78 \ldots\end{array}$ & $\begin{array}{l}\text { H77-1hd - } \\
\text { H7-5ac- }\end{array}$ & $\begin{array}{l}55 \\
270\end{array}$ & $\begin{array}{c}52 \\
135 \pm\end{array}$ & $\begin{array}{l}\text { Ice-contact deposits. } \\
\text { Newark group, s.... }\end{array}$ & $\begin{array}{lr}\text { Jan. } & 2,1956 \\
\text { June } & 17,1949\end{array}$ & 50 & $\begin{array}{c}12 \\
--\end{array}$ & $\begin{array}{l}10 \\
0.1\end{array}$ & .01 & 3.4 & 1.5 \\
\hline Si $81 \ldots$ & $\mathrm{H} 7-1 \mathrm{fa} .$. & $73 \frac{1}{2}$ & 66 & Ice-contact deposits. - & Oct. 26,1955 & 49 & 10 & .01 & .06 & 11 & 1.3 \\
\hline $\begin{array}{l}\text { Si } 82 .- \\
\text { Si } 84\end{array}$ & H8-8gc-- & $\begin{array}{l}275 \\
105\end{array}$ & & New: & Dec. 2,1955 & & & .40 & $-\cdots$ & & \\
\hline & H8-7hg & $100 \pm$ & $60 \pm$ & Newark group, s....- & Jan. $\quad 5.1956$ & {$[-1$} & & -..- & 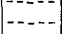 & & \\
\hline$S 19$ & H7-2bd. & $156 \pm$ & $\begin{array}{l}20 \pm \\
30 \pm\end{array}$ & 烈 & Aug. 23,1955 & & & & & & \\
\hline \multirow{4}{*}{$\begin{array}{l}\text { Si } 98 \\
\text { Si 102.. } \\
\text { Si 1 108... } \\
\text { Si 3sp... }\end{array}$} & H8-7dg . & 112 & 11 & Hartla & Feb & & & 1.1 & & & \\
\hline & $\begin{array}{l}\text { H7-4ce-. } \\
\text { H7-1cg. }\end{array}$ & $\begin{array}{r}125 \\
60\end{array}$ & 11 & $\begin{array}{l}\text { Newa } \\
\text { Iee-co }\end{array}$ & $\begin{array}{l}\text { Oct. } 17,1955 \\
\text { Jan } 30.1953\end{array}$ & -- & & 2 & $|\ldots|$ & & $\cdots$ \\
\hline & H8-8fe.. & & & Ice-contact deposits? & May 25,1954 & & & $<.1$ & & & \\
\hline & & & & & Nov. 29,1954 & & & .1 & & & \\
\hline
\end{tabular}


springs in the Farmington-(yranby area-Continued

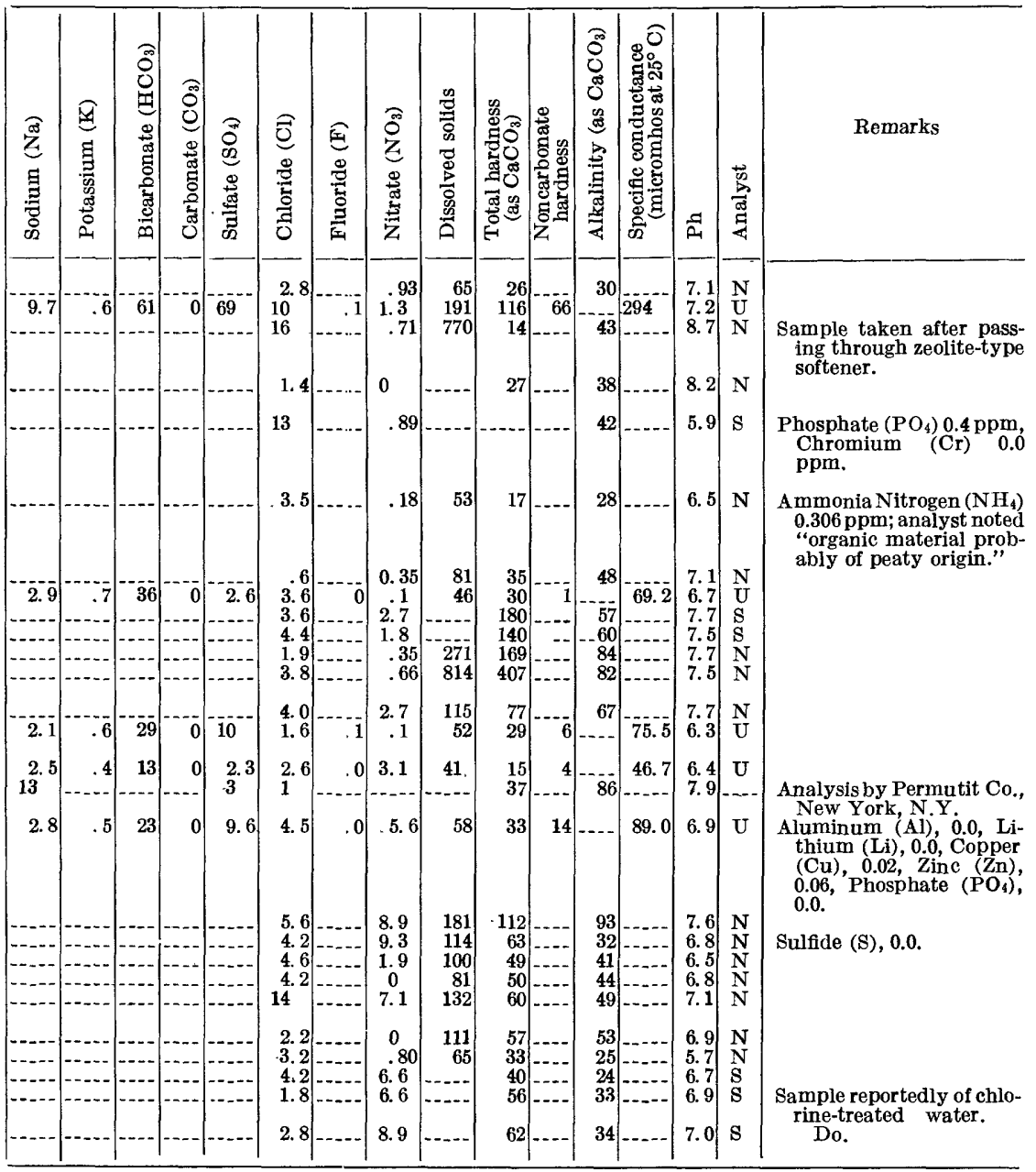




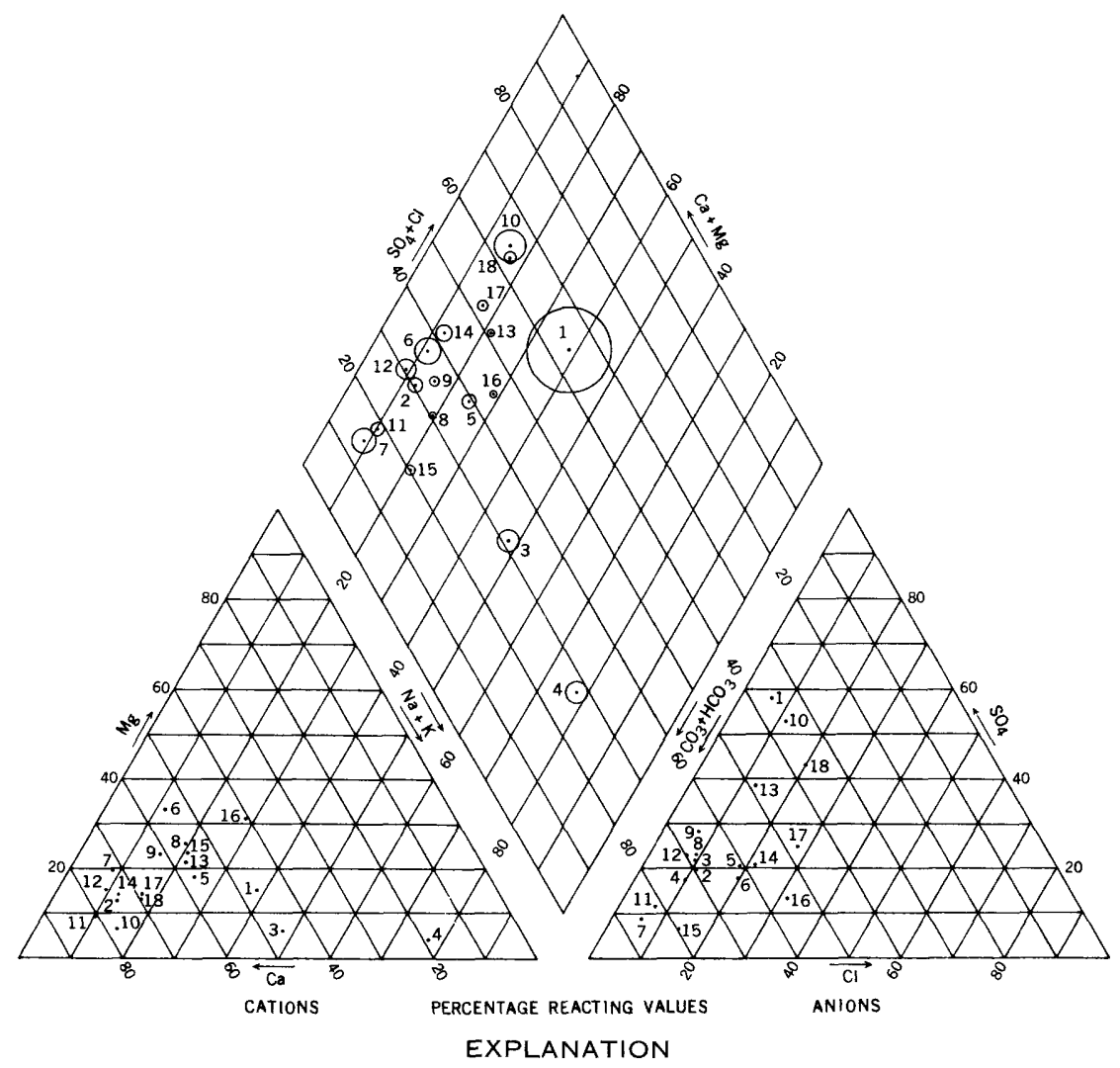

Size of circle indicates concentration in parts per million, thus:

$$
\begin{aligned}
& \text { Scale of diameters } \\
& 0.500 \\
& \text { Scale of radii }
\end{aligned}
$$

\begin{tabular}{|c|c|c|c|c|c|c|c|c|c|}
\hline 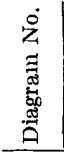 & $\begin{array}{l}\text { Well } \\
\text { No. }\end{array}$ & $\begin{array}{r}\text { depth } \\
\text { (feet) }\end{array}$ & 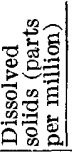 & $\begin{array}{l}\text { Water-yielding } \\
\text { unit }\end{array}$ & 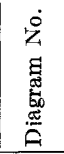 & $\begin{array}{l}\text { Well } \\
\text { No. }\end{array}$ & $\left|\begin{array}{c}\text { depth } \\
\text { (feet) }\end{array}\right|$ & 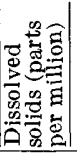 & $\begin{array}{l}\text { Water-yielding } \\
\text { unit }\end{array}$ \\
\hline $\begin{array}{l}1 \ldots \\
2 \ldots \\
3 \ldots \ldots \\
4 \ldots \\
5 \ldots \\
6 \ldots \\
8 \ldots \\
9 \ldots \\
10 \ldots \\
11 \ldots\end{array}$ & $\begin{array}{l}\text { A39 } \\
\text { A } 62 \\
\text { F } 78 \\
\text { Gr } 26 \\
\text { EG } 9 \\
\text { F } 16 \\
\text { F } 20 \\
\text { A } 68 \\
\text { Si } 59 a \\
\text { Gr } 90 \\
\text { F } 3\end{array}$ & $\begin{array}{r}140 \\
87 \\
438 \\
328 \\
118 \\
55 \\
353 \\
101 \\
301 \\
66 \\
120\end{array}$ & $\begin{array}{r}501 \\
86 \\
124 \\
134 \\
88 \\
159 \\
131 \\
42 \\
52 \\
191 \\
86\end{array}$ & $\begin{array}{l}\text { Newark group, } \\
\text { sedimentary rock. } \\
\text { Newark group. } \\
\text { Collinsville gneiss. } \\
\text { Hartland formation. } \\
\text { Valley-train } \\
\text { deposits. }\end{array}$ & $\begin{array}{l}13 \ldots \\
14 \ldots \\
15 \ldots- \\
16-\ldots \\
17 \ldots-\ldots \\
18 \ldots \ldots\end{array}$ & $\begin{array}{l}\text { A } 81 \\
\\
\text { Gr } 82 \mathrm{a} \\
\text { F } 6 \\
\text { Gr } 145 \\
\text { Si } 75 \\
\text { Si } 81 \\
\text { A } 20\end{array}$ & $\begin{array}{c}82 \\
\\
\\
531 / 2 \\
37 \\
140 \\
55 \\
731 / 2 \\
24\end{array}$ & $\begin{array}{l}108 \\
\\
\\
\\
36 \\
97 \\
46 \\
41 \\
58 \\
77\end{array}$ & $\begin{array}{l}\text { Ice-contact deposits } \\
\text { (high percentage } \\
\text { of Triassic } \\
\text { detritus). } \\
\text { Ice-contact deposits. }\end{array}$ \\
\hline
\end{tabular}

FIfURE 17.-Diagrammatic representation of the chemical character of ground water in the FarmingtonGranby area 
Water from crystalline bedrock generally has a lower content of dissolved solids than water from the Newark group and is similar in composition to water from most stratified glacial deposits. It is, however, more likely to contain an excessive amount of iron. Only four analyses of water from crystalline bedrock were obtained for this report, but analyses published in older reports on central Connecticut (Palmer, 1920, p. 62-64; 1921, p. 64-65) show similar conditions.

Most water from the stratified drift, like that from crystalline bedrock, has a relatively small mineral content and a $\mathrm{pH}$ of 7.0 or lower. The high proportion of crystalline detritus in most of the stratified deposits may explain this similarity. However, water from wells A 81 and Si 37, which tap ice-contact deposits containing abundant detrital fragments of Triassic siltstone and shale, has a relatively large mineral content and a $\mathrm{pH}$ greater than 7.0. Well $\mathrm{Gr} 90$ also yields water of higher mineral content than most other wells in stratified drift; however, it is only a few hundred feet from the edge of the layer of trap rock which caps Manitook Mountain, and the high mineral content may be due in part to downward movement of water from the trap rock into the stratified drift.

Excessive quantities of iron and manganese were found in samples from 3 out of 16 wells finished in stratified drift. During field investigation it was learned that most of the wells that tap stratified drift along the southwest shore of Manitook Lake in Granby, and many of those along other parts of the lake shore and also just south of the lake, reportedly yield water excessively high in iron. Wells in icecontact deposits some distance from the shore reportedly do not have this problem; neither do local bedrock wells, although some wells in the Newark group elsewhere in the Farmington-Granby area do yield water high in iron. The high iron content in the ground water in this locality seems to be geographically associated with the lake and possibly may result from dissolving of iron from the sediments by acids derived from organic material accumulating in the lake. The ground water probably moves southwestward in this locality toward Salmon Brook, the main stream, which explains the greater severity of the problem on the southwest shore of the lake. A well on the shore of a pond along Canton Read in Granby is also reported to yield water high in iron, and similar conditions may occur close to other lakes, ponds, and swamps in the Farmington-Granby area, many of which may also contain an excess of organic material.

\section{QUALTTY AS IT INFLUENCES USE}

The major chemical constituents of ground water in the Farmington-Granby area are listed in table 14, and the significance or effects of 
each are summarized. Where maximum or minimum limits have been recommended for public and private drinking and culinary waters, such limits are quoted. Also listed are the range of concentration and other significant features of the occurrence of each constituent in the ground water in the Farmington-Granby area, as determined from analyses in this report. Iron plus manganese, and nitrate, are the only constituents that fairly commonly exceed the recommended limits for drinking and culinary uses. Also, some water is so low in hardness as to be potentially corrosive.

Water used in many industrial processes and for irrigation must also meet specific requirements as to concentrations of mineral constituents, which in some respects are more stringent than those for drinking and culinary water supplies. Moore (1940) provides information on the water-quality requirements of a number of industries, as well as for such uses as boiler feed and air conditioning. Wilcox (1948) discusses quality requirements for irrigation water.

\section{BACTERIAL CONTAMINATION IN GROUND WATER}

Bacteria and other organic matter may be present locally in ground water. Proper location and construction of a well are essential if the water pumped from it is to be free from harmful bacteria and safe for human consumption.

Connecticut law requires that a well be no closer than 75 feet from a privy, leaching field, or other sewage disposal system (Connecticut State Dept. of Health, 1948). A greater distance should be allowed if possible, particularly where wells are finished at shallow depth in localities where the water table is very near the surface and little opportunity is afforded for contaminated water to be filtered naturally before reaching the water table and beginning to move laterally. Also, if possible, a well should be located so that the direction of natural ground-water movement is not toward the well from a source of contamination. In the Farmington-Granby area, ground water generally flows toward the nearest stream, in the same direction as the general slope of the land surface.

Dug wells should be constructed with a tight, solid cover, to prevent foreign objects from falling into the well, and with impermeable casing above the water table, to ensure that water from the land surface near the well must percolate a maximum distance before entering the well.

Drilled wells finished in bedrock are commonly believed to be safe from contamination. This belief is justified, however, only if the unconsolidated deposits above bedrock are sufficiently thick so that any sewage effluent or other contamination is purified before it reaches 
TaBLE 14.-Signifucance, recommended limits, and concentration of various constituents in ground water in the Farmington-Granby area.

\begin{tabular}{|c|c|}
\hline Constituent & $\begin{array}{c}\text { Significance; recommended limits for } \\
\text { domestic and public supplies }\end{array}$ \\
\hline Silica $\left(\mathrm{SiO}_{2}\right)_{\ldots}$ & $\begin{array}{l}\text { Forms hard scale in pipes and } \\
\text { boilers; inhibits deteriora- } \\
\text { tion of zeolite-type water } \\
\text { softeners. }\end{array}$ \\
\hline $\begin{array}{l}\text { Iron }(\mathrm{Fe}) \text { and } \\
\text { manganese } \\
(\mathrm{Mn})\end{array}$ & $\begin{array}{l}\text { U.S. Public Health Service } \\
\text { (1946) recommends that } \\
\text { iron and manganese to- } \\
\text { gether should not exceed } 0.3 \\
\text { ppm. More than } 0.3 \mathrm{ppm} \\
\text { strains laundry and utensils } \\
\text { reddish brown (iron) to } \\
\text { brown black (manganese) } \\
\text { and is objectionable for food } \\
\text { proces i ng, beverages. } \\
\text { Larger quantities impart } \\
\text { taste, favor growth of iron } \\
\text { bacteria. }\end{array}$ \\
\hline $\begin{array}{l}\text { Calcium }(\mathrm{Ca}) \\
\text { and magne- } \\
\text { sium }(\mathrm{Mg}) \text {. }\end{array}$ & $\begin{array}{l}\text { Responsible for most of the } \\
\text { hardness and scale-forming } \\
\text { properties of water; soap } \\
\text { consuming. U.S. Public } \\
\text { Health Service (1946) rec- } \\
\text { ommends that magnesium } \\
\text { should not exceed } 125 \text { ppm. }\end{array}$ \\
\hline $\begin{array}{l}\text { Sodium }(\mathrm{Na}) \\
\text { and potas- } \\
\text { sium }(\mathrm{K}) .\end{array}$ & $\begin{array}{l}\text { In large amounts cause foam- } \\
\text { ing in boilers and other } \\
\text { difficulties in special water } \\
\text { uses. }\end{array}$ \\
\hline $\begin{array}{l}\text { Bicarbonate } \\
\left(\mathrm{HCO}_{3}\right) \text { and } \\
\text { carbonate } \\
\left(\mathrm{CO}_{3}\right)\end{array}$ & $\begin{array}{l}\text { In combination with calcium } \\
\text { and magnesium forms car- } \\
\text { bonate hardness; decom- } \\
\text { poses when heated, forming } \\
\text { scale and releasing cormo- } \\
\text { sive } \mathrm{CO}_{2} \text { gas. }\end{array}$ \\
\hline Sulfate $\left(\mathrm{SO}_{4}\right)_{-}$ & $\begin{array}{l}\text { Sulfates of calcium and mag- } \\
\text { nesiam form a hard scale. } \\
\text { U.S. Public Health Service } \\
\text { (1946) recommends that } \\
\text { sulfate should not exceed } \\
250 \mathrm{ppm} \text {. }\end{array}$ \\
\hline
\end{tabular}

Concentrations in ground water in the Farmington-Granby area 1

A range of 7.8 to $25 \mathrm{ppm}$ was recorded; 7 samples from rocks of the Newark group ranged in silica content from 12 to $25 \mathrm{ppm}$, median 16 ppm; 9 samples from stratified drift ranged from 7.8 to $14 \mathrm{ppm}$, median $12 \mathrm{ppm}$.

A range of 0.01 to $6.5 \mathrm{ppm}$ was recorded. Twenty-four wells yielded water having less than $0.3 \mathrm{ppm}$ iron plus manganese, 10 . wells yielded water having more than 0.3 ppm. The only 3 samples from crystalline rock analyzed for iron and manganese had $1.1,0.95$, and $0.25 \mathrm{ppm}$. Water from many wells finished in ice-contact deposits along and just south of Manitook Lake in Granby contains excessive amounts of iron, and similar conditions may occur in the immediate vicinity of some other lakes and swamps.

Most of the samples tested for magnesium contained only 1 to $3 \mathrm{ppm}$, none more than 12 $\mathrm{ppm}$. Calcium concentration ranged from 3.4 to 63 $\mathrm{ppm}$, median $16 \mathrm{ppm}$.

Most of the samples analyzed for sodium and potassium contained 2.6 to $7.0 \mathrm{ppm}$ of these two constituents, none more than $40 \mathrm{ppm}$.

The range in concentration of bicarbonate in samples analyzed for these constituents was 13 to $151 \mathrm{ppm;} \mathrm{only}$ well Gr 26 yielded water containing carbonate.

Most of the samples tested for sulfate contained 2 to 20 ppm, none more than 189 ppm.

See footnote at end of table. 
Table 14.-Significance, recommended limits, and concentration of various constituents in ground water in the Farmington-Granby area-Continued

\begin{tabular}{|c|c|c|}
\hline Constituent & $\begin{array}{l}\text { Significance; reconmmended limits for } \\
\text { domestic and public supplies }\end{array}$ & $\begin{array}{l}\text { Concentrations in ground water in the } \\
\text { Farmington-Granby area }\end{array}$ \\
\hline Chloride (Cl) & $\begin{array}{l}\text { Imparts taste to water; objec- } \\
\text { tionable for somespecialized } \\
\text { industrial uses. The U.S. } \\
\text { Public Health Service }(1946) \\
\text { recommends that chloride } \\
\text { should not exceed } 250 \text { ppm. }\end{array}$ & $\begin{array}{l}\text { None of the samples tested for } \\
\text { chloride contained more than } \\
18 \text { ppm. }\end{array}$ \\
\hline Fluoride $(\mathrm{F}) \ldots$ & $\begin{array}{l}\text { In water consumed by children, } \\
\text { about } 0.7 \text { ppm or more re- } \\
\text { duces incidence of tooth de- } \\
\text { cay; } 1.5 \text { ppm or more may } \\
\text { cause mottling of tooth } \\
\text { enamel (Lohr and Love, } \\
\text { 1954). }\end{array}$ & $\begin{array}{l}\text { Water from well Gr } 26 \text { con- } \\
\text { tained } 0.7 \text { ppm of flouride; } \\
\text { all other samples contained } \\
0.0 \text { or } 0.1 \text { ppm. }\end{array}$ \\
\hline Nitrate $\left(\mathrm{NO}_{3}\right)_{--}$ & $\begin{array}{l}\text { Some nitrates are formed by } \\
\text { the oxidation and purifica- } \\
\text { tion of decayed organic mat- } \\
\text { ter; hence, values greater } \\
\text { than } 1.0 \text { ppm (New York } \\
\text { State Dept. of Health, 1947) } \\
\text { or greater than the local av- } \\
\text { erage (Pree and others, 1957, } \\
\text { p. 47) may reflect pollution. } \\
\text { There is some evidence that } \\
\text { more than } 44 \text { ppm may cause } \\
\text { methemoglobinemia, or } \\
\text { "blue babies" (Maxcy, 1950) }\end{array}$ & $\begin{array}{l}\text { Samples from } 52 \text { wells were } \\
\text { tested for nitrate; none was } \\
\text { found in } 9 \text {, while the largest } \\
\text { concentration was } 20 \text { ppm. } \\
\text { Of the } 52 \text { wells, } 28 \text { contained } \\
\text { water with less than } 1.0 \text { ppm } \\
\text { nitrate, } 24 \text { had more than } \\
1.0 \text { ppm. None of } 4 \text { wells } \\
\text { in crystalline bedrock (all on } \\
\text { sparsely settled, unfarmed } \\
\text { land) yielded water with } \\
\text { more than } 0.1 \text { ppm nitrate, } \\
\text { and large values were some- } \\
\text { what less common in the } \\
\text { Newark group than in the } \\
\text { stratified drift. }\end{array}$ \\
\hline $\begin{array}{c}\text { Dissolved } \\
\text { solids. }\end{array}$ & $\begin{array}{l}\text { The U.S. Public Health Serv- } \\
\text { ice (1946) suggests that } \\
\text { total dissolved solids should } \\
\text { not exceed } 500 \text { ppm for } \\
\text { water of good chemical } \\
\text { quality, but } 1,000 \text { ppm may } \\
\text { be permitted; however, } \\
\text { people can become accus- } \\
\text { tomed to water with } 2,000 \\
\text { ppm with no ill effects, and } \\
\text { a few public water supplies } \\
\text { in the United States have } \\
\text { even greater dissolved solids } \\
\text { contents. }\end{array}$ & $\begin{array}{l}\text { Samples from } 42 \text { wells were } \\
\text { analyzed for total solids; } \\
\text { only } 3 \text { contained more than } \\
501 \text { ppm, and } 1 \text { of these con- } \\
\text { tained less than } 1,000 \text { ppm. } \\
\text { These } 3 \text {, plus another whose } \\
2,500 \text { ppm hardness suggests } \\
\text { a similar total solids level, are } \\
\text { all from wells on or near the } \\
\text { Talcott Mountain trap ridge. } \\
\text { (All four analyses are partial, } \\
\text { so that the maximum con- } \\
\text { centrations mentioned above } \\
\text { for most individual minerals } \\
\text { do not include these sam- } \\
\text { ples.) Water from rocks of } \\
\text { the Newark group and from } \\
\text { stratified drift high in Trias- } \\
\text { sic detritus generally con- } \\
\text { tains more total solids than } \\
\text { water from crystalline rock } \\
\text { and the rest of the stratified } \\
\text { drift. }\end{array}$ \\
\hline
\end{tabular}

See footnote at end of table. 
TABLE 14.-Significance, recommended limits, and concentration of various constituents in ground water in the Farmington-Granby area-Continued

\begin{tabular}{|c|c|c|}
\hline Constituent & $\begin{array}{l}\text { Significance; recommended limits for } \\
\text { domestic and public supplies }\end{array}$ & $\begin{array}{c}\text { Concentrations in ground water in the } \\
\text { Farmington-Granby area }\end{array}$ \\
\hline Hardness _ _ & $\begin{array}{l}\text { A measure of the effect of } \\
\text { various mineral constitu- } \\
\text { ents, especially calcium and } \\
\text { magnesium. The New } \\
\text { York State Dept. of Health } \\
\text { (1947) states that water } \\
\text { softer than } 50 \text { ppm is cor- } \\
\text { rosive, water from 50 to } \\
150 \text { ppm in hardness is } \\
\text { desirable to passable, while } \\
\text { water of more than } 150 \\
\text { ppm is undesirable owing } \\
\text { to increased soap consump- } \\
\text { tion and scale formation. }\end{array}$ & $\begin{array}{l}\text { Water softer than } 50 \mathrm{ppm} \text { was } \\
\text { found in } 23 \text { wells, water } \\
\text { between } 50 \text { and } 150 \mathrm{ppm} \text { in } \\
\text { hardness in } 21 \text { wells, and } \\
\text { water harder than } 150 \mathrm{ppm} \\
\text { in } 8 \text { wells. Water from the } \\
\text { Newark group and from } \\
\text { stratified drift high in Trias- } \\
\text { sic detritus is generally hard- } \\
\text { er than water from crystal- } \\
\text { line bedrock and the rest of } \\
\text { the stratified drift. }\end{array}$ \\
\hline Alkalinity & $\begin{array}{l}\text { A measure of corrosiveness; } \\
\text { the New York State Dept. } \\
\text { of Health (1947) states that } \\
\text { the alkalinity of water pass- } \\
\text { ing through iron distribu- } \\
\text { tion systems should be in } \\
\text { the range of } 30 \text { to } 100 \text { ppm } \\
\text { to prevent serious corro- } \\
\text { sion. }\end{array}$ & $\begin{array}{l}\text { A range of } 12 \text { to } 150 \mathrm{ppm} \text { was } \\
\text { recorded from } 36 \text { wells. } \\
\text { Water of more than } 100 \mathrm{ppm} \\
\text { alkalinity was found only in } \\
4 \text { deep wells in rocks of the } \\
\text { Newark group along or east } \\
\text { of the Talcott Mountain } \\
\text { ridge. Alkalinity is near or } \\
\text { below } 30 \text { ppm in most water } \\
\text { from stratified drift, except } \\
\text { stratified drift high in Tri- } \\
\text { assic detritus. }\end{array}$ \\
\hline $\begin{array}{l}\text { pH (Hydrogen } \\
\text { ion concen- } \\
\text { tration). }\end{array}$ & $\begin{array}{l}\text { pH values below } 7.0 \text { indicate } \\
\text { acid characteristics, above } \\
\text { 7.0, aklaline characteristics. } \\
\text { Water becomes increasingly } \\
\text { corrosive as the pH de- } \\
\text { creases below 7.0. The } \\
\text { New York State Dept. of } \\
\text { Health (1947) states that } \\
\text { pH values of } 5.0 \text { to } 8.5 \text { are } \\
\text { acceptable except from the } \\
\text { standpoint of corrosion. }\end{array}$ & $\begin{array}{l}\text { A range of } 5.7 \text { to } 8.9 \text { was re- } \\
\text { corded, with most values } \\
\text { between } 6.3 \text { and } 7.9 \text {. The } \\
\text { pH of most water from rocks } \\
\text { of the Newark group is } 7.0 \\
\text { or higher. The pH of most } \\
\text { water from stratified drift } \\
\text { is } 7.0 \text { or lower, except for } \\
\text { water from stratified drift } \\
\text { high in Triassic detritus. }\end{array}$ \\
\hline $\begin{array}{l}\text { Specific con- } \\
\text { ductance. }\end{array}$ & $\begin{array}{l}\text { A measure of the ability of } \\
\text { water to conduct electricity, } \\
\text { which varies in proportion } \\
\text { to the concentration and } \\
\text { degree of ionization of the } \\
\text { dissolved constituents. }\end{array}$ & $\begin{array}{l}\text { A range of } 46.7 \text { to } 294 \mathrm{mi}- \\
\text { cromhos, at } 25^{\circ} \mathrm{C} \text {, was found } \\
\text { among the samples tested. }\end{array}$ \\
\hline
\end{tabular}

1 Based on chemical analyses recorded in table 13.

the rock, for if contaminated water once enters the rock it may move downward and laterally for a considerable distance before becoming purified. In an area where only 10 to 20 feet of unconsolidated material overlies the rock, a well is safest if the casing is set 20 to 30 feet or more below the rock surface and tightly sealed, preferably cemented. The potential hazard is particularly high in heavily settled areas where the homes have individual wells and septic tanks; accordingly, if extensive home construction is planned in an area where there is 
only a thin mantle of unconsolidated deposits, public sewage disposal or water supply should be considered.

It is wise to have the water from a domestic well analyzed occasionally. A baeteriological analysis will reveal any current contamination; a chemrical analysis will show increases in the concentrations of chlorides and nitrogen compounds and warn of possible future contamination.

\section{TEMPERATURE OF GROUND WATER}

The average temperature of ground water in the zone tapped by most water wells in the Farmington-Granby area is nearly the same as the mean annual air temperature at Hartford, $50.1^{\circ} \mathrm{F}$. (See table 2.) Ground water close to the land surface undergoes seasonal temperature fluctuations of several degrees, owing principally to differences in the temperature of the water that infiltrates to the zone of saturation during the different seasons of the year. These fluctuations become smaller with depth. Water from a well that depends on induced recharge from a stream or lake for part of its supply is likely to vary widely in temperature, because of the large seasonal variations in temperature of the surface water. At depths of more than 60 feet, seasonal fluctuations in water temperature are small to nonexistent; however, the average temperature of ground water increases $1^{\circ} \mathrm{F}$. for about every 64 feet of depth, corresponding to the increase in the earth's temperature with depth, and thus wells that obtain alf their supply from depths of several hundred feet are likely to yield water a few degrees warmer than that obtained from shallower wells.

Monthly water-temperature measurements have been made since April 30, 1957, in several observation wells, and spot readings were taken in other wells during this investigation. Temperatures of $42^{\circ}$ to $60^{\circ} \mathrm{F}$. have been recorded in dug wells and springs, although readings above $55^{\circ} \mathrm{F}$. have been uncommon and occurred mostly after unusually heavy rains in early autumn. In drilled wells, temperatures of $45^{\circ}$ to $55^{\circ} \mathrm{F}$. have been recorded. (Two higher readings were taken during the summer in unused wells where water was standing only a few feet below the land surface.) In most drilled wells the range of fluctuation has been no more than $3^{\circ}$.

A graph of periodic temperature measurements in three wells, two of which were dug wells tapping till and the third a drilled well tapping the Newark group (fig. 18), illustrates the greater seasonal temperature fluctuations in the shallower ground water. It may be noted that changes in water temperature lag behind changes in air temperature; for example, the warmest months in Connecticut are July and August, yet this graph shows that highest ground-water temperatures occur principally in September and October. 


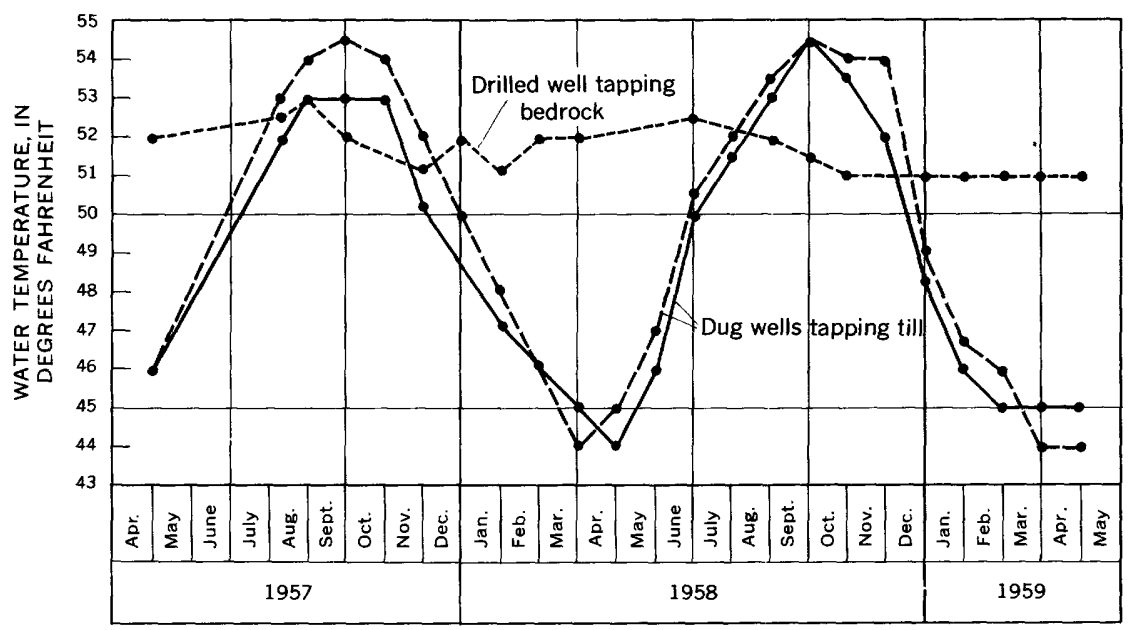

EXPLANATION

EG 32, depth 21 feet

Si $1 \overline{22}$, depth 18 feet

$F 7$, depth 101 feet

Temperature measurements

FIgUre 18.-Fluctuations of ground-water temperatures. Complete records of these three wells appear in table 11 .

\section{LOGS OF WELLS AND TEST BORINGS}

Logs of 37 wells and test borings in the Farmington-Granby area, all specifically referred to in the text, are given on the following pages. They are arranged alphabetically by towns and consecutively by well numbers within each town. Preceding each $\log$ is the following information as available: well number, location, name of owner, name of drilling contractor, date drilled, altitude, and type of log.

The well-location system used in this report is described on pages 7-8). The altitude of the land surface at each location was estimated from the topographic map, with the exception of several foundation test borings by the Connecticut State Highway Department where the altitude had been determined by spirit leveling.

Logs referred to as sample-study logs were prepared from examination of well cuttings by the writer. Drillers' logs were copied from written reports or records of drillers, or were obtained by talking to drillers during or immediately after the drilling operation. Logs 
originally prepared in narrative style by drillers were rearranged by the writer, and are referred to as modified drillers' logs. Drillers' logs provided by the Connecticut State Highway Department are in most cases based upon laboratory study of samples by State Highway Department engineers as well as upon the original drillers' descriptions. Reported logs are those quoted from memory by drillers some time after the wells were completed, or-by owners, builders, or other individuals.

Stratigraphic correlations are by the writer.

TABLE 15.-Detailed logs of wells and test borings in the Farmington-Granby area

- Material $\mid$\begin{tabular}{c} 
Thick- $\begin{array}{c}\text { ness } \\
\text { (feet) }\end{array}$ \\
(feet) \\
\hline
\end{tabular}

Town of Avon

A 56 H7-5ha

[Louis Delbone Estate. Drilled by Dick's Artesian Well Co. in 1948. Alt $170 \mathrm{ft}$. Driller's and reported $\log ]$

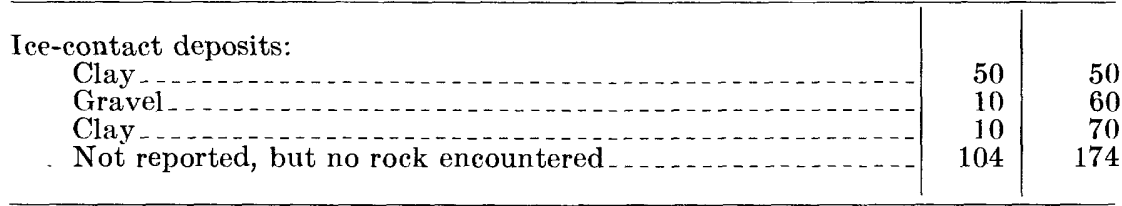

Note.-Well backfilled with gravel to about $100 \mathrm{ft}$; whether final casing depth is $100 \pm \mathrm{ft}$ or $174 \mathrm{ft}$ is not certain.

$$
\text { A } 62 \quad \mathrm{H} 7-4 \mathrm{ja}
$$

[J. J. Maher. Drilled by Louis Allyn \& Sons in 1953. Alt $260 \mathrm{ft}$. Driller's log]

\begin{tabular}{l|r|r}
\hline Ice-contact deposits: & \\
$\quad \begin{array}{r}\text { Sand and gravel, yellow and red } \\
\text { Ground-moraine deposits: }\end{array}$ & 17 \\
$\quad$ Hardpan _ Newark group, sedimentary rock: & 82 \\
$\quad$ Red rock__. & 87
\end{tabular}


TABLE 15.-Detailed logs of wells and test borings in the Farmington-Granby area-Continued

\begin{tabular}{rl|c|c}
\hline Material & $\cdot$ & $\begin{array}{c}\text { Thick- } \\
\text { ness } \\
\text { (feet) }\end{array}$ & $\begin{array}{c}\text { Depth } \\
\text { (feet) }\end{array}$ \\
\hline
\end{tabular}

\section{Town of Avon-Continued}

\section{A 108 G7-6hf}

[Howard E. Carlson. Drilled by State-Line Well Drilling in 1956. Alt $300 \mathrm{ft}$. Sample-study log]

Ice-contact deposits:

Sand, yellow-brown, poorly sorted; grains range from granule gravel to silt; very fine sand and silt 15 to 20 percent, coarser grains coated with silt; almost all crystalline material

Sand, yellow-brown to brownish, medium and coarse above to medium below, moderately sorted; very fine sand and silt $5 \pm$ percent. Almost no Triassic shale-siltstone grains; red-stained grains much less common than un-

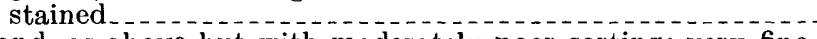

Sand, as above but with moderately poor sorting; very fine sand and silt 10 to 15 percent . . . . . . . . . . . . . .

Sand, fine, moderately well-sorted; Triassic content same as from 15 to $40 \mathrm{ft}$

Sand, brown, somewhat micaceous, very fine and fine, moderately sorted; some medium sand and considerable silt...

Silt, red-brown; about 10 to 15 percent coarser grains; very little clay

Sand, pale-brownish-white, medium and coarse, moderately poor sorting; about 10 percent very fine sand and silt; no silt coatings on grains; red-stained grains much less common than unstained

Sand, coarse and very coarse; sorting moderate; some medium sand and granule gravel and less than 5 percent very fine sand and silt

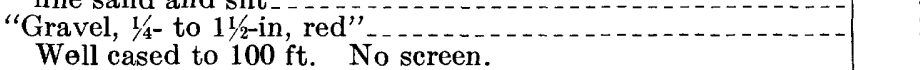

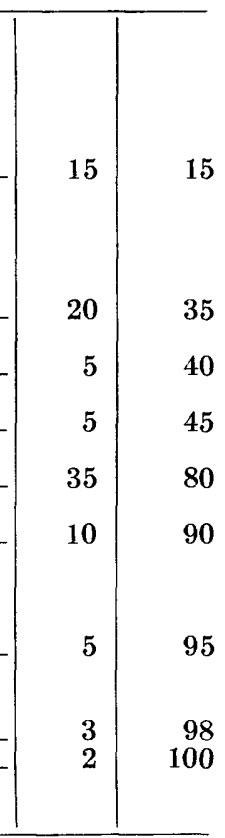

\section{A 109 G7-9ab}

[Ernest Hudon. Drilled by John F. Sima in 1956. Alt. 455 ft. Driller's log.]

Ground-moraine deposits:

Hardpan, gravel and boulders

Collinsville gneiss of Rodgers and others (1956):

Decayed rock

NOTE.-Well cased to $100 \mathrm{ft}$. 
TABLE 15.-Detailed logs of wells and test borings in the Farmington-Granby area-Continued

\begin{tabular}{c|c|c}
\hline Material & $\begin{array}{c}\text { Thick- } \\
\text { ness } \\
\text { (feet) }\end{array}$ & $\begin{array}{c}\text { Depth } \\
\text { (feet) }\end{array}$ \\
\hline
\end{tabular}

\section{Town of Avon-Continued}

\section{A $114 \quad$ H7-4hd}

[Catholic Church. (Arch Road). Drilled by Capitol Well Drilling in 1956. Alt. $305 \mathrm{ft}$. Driller's and sample-study log.]

Ice-contact deposits:

-Sand, pale-pink to orange; well could probably have been finished in it.

Silt, red

Sand, pale-pink to orange, came up into pipe often; well could Ground-moraine deposits:

probably have been finished in it

Hardpan

Newark group, sedimentary rock:

Red rock

\begin{tabular}{r|r} 
& \\
55 & 55 \\
5 & 60 \\
27 & 87 \\
3 & 90 \\
134 & 224 \\
\hline
\end{tabular}

Nore.-Two samples, collected at random from pile of cuttings when drilling was at $90 \mathrm{ft}$, consisted of sand, mostly medium and coarse, moderately well to well-sorted; fine sand about 10 percent, silt 1 to 5 percent; very few Triassic shale and siltstone grains, but many grains had slight red stain or coating; grains subangular to subrounded.

\section{A $129 \quad$ G7 -9 fg}

[Balph Tallmadge. Drilled by Gene Genest in 1953. Alt. $270 \mathrm{ft.}$ Reported log.]

Ice-contact deposits:

Gravel. (Owner had bored a 15-ft. hole, reported mostly fine sand.) (O.

Clay

Gravel

Newark group, sedimentary rock:

Shale rock

\begin{tabular}{|r|r} 
& \\
70 & 70 \\
20 & 90 \\
10 & 100 \\
93 & 193 \\
\hline
\end{tabular}

Nore.-Thicknesses quoted above are appreximate; the depth to rock is believed correct within $\pm 5 \mathrm{ft}$.

\section{Town of East Granby}

\section{EG 27 H8-9cd}

[Test boring. Drilled by Connecticut State Highway Department. Alt. $142.06 \mathrm{ft}$ (leveled). Driller's log.]

Alluvial deposits:

Muck; organic silt

Ice-contact or alluvial deposits:

Gravel (under 2-in), sand, silt; red-brown.

Ground-moraine deposits:

Gravel, sand, silt, cobbles: hardpan, with clay. Boulder from $13 \frac{1}{2}$ to $141 / 2 \mathrm{ft} \ldots$

Newark group, sedimentary rock:

Red rock, soft

Red rock; core recovered

\begin{tabular}{l|r}
$61 / 2$ & $61 / 2$ \\
3 & $91 / 2$ \\
& \\
$51 / 2$ & 15 \\
3 & 18 \\
2 & 20 \\
\end{tabular}


TABLE 15.-Detailed logs of wells and test borings in the Farmington-Granby area-Continued

\begin{tabular}{|c|c|c|}
\hline Material & $\begin{array}{c}\text { Thick- } \\
\text { ness } \\
\text { (feet) }\end{array}$ & $\begin{array}{l}\text { Depth } \\
\text { (feet) }\end{array}$ \\
\hline
\end{tabular}

\section{Town of East Granby-Continued}

\section{EG 38 H8-6eh}

[Bogoslofski. Drilled by Capitol Well Drilling in 1955. Alt. $190 \mathrm{ft}$. Driller's log.]

Valley-train deposits:

Sand, coarse, and gravel

Sand, fine, gray -

Newark group, sedimentary rock:

Red rock

\begin{tabular}{|r|r}
10 & 10 \\
82 & 92 \\
133 & 225 \\
\hline
\end{tabular}

\section{Town of Farmington}

F 67 H6-3ed

[John T. Ryan. Drilled by Rizza \& Cassilino in 1954. Alt. 345 ft. Reported log.]

\begin{tabular}{l|r|r}
\hline Drumlin deposits: & & \\
$\quad$ Hardpan & 100 & 100 \\
N ewark group: & 5 & 105 \\
$\quad$ Gray rock, soft & 10 & 115 \\
Trap rock, & \\
Brownstone & & 207 \\
\hline
\end{tabular}

F 74 H6-3df

[Eckert. Drilled by V. Leone \& Son in 1955 . Alt $325 \mathrm{ft}$. Driller's log]

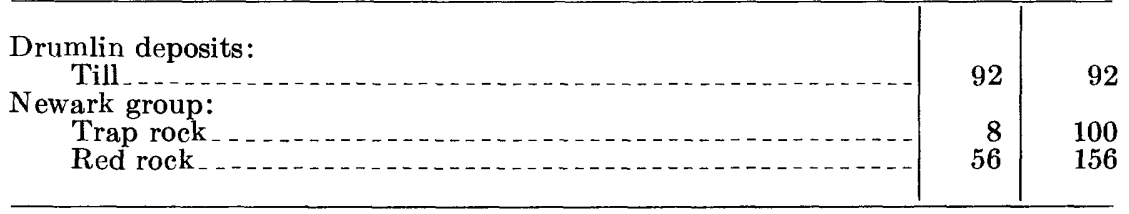

\section{F $79 \quad$ H6-4be}

[U.S. Army (Missile site). Drilled by Louis Allyn \& Sons in 1955 . Alt $205 \mathrm{ft}$. Driller's and samplestudy log]

Valley-train deposits:

Sand, medium and coarse, brownish-yellow

Ice-contact deposits:

Quicksand, watery

Clay, sandy, gray (a sample reported to be from this layer consisted of gray, slightly clayey silt)

Clay, sandy, brownish-red

Ice-contact deposits or older deposits:

Gravel, yielded lots of water; could have finished a well in this

Ground moraine deposits:

Hardpan, red

N ewark group, sedimentary rock:

Red shale, hard and sof $\mathrm{t}$

Red sandstone

Red rock.

\begin{tabular}{r|r}
40 & 40 \\
35 & 75 \\
25 & 100 \\
90 & 190 \\
20 & 210 \\
119 & 329 \\
51 & 380 \\
10 & 390 \\
171 & 561 \\
&
\end{tabular}


TABLE 15.-Detailed logs of wells and test borings in the Farmington-Granby area-Continued

\begin{tabular}{ll|c} 
Material & $\begin{array}{c}\text { Thick- } \\
\text { ness } \\
\text { (feet) }\end{array}$ & $\begin{array}{c}\text { Depth } \\
\text { (feet) }\end{array}$ \\
\hline
\end{tabular}

Town of Farmington-Continued

F $80 \quad$ H6-1af

[Joseph Lorencik. Drilled by Harold Hutteman in 1955. Alt $215 \mathrm{ft}$. Driller's log]

- Ice-contact deposits:

Gravel, red, with considerable clay; drilled $24 \mathrm{ft}$ ahead of

casing at one point without caving

Sand, clay, and gravel

Sand, not much water

Clay (?)

Sand, lots of water; could have finished a well in this

Newark group, sedimentary rock:

Red rock.

\begin{tabular}{|r|r} 
& \\
& \\
30 & 30 \\
25 & 55 \\
4 & 59 \\
4 & 63 \\
4 & 67 \\
293 & 360 \\
\hline
\end{tabular}

\section{F 98c G7-9jh}

[Unionville Water Co. Drilled by Caisson Wells, Inc. in 1952. Alt $193 \mathrm{ft}$. Modified driller's log]

Alluvial deposits:

Sand and stones

Alluvial deposits(?):

Gravel, white. (Set screen at $31 \mathrm{ft}$ and completed well.)

Ice-contact deposits :

Sand, fine to coarse, red. (Set screen, developed with compressed air, but too much sand came in.)

Newark group:

Rock, at.

\begin{tabular}{rr|r}
9 & 9 \\
21 & 30 \\
& \\
11 & 41 \\
$-\ldots$ & 41 \\
\hline
\end{tabular}

\section{F $100 \quad \mathrm{H} 6-1 \mathrm{bg}$}

[Unionville Water Co. Drilled by Caisson Wells, Ine. in 1952. Alt $180 \mathrm{ft}$. Driller'g ing]

Alluvial deposits:

Sand and stone

Alluvial deposits(?):

Sand and gravel, whit

Ice-contact deposits:

Sand and gravel, red. (Set $9 \frac{1}{2} \mathrm{ft}$ of screen at $56 \mathrm{ft}$ and completed well.)

\begin{tabular}{r|r}
9 & 9 \\
11 & 20 \\
46 & 66 \\
\hline
\end{tabular}


TABLE 15.-Detailed logs of wells and test borings in the Farmington-Granby area-Continued

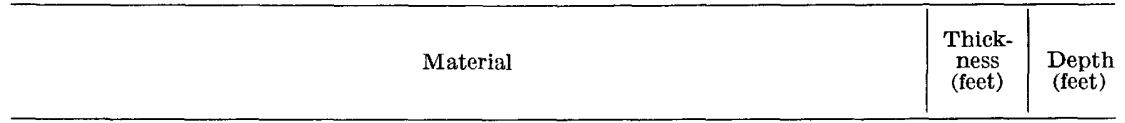

Town of Farmington-Continued

F 105 H6-4be

[Gerald LaMontagne. Drilled by Joseph Stack in 1956 . Alt. $205 \mathrm{ft}$. Sample-study and driller's log]

Valley-train deposits:

"Sand"

"Gravel-smaller than pea gravel"

Ice-contact deposits:

"Quicksand, gray, very fine"

"Gray clay" (Sample from about $180 \mathrm{ft}$. consists of silt, much of it fine silt, plus a little clay, gray-brown in color.) "Grades downward into-"

"Red clay"

Silt, red; subordinate very fine sand and almost no clay. Grain size ranges from barely visible at $15 \times$ to $0.1 \mathrm{~mm}$ except for larger mica flakes.

Sand, pale-red, medium to very fine; subordinate silt; moderately sorted. Silt $10 \pm$ percent in $270-\mathrm{ft}$. sample, 2 to 5 percent in $280 \mathrm{ft}$. sample. Triassic shale and siltstone grains 15 percent, all very angular, weak; remainder chiefly white to clear quartz grains, angular to subangular, some stained. Ground-moraine deposits:

Till, red, quite firm and compact. All sand grains coated $w$ ith fines; silt and clay at least 25 percent........... Pre-(or pro-) late glacial sand:

Sand, pale-reddish-brown, chiefly fine and very fine, highly silty, highly micaceous, poorly sorted. Silt about 20 percent, medium and coarse sand less than 5 percent (plus mica flakes). Silt is gray brown

Newark group, sedimentary rock:

"Red rock, quite soft. Fairly hard to seal off sand."

40

45

95

140

$90 \pm 230=$

$25 \pm 255$

10

265

20

285

$15 \pm 300 \pm$

$20 \pm$

\section{F 116 H6-4af}

[American Research Co. Drilled by Michael S. Buczko in 1956. Alt $215 \mathrm{ft}$. Driller's log]

Ice-contact deposits:

Sand, fine, dirty gray in color

100

Sand, fine, grading to red....

Ice-contact or ground-moraine deposits:

Small gravel, red, noted very little water in it

ce-contact deposits or pre-late-glacial sand:

Sand, fine

Newark group, sedimentary rock:

Red rock (sample at 390 to 400 is red silty shale) 
TABLE 15.-Detailed logs of wells and test borings in the Farmington-Gramby area-Continued

\begin{tabular}{c|c|c}
\hline Material & $\begin{array}{c}\text { Thick- } \\
\text { ness } \\
\text { (feet) }\end{array}$ & $\begin{array}{c}\text { Depth } \\
\text { (feet) }\end{array}$ \\
\hline
\end{tabular}

\section{Town of Farmington-Continued}

\section{F 118 H6-4ca}

[Esso Oil Co.... Drilked by Louis Allyn \& Sons in 1956. Alt $175 \mathrm{ft}$. Driller's and sample-study log]

Valley-train deposits:

"Sand, mostly fine, gray"

"Sand, with layers of not too hard gravelly hardpan, gray.

No significant supply of water noted." (Well drilled by rotary rig; when drilling had reached $180 \mathrm{ft}$, the writer observed that the upper part of the first mud pit contained gray medium to very coarse sand; the upper part of the second contained gray medium sand; no gravel and few fines observed.)

Ground-moraine deposits:

"Hardpan, red".

"Probably hardpan, or tight gravel; originally believed to be rock."

Pre- (or pro-) late-glacial stratified deposits:

"Gravel, red, rather tight; some matcrial would stick to bit. Obtained $5 \mathrm{gpm}$ with casing at $227 \mathrm{ft}$, depth of hole uncertain." (Cuttings near top of mud pits were chiefly fine to very fine red sand when drilling had reaehed $247 \mathrm{ft}$.)

\begin{tabular}{|r|r}
$\cdots 100$ & 100 \\
& \\
& \\
80 & 180 \\
15 & 195 \\
33 & 228 \\
& \\
17 & 247 \\
\hline
\end{tabular}

F 120 H6-2dd

[Test boring. Drilled by Connecticut State IIighway Department. Alt 160.6 ft (leveled). Driller's log]

Alluvial deposits:

Topsoil

Topsoil, light-brown, sandy

Sand, fine, and silt; light-brown . . . . . . . . . . . . .

Silt, dark-brown

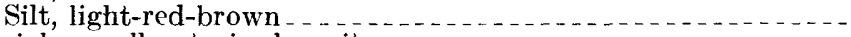

Alluvial or valley-train deposits:

Sand, fine, and silt; gray

Gravel, sand, silt; gray $\ldots \ldots \ldots$

Sand, gray, coarse; layers of gravel

Valley-train deposits:

Sand and silt, gray-brown, in layers. One sample contained 27 percent fine sand,..67 percent silt, 6 percent clay; another contained 45 . percent fine sand, 36 percent silt, 4 percent clay

Sand, fine, and silt; brown; layers of clay

Sand, fine, and silt; brown; layers of medium sand

Sand, fine, and silt; some clay; light-brown .............

Ground-moraine deposits:

Hardpan.

Newark group, sedimentary rock:

Red rock at

2

3

$41 / 2$

$51 / 2$

$71 / 2$

2

13

5

$71 / 2 \quad 251 / 2$

16

\begin{tabular}{r|l}
$91 / 2$ & $741 / 2$
\end{tabular}

$41 / 2 \quad 1151 / 2$

$31 / 2 \quad 119$

119 
Table 15.-Detailed logs of wells and test borings in the Farmington-Granby area-Continued

\begin{tabular}{c|c|c}
\hline Material & $\begin{array}{c}\text { Thick- } \\
\text { ness } \\
\text { (feet) }\end{array}$ & $\begin{array}{c}\text { Depth } \\
\text { (feet) }\end{array}$ \\
\hline
\end{tabular}

\section{Town of Farmington-Continued}

\section{F 122 H6-4aj}

[City of New Britain. Drilled by R. E. Chapman Co. in 1954. Alt $178 \mathrm{ft}$. Driller's log]

Valley-train deposits:

Sand and gravel

Ice-contact deposits:

Clay and sand, fine

Clay, brown.

Clay and sand, fine, brown, silty

Clay, brown

Ice-contact deposits (older unit):

Sand, fine, and gravel

Sand and gravel, traces of clay

Sand, fine, and clay

Ground-moraine deposits(?)

Hardpan and clay

\section{F 123 H6-4aj}

[City of New Britain. Drilled by R. E. Chapman Co. in 1952. Alt $175 \mathrm{ft}$. Driller's log]

Valley-train deposits:

Sand and clay

Ice-contact deposits:

Clay, very soft

Sand and clay

Ice-contact deposits (older unit):

Gravel, water-bearing

Sand, hard-packed.

Sand, fine

Gravel, medium (Set $20 \mathrm{ft}$ of screen at $130 \mathrm{ft}$.)

Sand and clay $\ldots \ldots \ldots$

Newark group, sedimentary rock:

Ledge at

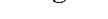

\section{Town of Granby \\ Gr 62 H8-5gd}

[Charles Rice. Drilled by Louis Allyn \& Sons in 1951. Alt $320 \mathrm{ft}$. Reported log]

Ice-contact deposits:

Sand, yellow 
TABLE 15.-Detailed logs of wells and test borings in the Farmington-Granby area-Continued

\begin{tabular}{c|c|c} 
Material & $\begin{array}{c}\text { Thick- } \\
\text { ness } \\
\text { (feet) }\end{array}$ & $\begin{array}{c}\text { Depth } \\
\text { (feet) }\end{array}$ \\
\hline
\end{tabular}

Town of Granby-Continued

Gr 93 H8-2cc

[Harry LeClair. Drilled by Connecticut Valley Artesian Well Co. Inc. in 1955. Alt $255 \mathrm{ft}$. Driller's log]

Ice-contact deposits:

Coarse sand with pebbles and cobbles, dry

Same, becoming more gravelly, heaving somewhat ........

Gravel with water. (Yield tested at $1 \frac{1}{2} \cdot \mathrm{gpm}$ with open-end pipe without clearing end of pipe; could have made a good gravel well, but owner insisted on a rock well.) _.......... Newark group, sedimentary rock:

Red rock. (Well Gr 6 became muddy during this drilling)

\section{Gr 105 H8-2jf}

[Salmon Brook, Coffee Shop. Drilled by Connecticut Valley Artesian Well Co. Inc. in 1954. Alt $188 \mathrm{ft}$. Reported $\log ]$

Ice-contaet deposits (alluvial deposits 0 to $10 \pm$ ?):

Sand, mostly mediumsand coarse; heaved badly, water-

bearing; could have finished well "at almost any depth"... Newark group, sedimentary rock:

Red rock

\section{Gr 106a H8-2je}

[John Lind. Drilled by Connecticut Valley Artesian Well Co. Inc. in 1956. Alt $190 \mathrm{ft.}$ Driller's log]

Ice-contact or valley-train deposits:

Gravel and stones, yellow, coarse

Ice-contact deposits:

Sand, yellow, coarse, loose.

Gravel, medium coarse

Sand, fine, packed

Sand, coarse, fine gravel

Newark group, sedimentary rock:

Rock, red, medium

NOTE.-Driller reports the ice-con tact gravels could have provided a large supply of water, but he drilled through them because he thought the water would be high in iron. 
TABLE 15.-Detailed logs of wells and test borings in the Farmington-Granby area-Continued

\begin{tabular}{c|c|c}
\hline Material & $\begin{array}{c}\text { Thick- } \\
\text { ness } \\
\text { (feet) }\end{array}$ & $\begin{array}{c}\text { Depth } \\
\text { (feet) }\end{array}$ \\
\hline
\end{tabular}

Town of Granby-Continued

Gr 131 H8-5bf

[William Venberg. Drilled by State-Line Well Drilling in 1956. Alt $230 \mathrm{ft}$. Sample-study log]

Ice-contact deposits:

Sand, mostly medium and coarse but poorly sorted, ranging from 5 percent pebbles to 10 to 15 percent very fine sand and silt; grains somewhat dirty. A few red-stained grains. Slight pinkish tinge

Sand, as above but with 10 percent pebbles and $5 \pm$ percent very fine sand and silt

Sand, similar to above, mostly medium and fine; sorting moderate; very fine sand and silt 5 percent or less; grains cleaner

Sand, similar to above, mostly medium, well-sorted, quite clean; about 30 percent red-stained grains . . . . . . . . . . .

Sand, brownish, very fine, containing subordinate fine sand and silt (mostly $1 / 6$ to $1 / 15 \mathrm{~mm}$ ), quite micaceous; sorting moderate to good. Silt $25 \pm$ percent in $60-\mathrm{ft}$ sample

Sand, coarse to very coarse, well-sorted
Sand, slightly pinkish, mostly medium and fine, well-sorted, less than 5 percent very fine sand and silt; 30 percent red-stained grains

Gravel, broken fragments up to $2 \mathrm{~mm}$, dominantly of Triassic sandstone and siltstone; sand 35 percent, similar to above but poorly sorted, 10 percent of which is very fine sand and silt

"Gravel, red and white, loose"

\begin{tabular}{|c|c} 
& \\
& \\
20 & 20 \\
5 & 25 \\
& \\
10 & 35 \\
5 & 40 \\
& \\
23 & 63 \\
$2(?)$ & 65 \\
5 & \\
5 & 70 \\
& \\
5 & 75 \\
5 & 80 \\
\hline
\end{tabular}

\section{Town of Simsbury}

\section{Si 51 H7-5ac}

[Hartford Special Machinery Co. Drilled by S. B. Church Co. in 1953. Alt $185 \mathrm{ft}$. Driller's log]

Valley-train deposits:

Sand, yellow

Clay, gray

Newark group, sedimentary rock:

Sandstone, red

Not reported

\begin{tabular}{r|r} 
& \\
9 & 9 \\
80 & 99 \\
35 & 134 \\
458 & 592 \\
56 & 648
\end{tabular}

\section{Si $51 \mathrm{a} \quad \mathrm{H7}-5 \mathrm{ac}$}

[Hartford Special Machinery Co. Drilled by S. B. Church Co. in 1953. Alt 182 ft. Driller's log]

Valley-train deposits:

Sand, yellow

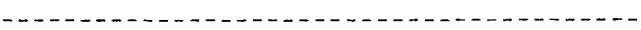

Silt and clay mixed, red

Clay, red ............

Newark group, sedimentary rock:

Rock, red sandstone. 
TABLE 15.-Detailed logs of wells and test borings in the Farmington-Granby area-Continued

\begin{tabular}{c|c|c}
\hline Material & $\begin{array}{c}\text { Thick- } \\
\text { ness } \\
\text { (feet) }\end{array}$ & $\begin{array}{c}\text { Depth } \\
\text { (feet) }\end{array}$ \\
\hline
\end{tabular}

\section{Town of Simsbury-Continued}

Si 81 H7-1fa

[Village Water Co. Drilled by R. E. Chapman Co. in 1954. Alt $245 \mathrm{ft.} \mathrm{Driller's} \mathrm{log]}$

Ice-contact deposits:

Sand, fine.

Sand, coarse

Sand, fine, dirty

Sand, water-bearing. (Set $7 \% \mathrm{ft}$ of 60 -slot Everdur sereen at $73^{1 / 6} \mathrm{ft}$ )

Newark group, sedimentary rock:

Ledge

\begin{tabular}{r|r}
15 & 15 \\
15 & 30 \\
35 & 65 \\
9 & 74 \\
& \\
\hline & at 74
\end{tabular}

Si 81d H7-1fa

[Village Water Co. Drilled by R. E. Chapman Co, in 1954 . Alt $245 \mathrm{ft}$. Driller's log]

Ice-contact deposits:

Sand and gravel

Sand and fine gravel

Sand, medium

Sand, medium

Sand, fine

\begin{tabular}{|c|c|c|}
\hline $\begin{array}{c}\text { Si } 84 \text { H8-9ag } \\
\text { [Cullman Brothers, Inc. Drilled by S. B. Church Co. in 1955. Alt } 185 \mathrm{ft} \text {. I }\end{array}$ & Driller's log] & \\
\hline $\begin{array}{l}\text { Vallev-train deposits: } \\
\text { Sand. } \\
\text { Silt and fine sand } \\
\text { Ice-contact deposits(?): } \\
\text { Sand, good, coarse } \\
\text { Sand, good. }\end{array}$ & $\begin{array}{l}12 \\
61 \\
\\
27 \\
10\end{array}$ & $\begin{array}{r}12 \\
73 \\
100 \\
110\end{array}$ \\
\hline
\end{tabular}

Note.-Casing 16-in diameter; 36-in gravel pack; 60-slot screen 88 to $105 \mathrm{ft}$.

Si $100 \quad$ H7-1he

[Leonard Goodchild. Drilled by Connecticut Valley Artesian Well Co. Inc. in 1956. Alt $290 \mathrm{ft}$. Driller's $\log$ ]

Ice-contact deposits:

Sand, coarse, yellow

Sand, mediun, yellow

Gravel, medium, yellow

Gravel, medium, very clean 
T'ABLE 15.-Detailed logs of wells and test borings in the Farmington-Granby area-Continued

\begin{tabular}{c|c|c}
\hline Material & $\begin{array}{c}\text { Thick- } \\
\text { ness } \\
\text { (feet) }\end{array}$ & $\begin{array}{c}\text { Depth } \\
\text { (feet) }\end{array}$ \\
\hline
\end{tabular}

\section{Town of Simsbury-Continued}

Si $103 \quad \mathrm{H} 8-8 \mathrm{jb}$

[Village Water Co. Drilled by Layne-New York Co. Inc. in 1953. Alt. $170 \mathrm{ft.}$ Driller's log]

\begin{tabular}{l|r|r}
\hline Topsoil & & 1 \\
Valley-train deposits: & 1 \\
Sand, medium, red. & 17 \\
Sand, fine, red. & 18 \\
Sand, fine, red; and clay & 44 \\
Sand, fine, red, hardpacked. & 48 \\
\end{tabular}

\section{Si 104 H7-2ce}

[Village Water Co. Drilled by Layne-New York Co. Inc. in 1953. Alt. $155 \mathrm{ft}$. Driller's log]

Valley-train deposits:

Sand, medium, red.

Sand, fine, red

Sand, fine, red; and clay

Silt

Clay and silt

Silt.

\begin{tabular}{|r|r} 
& \\
22 & \\
26 & 22 \\
2 & 48 \\
16 & 50 \\
3 & 66 \\
14 & 69 \\
& 83 \\
\hline
\end{tabular}

Si $105 \quad \mathrm{H} 8-1 \mathrm{jh}$

[Village Water Co. Drilled by Layne-New York Co. Inc. in 1953. Alt. $160 \mathrm{ft}$. Driller's log]

Valley-train deposits:

Sand, medium, brown

Sand, fine, red; and silt

Clay and silt.

Sand, fine, red, silty

Clay and silt.

Silt

Ground-moraine deposits:

Hardpan

\begin{tabular}{r|r} 
& \\
19 & 19 \\
24 & 43 \\
2 & 45 \\
24 & 69 \\
3 & 71 \\
16 & 87 \\
- & 90 \\
3 &
\end{tabular}

Si $109 \quad \mathrm{H} 7-2 \mathrm{fe}$

[Village Water Co. Drilled by Layne-New York Co. Inc. in 1953. Alt. $172 \mathrm{ft}$. Driller's log]

\begin{tabular}{r|r|r}
\hline Topsoil & 2 & 2 \\
Valley-train deposits: & 26 & 28 \\
Sand, fine, brown; and gravel & 2 \\
Clay & 30 \\
Silt & 50 & 80 \\
\hline
\end{tabular}


TAmE 15.-Detailed logs of wells and test borings in the Farmington-Granby area-Continued

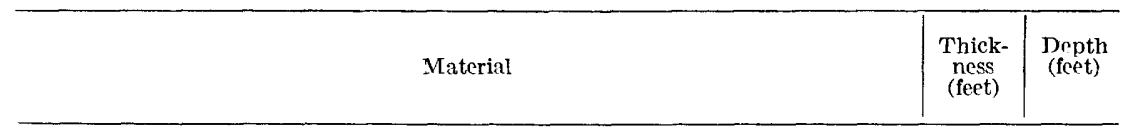

\section{Town of Simsbury-Continued}

\section{Si $128 \quad$ H7-2ej}

Test horing. Drilled by Connecticut State Highway Denartment. Alt $1.53 .50 \mathrm{ft}$ (levele(l). Driller's log. This boring locatect on the east bank of the Farmington River. Borings were marle on the opposite bank to about the same depths, and penetrated similar materials]

Alluvial deposits:

Topsoil

Sand, medium to coarse

Sand, silt wood chips and decayed material

Alluvial or vallev-train deposits:

Sand, medium to coarse; and silt

Vallev-train deposits:

Silt, brown; and very fine sand.

Silt, brown; with layers of clay

\begin{tabular}{c|c} 
& \\
$11 / 2$ & $11 / 2$ \\
10 & $111 / 2$ \\
8 & $191 / 2$ \\
6 & $251 / 2$ \\
20 & $451 / 2$ \\
$1401 / 2$ & 186 \\
\hline
\end{tabular}

Si $129 \quad$ H $7-2 \mathrm{fg}$

[Test horing. 1)rillerl by Connecticut State IIighway Department. Alt, 150.8 ft (leveled). Driller's log]

Alluvial deposits:

Topsoil, silt, sand

Organic silt, black and brown,

Organic silt, black and brown, with grass roots, soft........

Vallev-train deposits:

and, wood chips, pignuts

Sand, very fine, brown; and silt

Silt, brown and gray; and layers of clay

Sand, very fine; and silt

\begin{tabular}{|c|c} 
& \\
3 & 3 \\
5 & 8 \\
$91 / 2$ & $171 / 2$ \\
& \\
$221 / 2$ & 40 \\
145 & 185 \\
67 & 252 \\
\hline
\end{tabular}




\begin{tabular}{|c|c|c|c|c|c|c|c|}
\hline 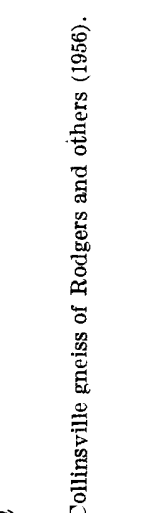 & 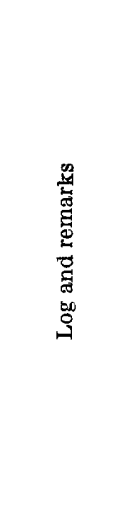 & 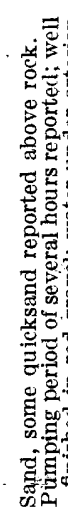 & 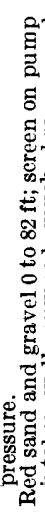 & 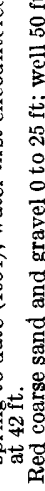 & 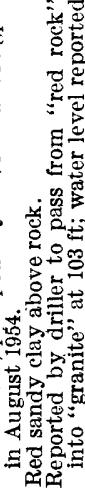 & 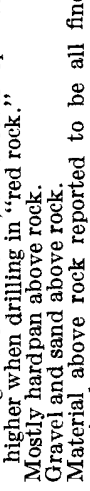 & \\
\hline 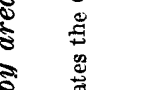 & 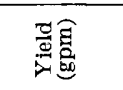 & 䞸。 & $\stackrel{\infty}{0}$ & & ర్లా & $\infty_{\infty}$ & $\infty$ \\
\hline 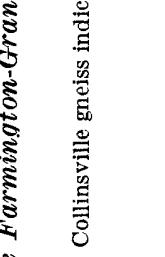 & 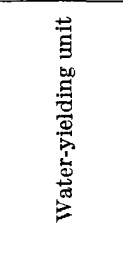 & 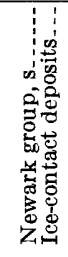 & 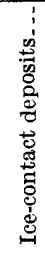 & 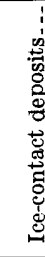 & 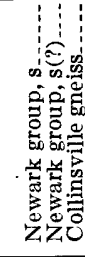 & 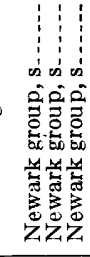 & 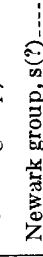 \\
\hline 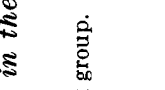 & 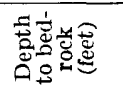 & & & & 蔡品 & H్ & \\
\hline 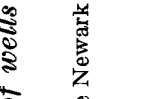 & 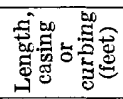 & 必 & வ్ & ผ & 产仝 & 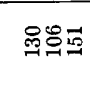 & \\
\hline 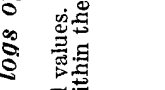 & 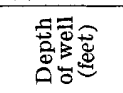 & వైన & ద్ & เू & జู้น & 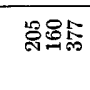 & 筁 \\
\hline 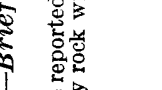 & 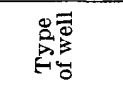 & 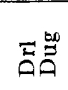 & $\bar{G}$ & $\stackrel{b}{3}$ & EE & EEE & $\vec{E}$ \\
\hline 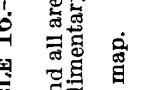 & 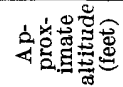 & 고유 & 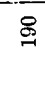 & $\cong$ & $\underset{\substack{\infty \\
\infty}}{\mathbb{\infty}}$ & 옥오요 & జి \\
\hline 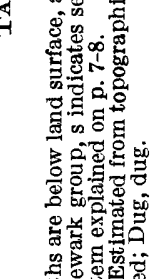 & あ్ & 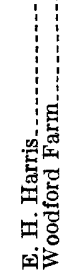 & 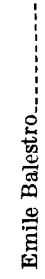 & 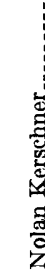 & 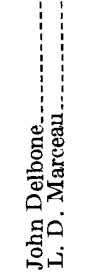 & 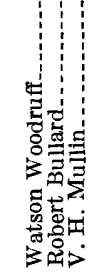 & 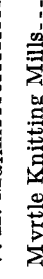 \\
\hline 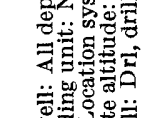 & 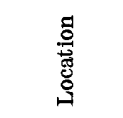 & 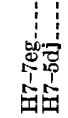 & 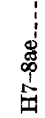 & 至 & 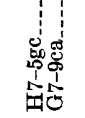 & 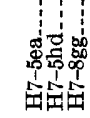 & 告 \\
\hline 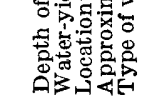 & $\begin{array}{l}\text { कें } \\
\text { 阝ेz }\end{array}$ & $\begin{array}{l}9 \\
\text { 9 } \\
4\end{array}$ & $\begin{array}{l}\text { N } \\
\mathbb{4}\end{array}$ & 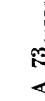 & $\begin{array}{l}28 \\
28 \\
44\end{array}$ & 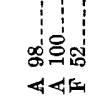 & 5 \\
\hline
\end{tabular}




\section{SELECTED REFERENCES}

Barrell, Joseph, 1915, Central Connecticut in the geologic past: Connecticut Geol. Nat. History Survey Bull. 23, 44 p.

Brown. J. S., 1928, Ground water in the New Haven area, Connecticut : U.S. Geol. Survey Water-Supply Paper 540, 206 p.

Brown, R. H., 1953, selected procedures for analyzing aquifer test data: Jour. Am. Water Works Assoc., v. 45, p. 844-866.

Colbert, E. H., 1946, Hypsognathus, a Triassic reptile from New Jersey : Am. Mus. Nat. History Bull., v. 86, p. 225-274.

Connecticut Ground Water Survey, 1938, Ground-water levels in north-central Comecticut: Comecticut Ground Water Survey Bull. GW-6, 212 p.

Connecticut Public Utilities Commission, 1959, Forty-seventh annual report: Hartford, Conn., published by the State, 295 p. [Covers data for calendar year 1957.]

Connecticut State Department of Health, 1948, Private water supplies, fourth edition : Connecticut State Dept. of Health, 28 p.

1957, Estimated populations as of July 1, 1957 : Weekly Health Bull., v. 39 , no. 13,3 p.

Cushman, R. V., Allen, W. B., and Pree, H. L., Jr., 1953, Geologic factors affecting the yield of rock wells in southern New England: New England Water Works Assoc. Jour., v. 67, no. 2, p. 77-95.

Davis. W. M., 1898, The Triassic formation of Connecticut : U.S. Geol. Surver 18th Ann. Rept., pt. 2, p. 1-192.

Fllis. E. E., 1909, A study of the occurrence of water in crystalline rocks, in Gregory, H. E., Underground water resources of Connecticut: U.S. Geol. Survey Water-Supply Paper 232, p. 54-103.

Enerson, B. K., 1892, unpublished manuscript cited by Weeks, F. B., 1902. North American Geologic Formation Names: U.S. Geol. Survey Bull. 191.

Fenneman, N. M., 1938, Physiography of eastern United States: New York. McGraw-Hill Book Co., 714 p.

Flint, R. F., 1930, The glacial geology of Connecticut: Connecticut Geol. Nat. History Survey Bull. 47, 294 p.

1934, Late glacial features of the Quinnipiac-Farmington lowland in Connecticut : Am. Jour. Sci., v. 227, p. 81-91.

1947, Glacial geology and the Pleistocene epoch: New York, John Wiley and Sons, $589 \mathrm{p}$.

1953, Probable Wisconsin substages and late Wisconsin events in northeastern United States and southeastern Canada: Geol. Soc. America Bull., v. 64, p. 897-919.

Gates, R. M., 1951, The bedrock geology of the Litchfleld quadrangle: Connerticut Geol. Nat. History Survey Misc. Ser., no. 3, 13 p., map.

1954 , The bedrock geolog $y$ of the Woodbury quadrangle: Connecticut Geol. Nat. History Survey Quad. Rejt., no. 3, 23 p., map.

Gregors, H. E., 1909, Inderground water resources of Connecticut: U.S. Geol. Survey Water-Supply Paper 232, 200 p.

Hartshorn, J. H., 1958, Flowtill in southeastern Massachusetts: Geol. Soc. America Bull., v. 69, p. 477-482.

Heald, M. T., 1956, Cementation of Triassic arkoses in Connecticut and Massachusetts : Geol. Soc. America Bull., v. 67, p. 1133-1154. 
Krynine, P. D., 1950, Petrology, stratigraphy, and origin of the Triassic sedimentary rocks of Connecticut: Connecticut Geol. Nat. History Survey Bull. $73,247 \mathrm{p}$.

LaSala, A. M., Jr., 1961, Ground-water levels in Connecticut, 1956-59: Connecticnt Water Resources Comm. Bull. 2.

Lohr, E. W., and Love, S. K., 1954, The industrial utility of public water supplies in the United States, 1952, part 1: U.S. Geol. Survey Water-Supply Paper 1299, $639 \mathrm{p}$.

Lougee, R. J., 1938, Physiography of the Quinnipiac-Farmington Lowland in Connecticut: Waterville, Maine, Colby College, Colby Monographs, no. 7, 64 p., 15 pls.

Maxcy, K. F., 1950, Report on the relation of nitrate concentrations in well waters to the occurrence of methemoglobinemia: Natl. Research Council, Bull. Sanitary Eng., p. 265, App. D.

Meinzer, O. E., 1923, Outline of ground-water hydrology, with definitions: U.S. Geol. Survey Water-Supply Paper 494, 71 p.

Meinzer, O. E., and Stearns, N. D., 1929, A Study of ground water in the Pomperaug basin, Connecticut: U.S. Geol. Survey Water-Supply Paper 597-B, p. 73-146.

Moore, E. E., 1940, Progress report of the committee on quality tolerances of waters for industrial uses, Jour. New England Water Works Assoc., v. 54, p. 263.

New York State Department of Health, 1947, Normal range in the concentration of constituents of potable water: mimeog. release dated Feb. 20, 1947, issued by Bur. of Water Supply, Div. of Sanitation, New York State Dept. of Health.

Palmer, H. S., 1920, Ground water in the Norwalk, Suffield, and Glastonbury areas, Connecticut: U.S. Geol. Survey Water-Supply Paper 470, 171 p.

1921, Ground water in the Southington-Granby area, Connecticut: U.S. Geol. Survey Water-Supply Paper 466, 219 p.

Piper, A. M., 1944, A graphic procedure in the geochemical interpretation of water analyses: Am. Geophys, Union Trans., pt. 6, p. 914-923.

Pree, H. L., Jr., Walker, W. H., and MacCary, L. M., 1957, Geology and groundwater resources of the Paducah area, Kentucky: U.S. Geol. Survey WaterSupply Paper 1417, 214 p.

Prindle. L. M., and Knopf, E. B., 1932, Geology of the Taconic Quadrangle: Am. Jour. Sci., v. 224, p. 257-302.

Redfield, W. C., 1856, On the relations of the fossil fishes of the sandstone of Connecticut and other Atlantic states to the Liassic and Oolitic periods: Am. Jour. Sci., v. 72, p. 357-363.

Rice, W. N., and Gregory, H. E., 1906, Manual of the geology of Connecticut: Connecticut Geol. Nat. History Survey Bull. 6, 273 p.

Rodgers, John, 1952. Absolute ages of radioactive minerals from the Appalachian region: Am. Jour. Sci., r. 250, p. 411-427.

Rodgers, John, Gates, R. M., Cameron, E. N., and Ross, R. J., 1956, Preliminary geological map of Connecticut: Connecticut Geol. Nat. History Survey Bull. 84, map only.

Theis, C. V., 1935, The relation between the lowering of the piezometric surface and the rate and duration of discharge of a well using ground-water storage : Am. Geophys. Union Trans., v. 16, p. 519-524.

I.S. Department of Commerce, from 1914, Climatological data-New England : U.S. Weather Bur. repts., pub. monthly with ann. summ. 
C.S. Department of Commerce, from 1952, Local climatological data-Hartford, Connecticut: U.S. Weather Bur. repts. pub. monthly with ann. summ. [Similar reports for months prior to Sept. 1949 are entitled "Monthly climatological summary," and for months from Oct. 1949 through Dec. 1951, "Station meteorological summary.']

U.S. Geological Survey, from 1928, Surface water supply of the United States, part 1-A. North Atlantic slope basins Maine to Connecticut: U.S. Geol. Surves Water-Supply Papers pub. annually. [Data for years prior to 1951 published as Part 1, North Atlantic slope basins. Data from FarmingtonGranby area included beginning with summar'y for 1928.]

- from 1954, Water levels and artesian pressures in observation wells in the United States, part 1, northeastern states: U.S. Geol. Survey WaterSupply papers pub. periodically. [Data from Farmington-Granby area included beginning with summary for 1954.]

U.S. Public Health Service, 1946, Public Health Drinking Water Standards: Repr. 2697, Public Health Repts., v. 61, p. 371-384.

Wenzel, L. K., 1942, Methods for determining permeability of water-bearing materials, with special reference to discharging well methods: U.S. Geol. Survey Water-Supply Paper 887, 192 p.

Wheeler, Girard, 1937, The west wall of the New England Triassic lowland: Connecticut Geol. Nat. History Survey Bull. 58, $73 \mathrm{p}$.

Wilcox, L. V., 1948, The quality of water for irrigation use : U.S. Dept. Agriculture Tech. Bull. 962, 40 p. 


\section{INDEX}

[Major references are in italic]

A.

A cknowledgments

Alluvial deposits

areal distribution and thickness.

ground-water availability.

lithology

stratified drift, ground-water availability in

unconsolidated deposits, estimating thickness.

water-yielding properties.

Alluvium

Avon.

wells and test borings, detailed logs

\section{B}

Base flow, relation to total runoff

Bedrock surface.

overlain by till

C

Central Lowland

Chemical quality of ground water. See Quality of ground water.

Climate

Climatological data

Collinsville gneiss

11,12

$14,19,20,46$

See also Crystalline rocks.

Congamond Lakes

Connecticut River lowland

19

Connecticut Water Resources Commission... 2,6,7

Consolidated rocks

Crystalline rocks.

jointing in

physiographic expression.................... 10,21

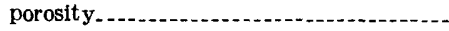

preglacial weathering......................

wells finished in.

Crystalline rocks of pre-Triassic, comparison with other aquifers

depth of wells

distribution and thickness

lithology.

specific capacity of wells.....................

stratographic relations and age

terminology.

water-yielding properties

yields of wells

D

Deglaciation

Delta deposits

Discharge

Domestic or farm supplies, from dug wells in till

Page
Eastorn Highland......

Evapotranspiration, percent of precipitation.- $\quad 76$

Farmington, wells and test borings, detailed logs

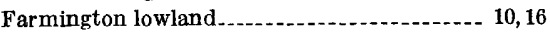

grain size of till........................... 46

Farmington River.................. 10, 18, 19, 58, 75

alluvial deposits, grain size............... 66

deposits beneath alluvium

thickness of alluvium

Farmington Station. . .

Faulting........................... 14, 16

Flowing wells. .

Flowtill ........................................ 48

\section{G}

Geography .

3 Geologic history.............. 14

Geologic units................................ 14

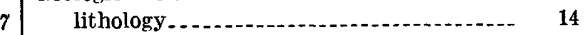

physical characteristics................. 19

subsurface relations........................ 14

water-yielding properties................. 19

Geology -

effect on water-level fluctuations........... 86

Glacial drift_............................. 10, 16

Glacial lake sediments................ 18, 52,60,61

Glacial lakes.................................... 18

Glacial readvance, lack of evidence........... 16

Glaciation 16

Glaciofluvial sediments....................... 52

Gneiss domes............................. 20,21,24

74 Grain size of till.............................. 46

Granby, gneiss domes. .................... 20, 21, 24

48 wells and test borings, detailed logs....... 117 
Page

Gregory, H. E., quoted.

Ground-moraine and drumlin deposits, grain size

lithology

stratigraphic relations

water yielding properties.

Ground-moraine deposits.

distribution and thickness

$14,44,45$

Ground water

occurrence.

temperature

use.

Ground-water constituents, significance, recommended limits and concentration in report area.

H

Hartland formation $14,19,46$ See also Crystalline rocks.

\section{I}

Ice-contact deposits............... 14, 17, 18, 19, 50, 51 areal distribution and thickness..... composition.

facies changes.

grain size and sorting 52,58

lithology 51

permeability

$40,55,58$

screened wells in

size and sorting

stratigraphic relations

water yielding properties..................

Interference, drilled wells in bedrock ...... 33, 88, 90

Intrusive igneous rocks, distribution.

In vestigations, methods

previous.

purpose and scope

Iron in ground water.

\section{$\mathrm{J}$}

Joints, in crystalline rock.

in Newark group

\section{I}

Lava sheets, distribution and thickness

Lithology, alluvial deposits................... Collinsville gneiss

drumlin deposits . . . . . . . . ground-moraine deposits

Hartland formation.

ice-contact deposits

Newark group

valley-train deposits.

M

Manitook Lake, excessive iron in ground water

Manitook Mountain, traprock

Map location system.

Melt-water drainage

Meriden formation
28

15

15

15
103 29

Pot

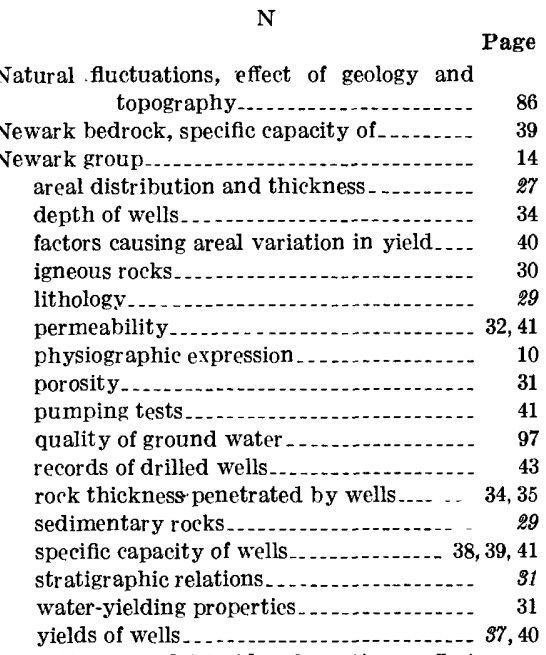

New Haven and Meriden formations, effect on grain size of till.............. 46

New Haven arkose, occurrence and thickness. $\quad 30$

Observation wells, records of . . water-level fluctuation, in Newark group_ $\quad 83$ in unconsolidated deposits _.......... 82

\section{$\mathbf{P}$}

Park River.................. 10

Pequabuck River.

Physiography ................ 8

Pleistocene deposits ...................... 14

Pleistocene gliciation, effects of ........... 10

Population.............. 13

Porosity, Newark group.................. 31

Postglacial history

Potential aquifers . . .......................... 68

Precipitation, Farmington-Granby area ...... 11, 73

relation to runoff_._-_........ 76

Preglacial history ............................... 14

Pre-Triassic rocks.

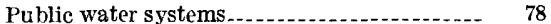

Pumping, effect on water levels

Quality of ground water.................. 96, 104 bacterial contamination in ground water - 104 chemical analyses......................... 98 chemical quality related to source $\ldots . . . . . \quad 97$ concentration of chemical constituents _.-- 105 excessive iron and manganese ........... 103 influences on use..................... 103 significance of chemical constituents.....- 105 typical chemical characteristics........... 96

Quinnipiac water gap, South Meriden....... 18

\section{$\mathbf{R}$}

Recent deposits.

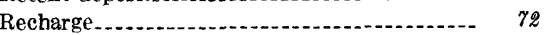

References, selected......................... 124 
River Glen $17,18.53,54,56,61,66$

Roaring Brook valley, ice-contact deposits, grain size.

thickness.

Rodgers, quoted.

\section{S}

Salmon Brook $10,18,58,66,75$

alluvial deposits, grain size thickness.

bedrock valley.

deposits beneath alluvium

Sand bluff

Sand seams.

Simsbury, wells and test borings, detailed $\operatorname{logs}$

Specific capacity of wells, crystalline bedrock.. ice-contact deposits.

Springs, records of

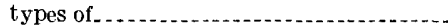

Stratified drift...................... $14,17,18,47,50$ ground-water availability in .............. 68

Stratigraphic relations and age

Stream-gaging stations

Stream terraces

$\mathrm{T}$

Talcott Mountain, depth of wells. quality of ground water 34,87 water levels

Temperature of ground water

Tertiary uplift

Till.

Topography, effect on water-level fuctuations

Trap rocks physiographic expression.

Triassic bedrock, till from

Triassic rocks. See Newark Group.

Trumbull Electr ic Co., Plainville.

Trumbull Electric well, Plainville

\section{U}

Unconsolidated deposits

estimating thickness

U.S. Weather Bureau, climatological data...

Upwarping, postglacial.

Use of groundwater

Valley-train deposits. areal distribution and thickness $14,18,19,50,51,59$ best means for obtaining water lithology overlap of ice-contact deposits stratigraphic relations. units of water-yielding properties

wells finished in.

W

Water gap at Tariff ville

19

Water-level fluctuations.

effects of geology and topography $\ldots$

effects of pumping ....................... 87

maximum range of ..................... 86

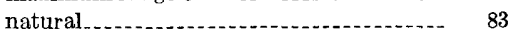

seasonal ................................ 83

un consolidated deposits. ... .

wells in bedrock........................... 87

wells in Newark bedrock. ................ 83

Water-level measurements.................... 3,79

Water levels, in bedrock wells............ $\quad 70$

in wells below drumlins . . . . . . . . . . . . 50,71

long-term trends.................... 85

response to rainfall. .

Water table, depth to

Water-yielding properties.................... 14

alluvial deposits......................... 15

Collinsville gneiss. 15

drumlin deposits........................ 15

ground-moraine deposits_............... $\quad 15$

Hartland formation........................ 15

ice contact deposits....................... 15

Newark group........................... 15

valley-train deposits.................... 15

Weathered bedrock

Well-numbering system......................

Well, A90 .

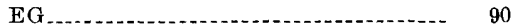

Trumbull Electric Co., Plainville...... 61

Wells, brief logs . . . .

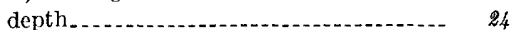

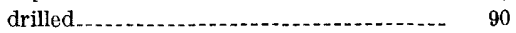

driven

dug

finished in ground-moraine deposits.....- $\quad 49$

finished in ice-contact deposits............ 57

finished in Newark group

finished in valley-train deposits.......... 62

finished with open-end casing .......... 58

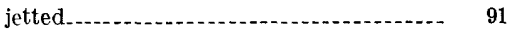

types of .

yields... . . .

Wells and test borings, $\operatorname{logs}$ of . ............ 109

records of $\ldots \ldots \ldots$............................ 6,7

Western Highland............. 8,10

Western upland, importance of alluvium.... 68

Wisconsin stage glaciation ................. 16

\section{$\mathrm{Y}$}

Yields of wells, in crystalline rocks.......... $\quad 25$ in ice-contact deposits................. 56 in Newark group 


\section{Randall, Allan D. 1932-}

Geology and ground water in the Farmington-Granby area, Connecticut. Washington, U.S.. Govt. Print. Off., 1964.

vi, 129 p. illus., maps, diagrs., tables, and portfolio (2 fold. col. maps, diagr.) . $24 \mathrm{~cm}$. (U.S. Geological Survey. Water-supply paper 1661)

Prepared in cooperation with the Connecticut Water Resources Commission.

Bibliography : p.. 124-126.

(.Continued on next card)

Randall, Allan D. 1932- Geology and ground water in the Farmington-Granby area, Connecticut. 1964. (Card 2)

1. Geolog 8 -Connecticut-Hartford Co. 2. Water, UndergroundConnecticut-Hartford Co. 3. Water-supply-Connecticut-Hartford Co. 4. Borings-Connecticut-Hartford Co. I. Connecticut. Water Resources Commission. II. Title: The Farmington-Granby area, Connecticut. (Series) 